\title{
Gathering Souls: Jesuit Missions and Missionaries in Oceania (1668-1945)
}

\author{
Alexandre Coello de la Rosa \\ Universitat Pompeu Fabra, Barcelona, Spain \\ alex.coello@upf.edu
}

\section{1 \\ Introduction*}

The missionary work of the Society of Jesus from 1549 to 1767 should be placed within the context of early modern Iberian expansion, making the Jesuits the first "global religious order." Scholarship has examined the Jesuit missionaries' efforts as a reaction to the global challenges confronted by reformist Catholicism. ${ }^{2}$ When Jerónimo Nadal (1507-80), one of Ignatius of Loyola's (c.1491-1556) closest collaborators, coined the famous phrase totus mundus nostra habitatio fit (the world is our home), he was in fact adapting Zeno of Citium's (334-262 BCE) Stoic principle to claim that Jesuits should not turn their homelands into their world, but the world into their homelands. ${ }^{3}$

* This article forms part of the Research Group on Empires, Metropolises, and Extra-European Societies (GRIMSE), "Dentro y fuera: Cambio institucional e integración social y cultural en el imperio español moderno y contemporáneo, 1550-1950 (una perspectiva comparada de larga duración)," financed by the Ministerio de Economía y Competitividad (FEDER/MINECO), Ref., HAR2015-68183-P, as well as the Research Group on Ethnographies, Cultural Encounters and Religious Missions in the Iberian World (2017-2019) —ECERM (Agència de Gestió d'Ajuts Universitaris i de Recerca (AGAUR), Refa 2017 -SGR-1332).

1 Aliocha Maldavsky, "Jesuits in Ibero-America: Missions and Colonial Societies," in Jesuits and Globalization: Historical Legacies and Contemporary Challenges, ed. Thomas Banchoff and José Casanova (Washington, DC: Georgetown University Press, 2016), 92-110, here 92. On this particular issue, see also Guillermo Wilde, ed., Saberes de la conversión:Jesuitas, indígenas e imperios coloniales en las fronteras de la cristiandad (Buenos Aires: Editorial SB, 2011); Alexandre Coello de la Rosa, Javier Burrieza, and Doris Moreno, eds., Jesuitas e imperios de ultramar (siglos XVI-XX) (Madrid: Sílex, 2012); Paolo Broggio, Evangelizzare il mondo: Le missioni della Compagnia di Gesù tra Europa e America (secoli xvi-xviii) (Roma, Carocci Editore, 2004).

2 Thomas Banchoff and José Casanova, "Introduction," in Banchoff and Casanova, Jesuits and Globalization, 1-13.

3 Anthony Pagden, "Cosmopolitismo, patriotismo, nacionalismo: ¿Qué camino hacia una Europa ilustrada?," Pedralbes 34 (2014): 11-35, here 28. 
Therefore, it should not come as a surprise that their cosmopolitan movement to incorporate new lands into the Catholic world made them "pioneering globalizers." Indeed, their "apostolic mobility" is key to understanding the role of the global mission of the Society of Jesus-imperii propagatio, or Jesuit imperial expansion — and the origins of global modernity in the Iberian colonial empires from the sixteenth to the eighteenth centuries. ${ }^{5}$ It was part of the "way of proceeding" or modo de proceder of the founders, including Loyola himself, Francis Xavier (1506-52), and his successors Alessandro Valignano (1539-1606) and Matteo Ricci $\left(155^{2-1610}\right)$ to extend the Catholic faith everywhere in the Spanish and Portuguese world-usque ad ultimum terrae - and to convert the heathen peoples of East Asia to Catholicism. ${ }^{6}$

From the sixteenth century onward, Western empires organized and transformed colonized areas into fundamentally European constructs, based on the domination of physical space and policies of gathering the native population into grid-plan towns. To control spatial boundaries, colonial discourses elaborated mechanisms of knowledge to count, classify, register, and evangelize the "barbarous others." The idea of Western colonization thus became synonymous with the expansion of what was understood as extending the values of Christian "civilization,"7 beginning in the eighteenth century.

However, as historian Ulrike Strasser has rightly observed, the history of the Marianas provides an intriguing exception to the rule of Spanish colonial expansion and conquest. The impetus for setting up a colonial regime on this chain of fifteen islands came from Jesuits eager to evangelize the archipelago's inhabitants - with no view to making the islands profitable or economically useful for the crown - amid the political and economic crisis of the Spanish monarchy. ${ }^{8}$ When Jesuit Diego Luis de San Vitores (1627-72) arrived at the

4 José Casanova, "The Jesuits through the Prism of Globalization, Globalization through a Jesuit Prism," in Banchoff and Casanova, eds., Jesuits and Globalization, 261-86, here 262.

5 On the origins of modernity in the Catholic world, see Louis Châtellier, "Conclusions," in Missions religieuses modernes: "Notre lieu est le monde," ed. Pierre-Antoine Fabre and Bernard Vincent (Rome: École Française de Rome, 2007), 381-87.

6 Miquel Batllori, Les reformes religioses al segle XVI (Barcelona: Biblioteca d'Estudis d'Investigació, Tres i Quatre, 1996), 4:102.

7 Adriano Prosperi, "L'Europa cristiana e il mondo: Alle origini dell'idea di missione," Dimensioni e problemi della ricerca storica 2 (1992): 189-220, here 192; Joan-Pau Rubiés, "Missionary Encounters in China and Tibet: From Matteo Ricci to Ippolito Desideri," History of Religions 52, no. 3 (2013): 267-82, here 267 .

8 Ulrike Strasser, "Rome to Guam and Back: The Re-formation of Chamorro Identity in a Changing World," Archiv für Reformationsgeschichte/Archive for Reformation History 108, no. 1 (2017): 212-22, here 212 . 


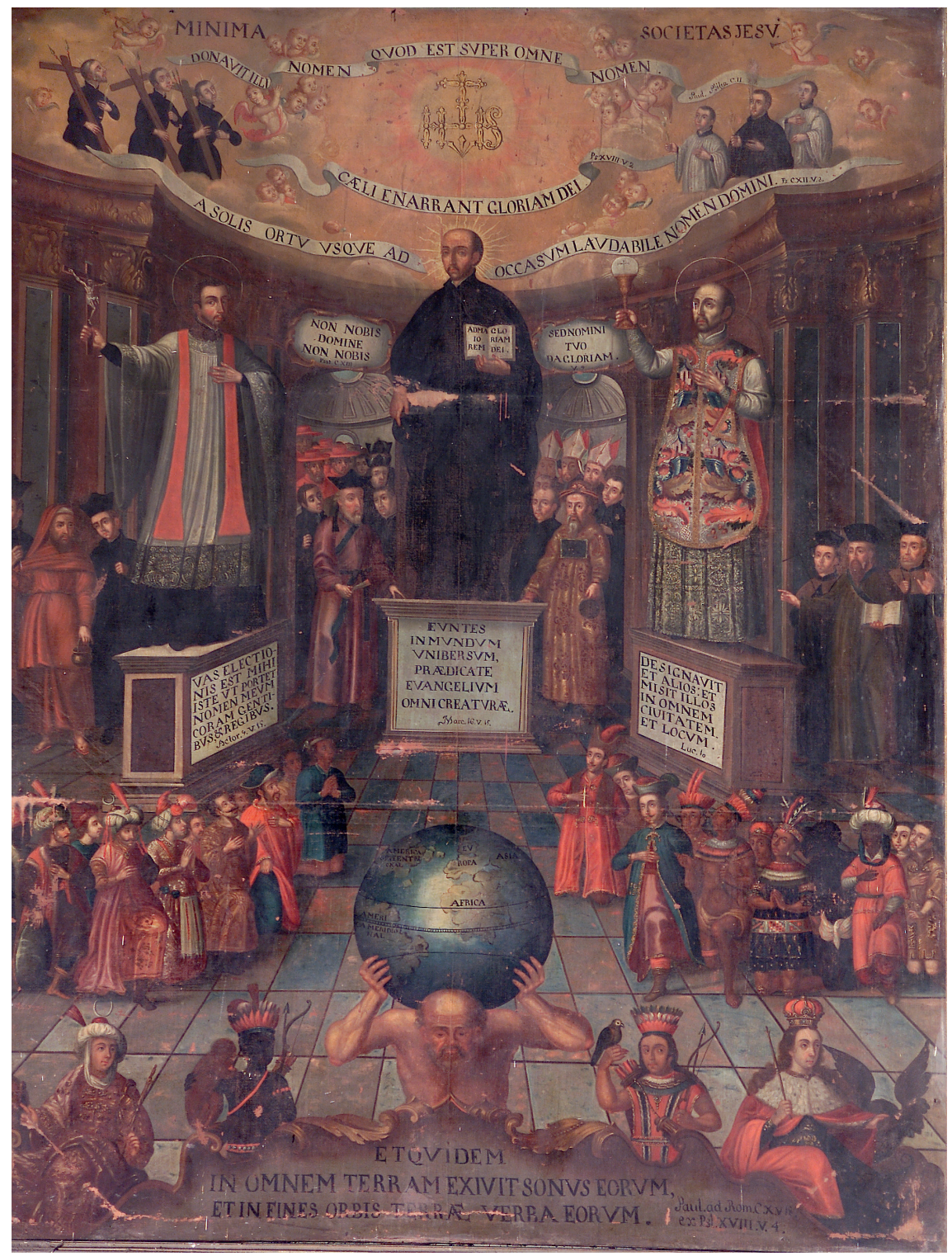

FIGURE 1 Alegoría de la Compañía de Jesús y su labor misional en los cuatro continentes (San Pedro, Lima, s. XVIII) 
island of Guåhan (today's Guam) ${ }^{9}$ on June 15, 1668 from the viceroyalty of New Spain along with five other Jesuits, the evangelization of the Marianas was officially launched, subsidized by Queen Mariana of Austria (1634-96), widow of Philip IV (r.1649-65) and regent for her son (1665-76) Charles II (16611700, r.1676-1700), who actively supported the Jesuits' missionary activities. ${ }^{10}$ Although the Jesuit missionaries wanted to reach Japan and other Pacific islands, such as the Palau and Caroline archipelagos, the crown encouraged them to stay in the Marianas until 1769 (when the Society of Jesus was expelled from the Philippines) to reinforce the Spanish presence on the fringes of the Pacific empire. In 1859, a group of Jesuit missionaries returned to the Philippines, but they never officially set foot on the Marianas during the nineteenth century.11 It was not until the twentieth century that they went back to Micronesia, taking charge of the mission on the Northern Marianas along with the Caroline and Marshall Islands, thus returning to one of the cradles of Jesuit martyrdom in Oceania.

\section{The Arrival of the Jesuits in the Philippines}

By the mid-sixteenth century, the Spanish crown had established an overseas empire of colossal dimensions. ${ }^{12}$ European trade from the Far East, established as early as the fifteenth century, formed circuits that played,

$9 \quad$ The native place names of the Mariana Islands have been prioritized, followed by the English translation in parentheses.

10 Not to mention Doña María Guadalupe de Lencastre, duchess of Aveiro, Arcos, and Maqueda (1630-1715), known as the "the Mother of the Missions," who financially supported the missionary project of Fr. Diego Luis de San Vitores (1627-72) from the start (Ward Barrett, "Preface," in Mission in the Marianas: An Account of Father Diego Luis de Sanvitores and His Companions [1669-1670] [Minneapolis: University of Minnesota Press, 1975], 1-62, here 8; Rafal Reichert, "La transcripción del manuscrito de fray Ignacio Muñoz sobre el proyecto de manutención y extensión de la fe católica en las Islas Marianas, y del descubrimiento y la conquista de las islas Salomón, siglo XVII," Estudios de historia novohispana 51 [2014]: 133-63, here 161). Doña María Guadalupe de Lencastre did the same when Father Francisco Eusebio Kino (1645-1711) traveled across the California peninsula, founding missions on his way north (Luke Clossey, Salvation and Globalisation in the Early Jesuit Mission [Cambridge: Cambridge University Press, 2008], 274).

11 María Aguilera Fernández, "La reimplantación de la Compañía de Jesús en Filipinas: De la restauración a la revolución filipina $\left(1815^{-1898}\right)$ ", (PhD diss., Universitat Autònoma de Barcelona, 2018).

12 Peer Schmidt, La monarquía universal española y América: La imagen del imperio español en la Guerra de los Treinta Años (1618-1648) (México, DF: Fondo de Cultura Económica, 2012), 451-66. 
however irregularly, into the growing Atlantic commercial system. ${ }^{13}$ As a matter of principle, Christianity was intolerant of religious diversity, precisely because Christian universalism asserted the historical and moral unity of humankind in religious terms. The Jesuits innovation lay in creating a new sort of "Christian empire" based on inclining, not forcing, human wills. ${ }^{14}$ As a result, the mission was "a frontier institution that sought to incorporate indigenous people into the Spanish colonial empire, its Catholic religion, and certain aspects of its Hispanic culture through the formal establishment or recognition of sedentary Indian communities entrusted to the tutelage of missionaries under the protection and control of the Spanish state." This "joint institution of indigenous communities and the Spanish church and state" was developed to put a stop to, or, at the very least, reduce the power of "enterprising civilians and soldiers" on the expanding frontier, which too often resulted in the abuse of the natives and "a heightening of antagonism."15

In the context of creating new imperial spaces, ${ }^{16}$ the Society of Jesus, the first religious organization with a global character, became the protagonist in the cultural and religious assimilation of the Iberian eastern realms, both Spanish and Portuguese. ${ }^{17}$ The Chinese empire's resistance to trading with the Spanish on the continent and the refusal of the Muslim sultans to abandon the Moluccas (Spice Islands) and Mindanao put a damper on the Habsburgs' plans for expansion in East Asia. ${ }^{18}$ These plans would not only have enhanced

13 Bernard Bailyn, "Introduction: Reflections on Some Major Themes," in Soundings in Atlantic History: Latent Structures and Intellectual Currents, 1500-1830, ed. Bernard Bailyn and Patricia L. Denault (Cambridge: Cambridge University Press, 2009), 1-8, here 4.

14 Girolamo Imbruglia, "A Peculiar Idea of Empire: Missions and Missionaries of the Society of Jesus in Early Modern History," in Jesuit Accounts of the Colonial Americas: Intercultural Transfers, Intellectual Disputes, and Textualities, ed. Marc André Bernier, Clorinda Donato, and Hans-Jürgen Lüsebrink (Toronto: University of Toronto Press, 2017), 21-49, here 24.

15 Robert E. Wright, O.M.I., "Spanish Missions," Handbook of Texas Online, Texas State Historical Association; http://www.tshaonline.org/handbook/online/articles/itso2 (accessed February 13, 2018).

16 My understanding of "empire" has much to do with "webs of trade, knowledge, migration, military power, and political intervention that allowed certain communities to assert their influence and sovereignty over other groups" (Tony Ballantyne and Antoinette Burton, "Introduction: Bodies, Empires, and World Histories," in Bodies in Contact: Rethinking Colonial Encounters in World History, ed. Tony Ballantyne and Antoinette Burton [Durham, NC: Duke University Press, 2005], 1-15, here 3); Charles H. Parker, Global Interactions in the Early Modern Age, 1400-1800 (New York: Cambridge University Press, 2010), 13-38.

17 Clossey, Salvation and Globalisation, 1-19.

18 Manel Ollé, "El Mediterráneo del mar de la Cina: Las dinámicas históricas de Asia oriental y la formación del modelo colonial filipino," in Imperios y naciones en el Pacífico, vol. 1, Colonialismo e identidad nacional en Filipinas y Micronesia, ed. María Dolores Elizalde Pérez-Grueso, Josep María Fradera, and Luis Alonso Álvarez (Madrid: CSIC, 2001), 59-72. 
the commercial dimension of the conquest but would also have facilitated the spread of Catholicism among the "infidels."

The few Jesuits who arrived in the Philippines in 1581-and eventually the Marianas - via New Spain in response to a plea addressed to the Spanish crown by governor and captain general of the Philippines Guido de Lavezaris (151282 , in office $1572-75$ ) fostered a global circulation of (missionary) knowledge. ${ }^{19}$ The religious and political authorities in the capital of the Spanish Philippines, Manila, decided to concentrate isolated barangays ${ }^{20}$ in villages, also known as doctrines or doctrinas, to facilitate evangelization and increase agricultural production and tribute collection. ${ }^{21}$

In the Americas, the Jesuit missions had been conceived as places in which the natives were to be reducti, that is, "transformed into Christian subjects who had learned to live according to the rules of political society." 22 In Peru, for instance, conquest by military means had proved insufficient to bring the remaining unconquered natives into submission. To fulfill this "spiritual conquest" of Andean territories, the Society of Jesus had already experimented with this practice of gathering the native population into villages - the so-called "reductions" in the towns of Cercado in 1571 and Juli in 1576 - even though in principle they contradicted the markedly itinerant, apostolic character-circa misiones - of their order. However, although the task of evangelizing corresponded primarily to the mendicant orders, by the end of the sixteenth century the tendency in the Americas was to replace friars with diocesan clergy. In the Philippines, such a transformation was not possible because there were not enough secular clergymen willing to undertake these ministries and because the Spanish population continued to be low, even in places that were already pacified. Therefore, regular clergy ended up serving as parish priests in strategic enclaves where the Spanish peninsular population ranged from scarce to none.

19 Charlotte de Castelnau-L'Estoile et al., eds., Missions d'évangélisation et circulation des savoirs, XVIé-XVIII $e^{e}$ siècle (Madrid: Casa de Velázquez, 2011); Wilde, Saberes de la conversión; Coello de la Rosa, Burrieza, and Moreno, Jesuitas e imperios de ultramar (siglos XVI-XX); Banchoff and Casanova, Jesuits and Globalization.

20 Barangays were the basic Tagalog political unit (Robert R. Reed, Colonial Manila: The Context of Hispanic Urbanism and Process of Morphogenesis [Berkeley: University of California Press, 1978], 11-16).

21 Regarding these reduction policies, see also René B. Javellana, "The Jesuits and the Indigenous Peoples of the Philippines," in The Jesuits: Cultures, Sciences, and the Arts, 1540-1773, ed. John W. O'Malley, S.J., et al. (Toronto: University of Toronto Press, 2000 [1999]), 1:418-38, here 428-30. 
However, the so-called Filipino frailocracia (the power of friars in the Philippines), as Marcelo Hilario del Pilar (1850-96) put it, did not limit the Jesuits' missionary impact. ${ }^{23}$ In fact, the acceptance of some reductions or parishes did not confine missionary activities to other more conflictive adjacent islands in the south (Mindanao, Sulu), which were under the influence of Islam, or to the archipelagos of the Marianas, Palau, and Carolines, which were located on the fringes of the Catholic Spanish empire. ${ }^{24}$ Upon his arrival in Manila in 1596, Fr. Superior Francisco de Vera (in office 1596-1605), whom governor of the Philippines Francisco Tello de Guzmán (1555-1603, in office 1596-1602) had chosen as his confessor, ${ }^{25}$ encouraged the peaceful evangelization of indigenous communities and aggressive activity against the so-called Moors (Muslims) who represented an obstacle to Christianity in the south. ${ }^{26}$ Mindanao and Sulu were two strategic points from which the Jesuits could access the Moluccas and the rest of the islands that today constitute Indonesia. ${ }^{27}$ As would happen years later with the Marianas, the Jesuits looked upon this island as their own, and with the collaboration of the civil authorities in the Philippines, they tried to convert the Sulu Muslims by any means. ${ }^{28}$

Schools or colegios were the Jesuits' starting point. From them, the members of the Society organized their so-called short-term flying missions, which were soon followed by the long missions that superiors sent to the groups of "infidels" across the Philippine territory. ${ }^{29}$ To attend to these multiple open

23 Marcelo H. del Pilar i Gatmaitan, La frailocracia filipina (Barcelona: Imprenta Ibérica de F. Fossas, 1889).

24 Alexandre Coello de la Rosa, Jesuits at the Margins: Missions and Missionaries in the Marianas (1668-1769) (London: Routledge, 2016).

25 Horacio de la Costa, S.J., The Jesuits in the Philippines, 1581-1768 (Cambridge, MA: Harvard University Press, 1989 [1961]), 154.

26 Pedro Chirino, Història de la província de Filipines de la Companyia de Jesús (1581-1606), ed. Jaume Górriz (Barcelona: Editorial Pòrtic, 2000 [1635]). Most Malay peoples in the lowlands or coasts were moros (Moors), while those in the interior were predominantly "Gentiles." These identity categories were constructed according to a religious, not ethnic, classification (Ana M ${ }^{a}$ Prieto Lucena, El contacto hispano-indígena en Filipinas [Córdoba: Servicio de Publicaciones de la Universidad de Córdoba, 1993], 235).

27 Francisco Colín-Pastells, Labor evangélica de los obreros de la Compañía de Jesús en las Islas Filipinas: Nueva edición ilustrada con copia de notas y documentos para la crítica de la historia general de la soberanía de España en Filipinas por el padre Pablo Pastells, S.J., 3 vols. (Barcelona: Imprenta y Litografía de Henrich y Cia., 1904 [1656]).

28 Francisco Combés, S.J., Historia de Mindanao y Joló (Madrid: Viuda de M. Minuesa de los Ríos, 1897 [1667]), book 2, $94 \mathrm{ff}$.

29 For an analysis of the different mission "types," see Aliocha Maldavsky, Vocaciones inciertas: Misión y misioneros en la provincia jesuita del Perú de los siglos XVI y XVII (Seville: Consejo Superior de Investigaciones Científicas, 2012), 71-124. 


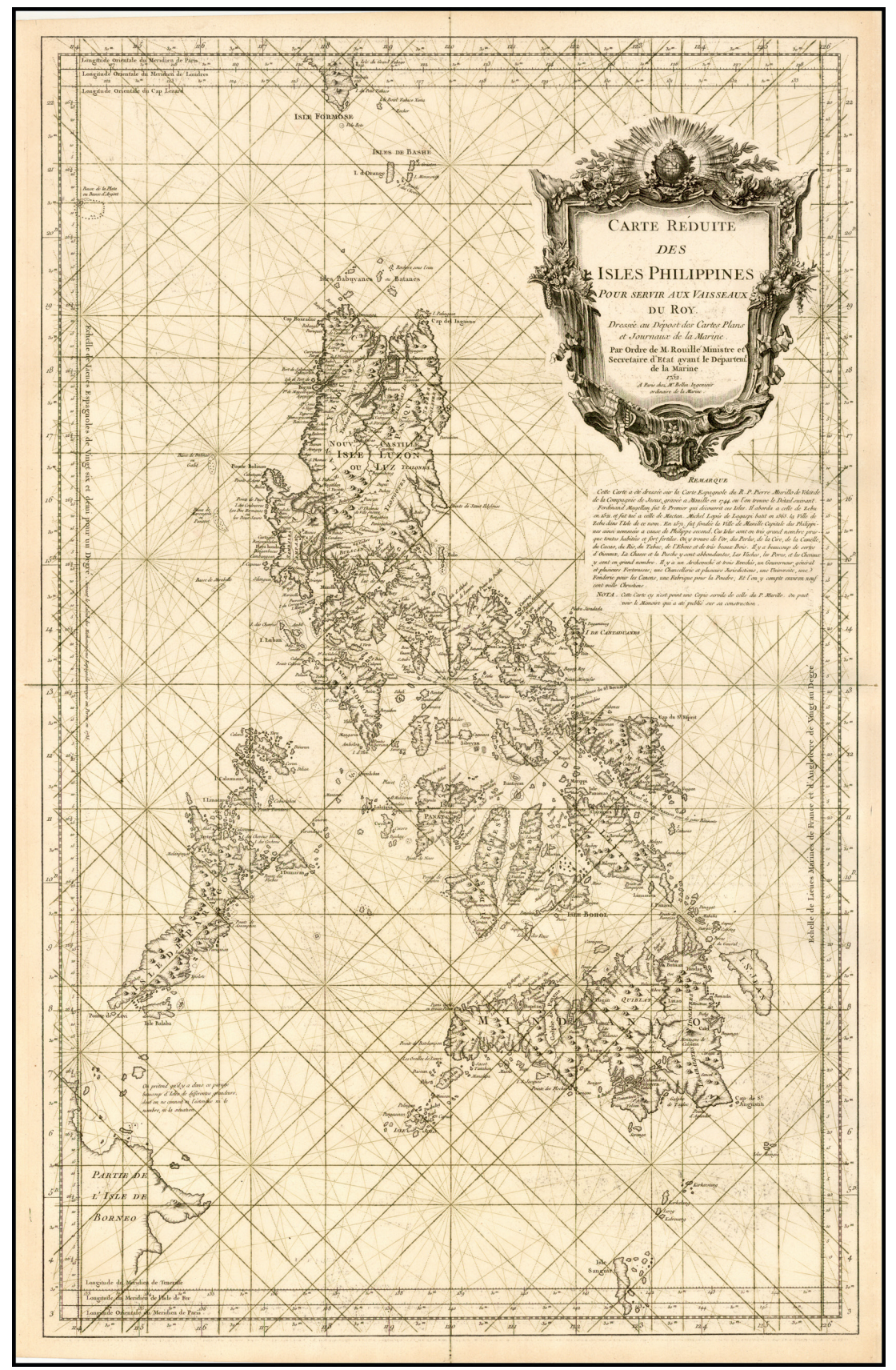

FIGURE 2 Map of the Philippines (1752), by Jacques-Nicolas Bellin (1703-72)

(Metropolitan Museum of Manila (exhibition catalog), "Three Hundred Years of Philippine Maps," 1598-1898, 38) 
fronts, Superior General Claudio Acquaviva (in office 1581-1615) sent twentyfive priests to the Philippines under the auspices of Philip II (r.1556-98), who promulgated a royal decree dividing the mission territory of this finis terrae into four areas of influence: Pampanga and Ilocos were to be ministered by the Augustinian order, Camarines and Tayabas by the Franciscans, the Visayan Islands by both the Augustinian and Jesuit orders, while the Dominicans were placed in charge of the evangelization of the Chinese population in the Manila Parian and the provinces of Pangasinan and Cagayan. ${ }^{30}$ As in the West Indies, the (re)organization of the natives was done around their submission to the parishes or curatos. However, the lion's share went to the Franciscan and Augustine friars, while the Jesuits received the poorest and least-populated areas of Samar and Leyte. ${ }^{31}$

\section{The Marianas as Part of the Universal Christian Project}

In the Philippines and elsewhere in the Spanish Empire, the care and control of the population was partly achieved through the subjection of the native populations to parishes. As historian Richard Kagan has observed, the Renaissance idea of a city contained two separate but complementary concepts: urbs, as a built environment, and civitas, as a human and political community. ${ }^{32}$ Since Iberian secular officials and religious priests equated "civilization" with urbanism, people who retained nomadic habits were, as Aristotle asserted, "barbaric, bestial, almost sub-human."33

In the sixteenth century, the Spanish word policía, derived from the Aristotelian term politeia, was used to refer to a community whose citizens were organized into an (ordered) civic polity or res publica. ${ }^{34}$ Following the in-

$30 \quad$ In 1605, not long after the first Chinese rebellion (1603), fourteen Augustine friars arrived in Manila, soon followed by the Brothers Hospitallers of San Juan de Dios, although the latter did not undertake missionary tasks (Ma Fernanda García de los Arcos, Estado y clero en las Filipinas del siglo XVIII [México, DF: Universidad Autónoma Metropolitana/ Iztapalapa, 1988], 50-51).

31 John Leddy Phelan, The Hispanization of the Philippines: Spanish Aims and Filipino Responses, 1565-1700 (Madison: University of Wisconsin Press, 1967 [1959]), 49-50; Lucio Gutiérrez, Historia de la iglesia en Filipinas (Madrid: Fundación Mapfre América, 1992), 71-73, 204; Gutiérrez, "The Formative Years of the Archdiocese of Manila (1565-1850)," Philippiniana sacra 46, no. 137 (2011): 453-80, here 471.

32 Richard L. Kagan, Urban Images of the Spanish World, 1493-1793 (New Haven: Yale University Press, 2000), 20.

33 Aristotle, Politics, trans. Ernest Baker (Oxford: Clarendon, 1946), 199 (book 3, chapter 9.12).

34 According to Sebastián de Covarrubias y Orozco: "Politeia, res publica, meaning polity, the urban, the polite and also politics, the science and mode of governing a city and a 
herited linkage between civitas and religio, the mendicant orders conveniently grouped the native population into organized towns or pueblos formados and turned New Spain into "New Jerusalem."35 In Michoacán, the parishes of San Francisco de Acámbaro (founded between 1526 and 1532) and Santa Fe de la Laguna, located on the riverbanks of Lake Pátzcuaro, together with the first village hospital in the Tarascan capital of Tzintzuntzan (founded in 1532), sought to protect the Indians from Spanish greed. ${ }^{36}$ The head of this short-lived project was Vasco de Quiroga (1480-1565), the future bishop of Michoacán (in office 1537-65), who was inspired by the critical humanism of Erasmus of Rotterdam (1466-1536) and, particularly, Sir Thomas More's (1478-1535) Utopia (1516), to concentrate the Indians in towns. ${ }^{37}$

In 1549, the Society of Jesus was sent to Brazil, where it built colleges, residences, and villages or aldeias for the social discipline of the Tupì population. In the coastal areas of Salvador de Bahia, in northeast Brazil, the Jesuits began developing the aldeamento system, the practice of settling and Christianizing indigenous peoples of diverse origins in supervised villages, under the rule of the first Portuguese governor-general Tomé de Sousa (1503-79, in office 1549-53). ${ }^{38}$ In Peru, the Jesuits helped build this town-based conception of the Christian empire. In the beginning, the Jesuits were reluctant to work as parish priests as a way of safeguarding their mobility and financial disinterestedness. ${ }^{39}$ However, this apostolic mobility had to be combined with a new pastoral strategy consisting of gathering the Christian flock everywhere in the Hispanic world into a hierarchically ordered world under a universal monarch (universitas cristiana). ${ }^{40}$

republic" (Sebastián de Covarrubias, Tesoro de la lengua castellana o española [Madrid: Turner, 1979 (1611), 875). See also Kagan, Urban Images of the Spanish World, 27-28; Imbruglia, "Peculiar Idea of Empire," 23.

35 Jerónimo de Mendieta, O.F.M., Historia eclesiástica indiana, ed. Joaquín García Icazbalceta (México, DF: Antigua Librería, 1870).

36 Charles Verlinden, "Las reducciones y los cambios estructurales en el México hispano (siglos XVI-XVII)," Revista complutense de historia de América 20 (1994):13-18, here 16-18.

37 Bishop Vasco de Quiroga was one of the first to denounce the existing contradictions in the "civilizing process." For more details about the ideas of Vasco de Quiroga and his reformist policy, see Fernando Gómez, "Experimentación social en los albores coloniales de la modernidad: El deseo utópico-reformista de Vasco de Quiroga (1470-1565)," Boletín americanista $5^{0}$ (2000): 101-21; James Krippner-Martínez, Power, Politics, and the History of the Early Colonial Michoacán, Mexico, 1521-1565 (University Park, PA: Pennsylvania State University Press, 2001), 77-83.

38 Charlotte de Castelnau-l'Estoile, Les ouvriers d'une vigne stérile: Les jésuites et la conversion des Indiens du Brésil, 1580-1620 (Paris: Centre Culturel Calouste Gulbenkian, 2000), 399-447.

39 Maldavsky, "Jesuits in Ibero-America," 95.

40 Maldavsky, Vocaciones inciertas, 8-13. 


\section{EL PLANO CUADRANGULAR APLICADO A LAS REDUCCIONES (MATIENZO)}
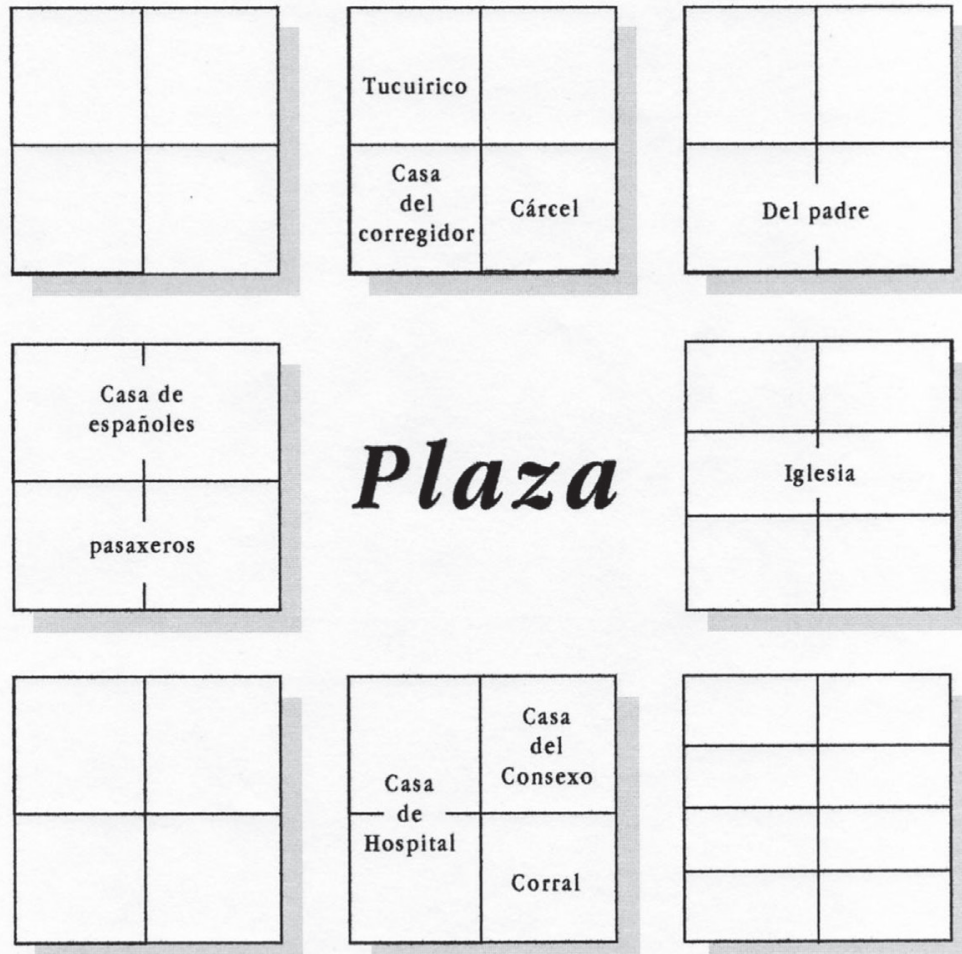

FIGURE 3 Juan de Matienzo's model of reduction (Gobierno del Perú, 1567)

The Jesuits were globalists, supporting and binding together an impressive number of missions, colleges, and residences from central Europe to the Philippines, India, China, and Japan, as well as to the Americas. ${ }^{41}$ The Jesuits, like other clergy, did not only act as ministers of God but also as political and

41 Bailyn "Introduction," 16-21. 
economic administrators of the missions in their care. In theory, their objectives were pervasively efficacious: Asian/Pacific peoples were evangelized for the greater glory of God (ad maiorem Dei gloriam), thus transforming them through missionary action. In practice, however, Jesuit identity was also deeply transformed by processes of indigenous resistance, borrowing, appropriation, and accommodation. ${ }^{42}$

Yet the natives of Micronesia were not regarded as belonging to sophisticated civilizations comparable to the Chinese and Japanese nations. They were inferior in moral terms, similar to the Indians inhabiting the Caribbean Islands. In return for avoiding eternal damnation, the destitute natives of the Marianas, unlike the Chinese and Japanese, were forced to renounce their beliefs and traditions and ultimately collaborate with the new political and religious authorities on the Pacific islands. To accomplish these goals, the Jesuits did not accommodate the natives in any way but rather applied peaceful methods that ended up being far more coercive and violent than expected.

To evaluate the limits of the cultural dialogue established between the Jesuit missionaries and local cultures, it is necessary to look at case studies that reveal the missionaries' objectives and the results they obtained. ${ }^{43}$ As noted earlier, the Jesuit mission in the Mariana Islands was founded in 1668 with the arrival of San Vitores, a Spanish missionary who strove to convert, or to "contract" in historian Vicente Rafael's words, "the foreign and dangerous into the familiar, the pleasurable, and the valuable." ${ }^{\prime 4}$ In February 1669, he built the first church in the town of Saint Ignatius Agaña (today's Hagåtña) on Guåhan. He dedicated it to the Sweet Name of Mary (Dulce nombre de María), thereby

42 "Accommodation" has been defined as a specific character of the Society of Jesus, namely a process of flexibility that allowed the Jesuits to accept all that could be accepted from various cultures (Michela Catto and Guido Mongini, "Missioni e globalizzazioni: Ladattamento come identità della Compagnia di Gesù," in Evangelizzazione e globalizzazione: Le missioni gesuitiche nell'età moderna tra storia e storiografia, ed. Michela Catto, Guido Mongini, and Silvia Mostaccio [Rome: Società editrice Dante Alighieri, 2010], 1-16). See also Joan Pau Rubiés, "The Concept of Cultural Dialogue and the Jesuit Method of Accommodation: Between Idolatry and Civilization," Archivum historicum Societatis Iesu 74, no. 147 (2005): 237-80, here 243 .

43 Rubiés, "Concept of Cultural Dialogue," 242.

44 Vicente L. Rafael, Contracting Colonialism: Translation and Christian Conversion in Tagalog Society under Early Spanish Rule (Ithaca: Cornell University Press, 1988), cited in Vicente M. Diaz, Repositioning the Missionary: Rewriting the Histories of Colonialism, Native Catholicism, and Indigeneity in Guam (Honolulu: University of Hawai'i Press, 2010), 18. 
repositioning Christianity, in historian Vicente Diaz's words, within local historical and cultural contexts. ${ }^{45}$

However, in translating pagan (read Chamorro) ideas into Catholic concepts, the Jesuits partially failed in reducing Chamorro cultural history to a simple converted object of colonialism. The missionizing of the Society of Jesus in the Marianas from 1668 to 1769 was like a continuum of cultural encountersa "contact zone" in the words of historian Marie Louise Pratt-where different power holders enjoyed great local autonomy, establishing asymmetrical relations of domination and subordination. ${ }^{46}$ From the very beginning, the conquest and colonization of these islands in Oceania was not a very profitable enterprise. Initially, they did not depend on the Philippines but on the viceroyalty of New Spain. Indeed, the lack of precious metals would have justified their abandonment, especially in comparison with the opulence of the American continent. Moreover, the topography of the Marianas was broken up by ravines and gullies, and its coasts were difficult to access for the galleons of the Acapulco route. ${ }^{47}$

But despite these inconveniences, the Jesuits wanted to remain there. They were clearly not guided by a desire for profit or adventure but by a manifest aspiration to their own salvation on some scattered islands of the Pacific and Terra Australis, which had scarcely been evangelized..$^{48}$ It was in the very act of preaching the Gospel to distant souls living on a cluster of islands in the vast Pacific that the Jesuit missionaries managed their concern for the least distant souls, their own. ${ }^{49}$ This powerful motive, highlighted by historian Pierre

45 On San Vitores's own mediating role in rediscovering so-called traditional Chamorro culture and identity as historically expressed in Spanish Catholic rituals over the last three centuries, see the seminal work by Diaz, Repositioning the Missionary, 23.

46 Unlike the Eurocentric perspective of colonial frontiers, the concept of contact zone is "an attempt to invoke the spatial and temporal co-presence of subjects previously separated by geographic and historical disjunctures, and whose trajectories now intersect" (Mary Louise Pratt, Imperial Eyes: Travel Writing and Transculturation [London: Routledge, 1997 (1992)], 6-7).

47 "Informe del padre Luis Pimentel, Provincial de las islas Filipinas de la Compañía de Jesús de las conveniencias e inconveniencias que puede tener la reducción a nuestra Santa Fe Católica de las islas que llaman de Ladrones" (Archivum Romanum Societatis Iesu [henceforth, ARSI ], Philipp. 14, Supplementum ad Historiam, 1584-1750, fols. $64^{\mathrm{r}}-68^{\mathrm{r}}$ ).

48 San Vitores was one of the advocates of the peaceful evangelization of the Marianas. For a notion of Jesuit spiritual conquest by non-violent means, see Imbruglia, "Peculiar Idea of Empire," 21.

49 Clossey, Salvation and Globalisation, 134. This can clearly be seen in the Fondo Gesuitico litterae indipetarum (indipetae) housed in the Archivio della Curia (ARSI) in Rome. Many Jesuits, especially Germans and Italians, asked the superior general to send them to the East Indies as missionaries, particularly to the Philippine and Mariana Islands. Apostolic 


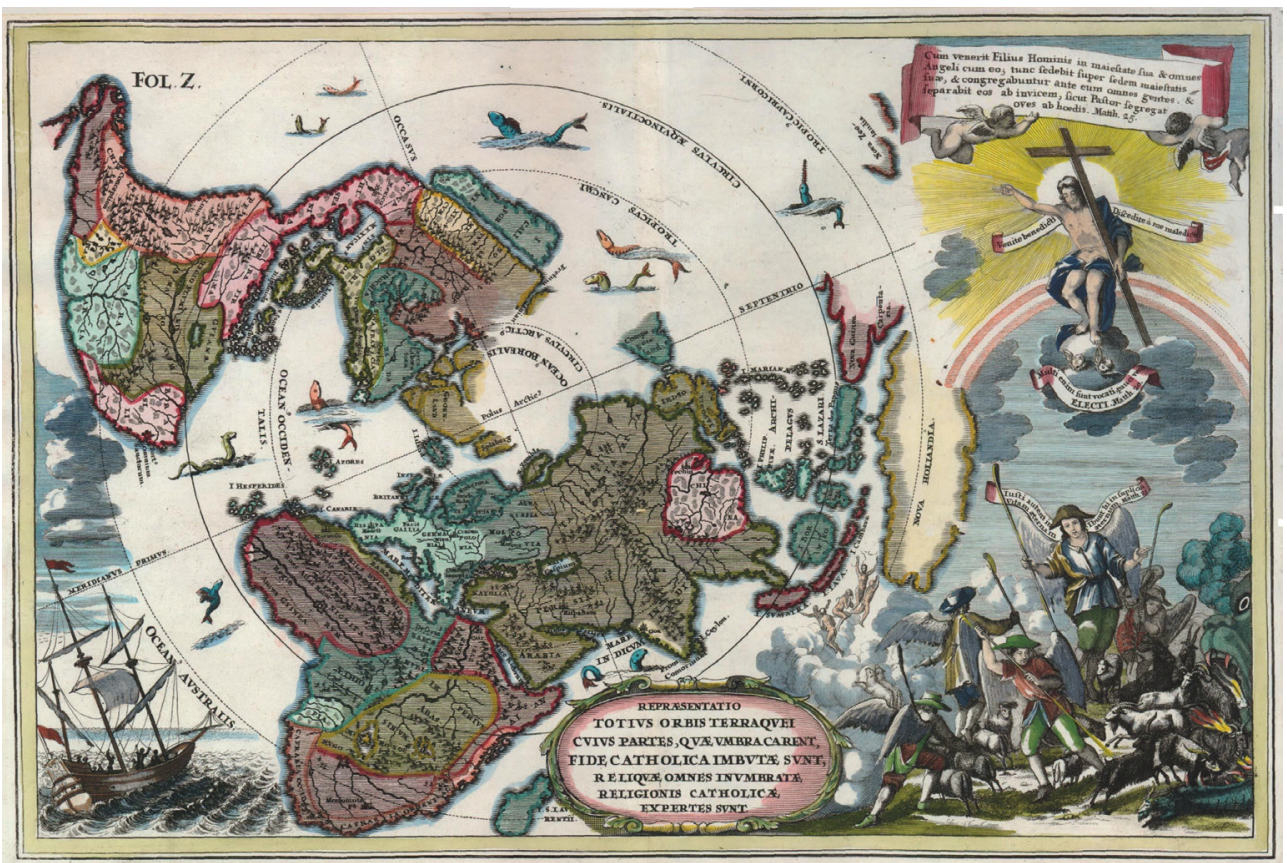

FIGURE 4 Heinrich Sherer's Repraesentatio totius orbis terraquei cuius partes, quae umbra carent, fide catholica imbutae sunt, reliquae omnes inumbratae religionis catholicae expertes sunt (c.1702)

Chaunu (1923-2009), challenges the opinion of scholars like Cynthia Ross Wiecko, who referred to the Jesuits as simple agents of the Spanish colonial empire.

This essay aligns itself with the scholarly work that confronts colonial assumptions of isolation, helplessness, and the dependency of the Marianas under Spanish sovereignty. ${ }^{50}$ If in the seventeenth century the islands represented a significant space for what historian Manfred Kossok (1930-93) has termed a "missionary frontier,"51 in the eighteenth the Bourbon monarchy

zeal and abnegation were upheld as the worthiest of virtues by these men of the cloth who hoped to become martyrs and attain sanctity. For a study of the indipetae sent from the Rhineland and upper Germany, see Christoph Nebgen, Missionarsberufungen nach Übersee in drei deutschen Provinzen der Gesellschaft Jesu im 17. und 18. Jahrhundert (Regensburg: Schnell \& Steiner, 2007).

$5^{0}$ For further information on how scholars of the Pacific have challenge these colonial assumptions, see Matt K. Matsuda, "The Pacific." AHr Forum, The American Historical Review 111, no. 3 (2006): 758-80.

51 Manfred Kossok, La colonització española d'Amèrica: Estudis comparatius (Barcelona: Avenç and Sociedad Catalana d'Estudis Històrics, 1991), 34. 
viewed the island of Guåhan as a possession of great strategic value- - a useful landfall" in the words of historian Robert Rogers - on the Manila-Acapulco galleon route, placing it within a global framework of colonial expansion. ${ }^{52}$ There is no doubt that the Philippines had been on the periphery of the Spanish Empire since the sixteenth century, but in relation to the southern islands of Mindanao, Sulu, Mindoro, and the Micronesian archipelagosthe Caroline and Marshall Islands, the Marianas and Palau — the Philippines constituted the political, economic, and intellectual center of Spanish Asia. ${ }^{53}$ Madrid was far away, and Manila, on the island of Luzon, became the most important Eurasian port because of Manila-based triangular relations between China, Japan, and New Spain. ${ }^{54}$

However, for spiritual purposes, Manila became the capital of the Spanish Asiatic empire for two fundamental reasons. The first was related to the internal frontiers established on Luzon itself, where the Spanish separated the subject Malays from the yet unconquered peoples; and the second, with the external frontiers in the south, where the Muslims of Mindanao and SuluMuslim Malays, Chamorros, Negritos, and so on-obstinately resisted the presence of the missionaries. ${ }^{55}$

The Society of Jesus extended its branches from Rome to every corner of the known world where the Jesuits had founded provinces and vice-provinces as basic units of the order's network. The provinces were brought together into five broad administrative divisions called assistancies, which corresponded to the major European states and their imperial possessions. ${ }^{56}$ Athanasius Kircher's (1602-80) Horoscopium catholicum Societatis Iesus, from his Ars magna lucis et umbrae (The great art of light and shadow), published in 1646 , provides an

52 Robert F. Rogers, Destiny's Landfall: A History of Guam (Honolulu: Hawai'i University Press, 1995), 1.

53 For a perspective that represents the Spanish Empire as less rigid and centralized, see Charlotte Castelnau-L'Estoile and François Regourd, eds., Connaissances et pouvoirs: Les espaces impériaux (XVI ${ }^{e}-X V I I I^{e}$ siècles); France, Espagne, Portugal (Pessac: Presses Universitaires de Bordeaux, 2005), 19.

54 Birgit Tremml-Werner, Spain, China, and Japan in Manila, 1571-1644: Local Comparisons and Global Connections (Amsterdam: Amsterdam University Press, 2015), 15-42.

55 Alexandre Coello de la Rosa, "Redes misionales y geo-estratégicas en Asia-Pacífico: El caso de Mindanao y Joló (siglos XVII-XVIII)," in Espacios misionales en diálogo con la globalidad: Iberoamérica, ed. Maria Laura Salinas and Lia Renata Quarleri (Resistencia, Argentina: Contexto, 2016), 23-47. See also García de los Arcos, Estado y clero en las Filipinas del siglo XVIII, $16-17$.

56 Clossey, Salvation and Globalisation, 23; José Gabriel Martínez-Serna, "Procurators and the Making of the Jesuits' Atlantic Network," in Bailyn and Denault, Soundings in Atlantic History, 181-209, here 185 . 


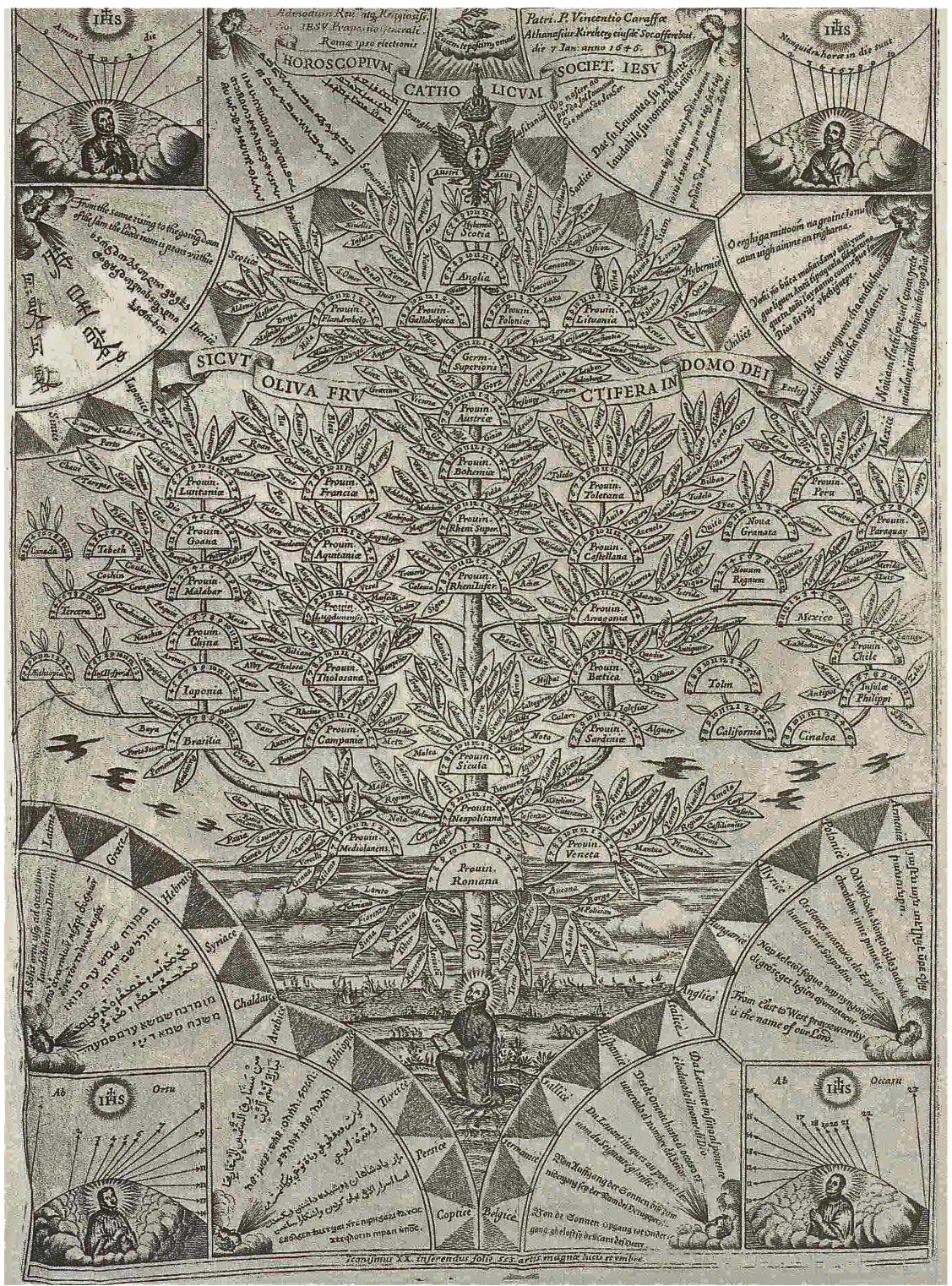

FIGURE 5 Athanasius Kircher's, Horoscopium catholicum Societatis Iesus, from his Ars magna lucis et umbrae (The great art of light and shadow) (Rome, 1646) 
outstanding metaphor for this tremendous expansion of the Society of Jesus, "as natural and expected as the growth of a tree."57

Early modern Manila, made the capital of the Jesuit province of the Philippines in 1605, branched out toward the Visayas, Mindanao, Sulu, and the neighboring Pacific islands under Spanish sovereignty. 58 The farthest extension of this missionary foliage were the Marianas, where the Jesuits arrived as part of a universal Christian project that stood proudly before the Protestant heresy that threatened the Iberian possessions in the Pacific.

Religious orders occupied privileged spaces in the Philippine power structure as spearheads of a Catholic order oriented toward the aggrandizement of the Habsburg monarchs in the oceanic enclaves of the Far East. In 1655, Jesuits Alejandro López (1604-55) and Juan de Montiel (1632-55) died at the hands of Sultan Muhammad Kudarat (r.1619-71) in southern Mindanao, victims of the violence of "frontier barbarians." ${ }^{59}$ Jesuit historians and hagiographers, such as Francisco Combés (1620-65) and Diego de Oña (1655-1721), had given a theatrical dimension to the spiritual conquest of the southern islands of Mindanao and Sulu. ${ }^{60}$ Later, Jesuit hagiographers such as Fathers Francisco García (164185) and Francisco de Florencia (1619-95) elevated the martyrs of the Marianas to the category of spiritual heroes who died in a cosmic struggle between good and evil, transforming their feats into strong elements of cohesion and identity for missionaries based in the archipelago. ${ }^{61}$ Certainly, hagiographic truth, based on a principle of canonical authority, had nothing to do with historical

57 Clossey, Salvation and Globalisation, 81; Martínez-Serna, "Procurators and the Making of the Jesuits' Atlantic Network," 182-89.

$5^{8}$ In 1605, Superior General Acquaviva constituted the Philippine province with a cosmopolitan group of eighty subjects - Spaniards, Italians, Austrians - that depended on the Spanish assisteny (De la Costa, Jesuits in the Philippines, 221; Javellana, "Jesuits and the Indigenous Peoples of the Philippines," 419).

59 They were not the only ones. On the northeastern coast of Mindanao, among many who lost their lives were Frs. Juan del Campo (1563-96), Juan del Carpio (c.1597-1648), Francesco Palliola (1612-48), and Juan del Campo (1620-50), not to be confused with the first missionary on Mindanao, who had the same name. See Combés, Historia de Mindanao y Joló, book 2, chapters 11-12, 133-43; book 7, chapters 13-14, 508-18.

6o I am currently working on the first Spanish edition of the second part of the Labor evangélica: Ministerios apostólicos de los obreros de la Compañía de Jesús (c.1701) by Diego de Oña. This book will be published in Madrid by Sílex (2019).

61 Combés, Historia, book 8, chapter 4, 550-70. 
truth, which is more concerned with factual veracity or historicity. ${ }^{62}$ The protagonists' lives were characterized as tragedies in which their various plights seemed predestined. ${ }^{63}$

The first reports written by Jesuit missionaries and procurators, such as Noticia de los progresos de nuestra santa fe (News of the progresses of our holy faith [1670]) by Andrés de Ledesma (1610-84), popularized the Jesuits' missionary efforts in the Marianas, helping to attract funds for frontier missions. ${ }^{64}$ As a matter of fact, other clerics with a missionary spirit had reached the Marianas before the Jesuits. In 1596, Antonio de los Ángeles (dates unknown), a member of the Discalced Franciscan order, jumped ship along with two soldiers while it was anchored, probably off Rota, and introduced Christianity to the Marianos (today's Chamorros) during his one-year stay. He returned to the Philippines in a Spanish galleon the following year. In October 16o2, Capuchin friars Juan Pobre de Zamora (d.1612) and Pedro de Talavera (dates unknown) sojourned on Rota for seven months, being repatriated to Manila in the Acapulco galleonJesús María. ${ }^{65}$ After this short-lived mission, which was limited to Rota, no other Spanish missionaries were sent to the Mariana Islands until the $1660{ }^{66}$

62 As historian Norma Duran observes, hagiographies provide more information on the social function of saints than historically accurate accounts of their lives (Retórica de la santidad: Renuncia, culpa y subjetividad en un caso novohispano [México, DF: Universidad Iberoamericana, 2008], 36).

63 Ibid., 38.

64 Barrett, "Preface," 6-8.

65 Fray Juan Pobre de Zamora (called so to distinguish him from Fray Juan Pobre of Sanlúcar de Barrameda, also a missionary in the Far East) was one of Duke Alba's veterans in Flanders, and later on, he became a Franciscan lay brother, sailing for the Philippines in 1594. As historian Charles R. Boxer observes: "He inspected the Franciscan mission stations in Japan in $1595^{-1596}$, and after returning to Manila, embarked for Mexico in the great galleon San Felipe, which was wrecked off Tosa in October. He narrowly escaped being involved in the martyrdom of February 1597, and was deported in the Portuguese carrack Santo Antonio to Macao, whence he made his way to Manila in January 1598. He was sent to Spain next year, and returned with a band of missionaries in 1602, but 'jumped ship' at Guam en route, where he remained for seven months (not a year, as is usually stated) before being picked up by the Manila-bound galleon Jesús María (October 1602). He returned to Spain in $1603^{-4}$, and spent the next three years between Valladolid and Rome, battling for the revocation of Gregory XIII's pro-Jesuit Brief of 1585 , which was eventually achieved, largely through his efforts, in 1608 . He returned to the Philippines in the last year, and thence for the third time back to Europe in 1611, but by the way of Portuguese India, the Persian Gulf, and Mesopotamia. The peripatetic friar died at Madrid five years later, on the eve of his intended fourth departure for the Philippines" (Charles Ralph Boxer, The Christian Century in Japan, 1549-1650 [Berkeley: University of California Press, 1967], 481).

66 Frank Quimby, "Islands in the Stream of Empire: Spain's 'Reformed' Imperial Policy and First Proposals to Colonize the Mariana Islands, $1565^{-1569, " ~ p a p e r ~ p r e s e n t e d ~ a t ~ t h e ~ F i r s t ~}$ Marianas History Conference, "One Archipelago, Many Stories" (2012). 


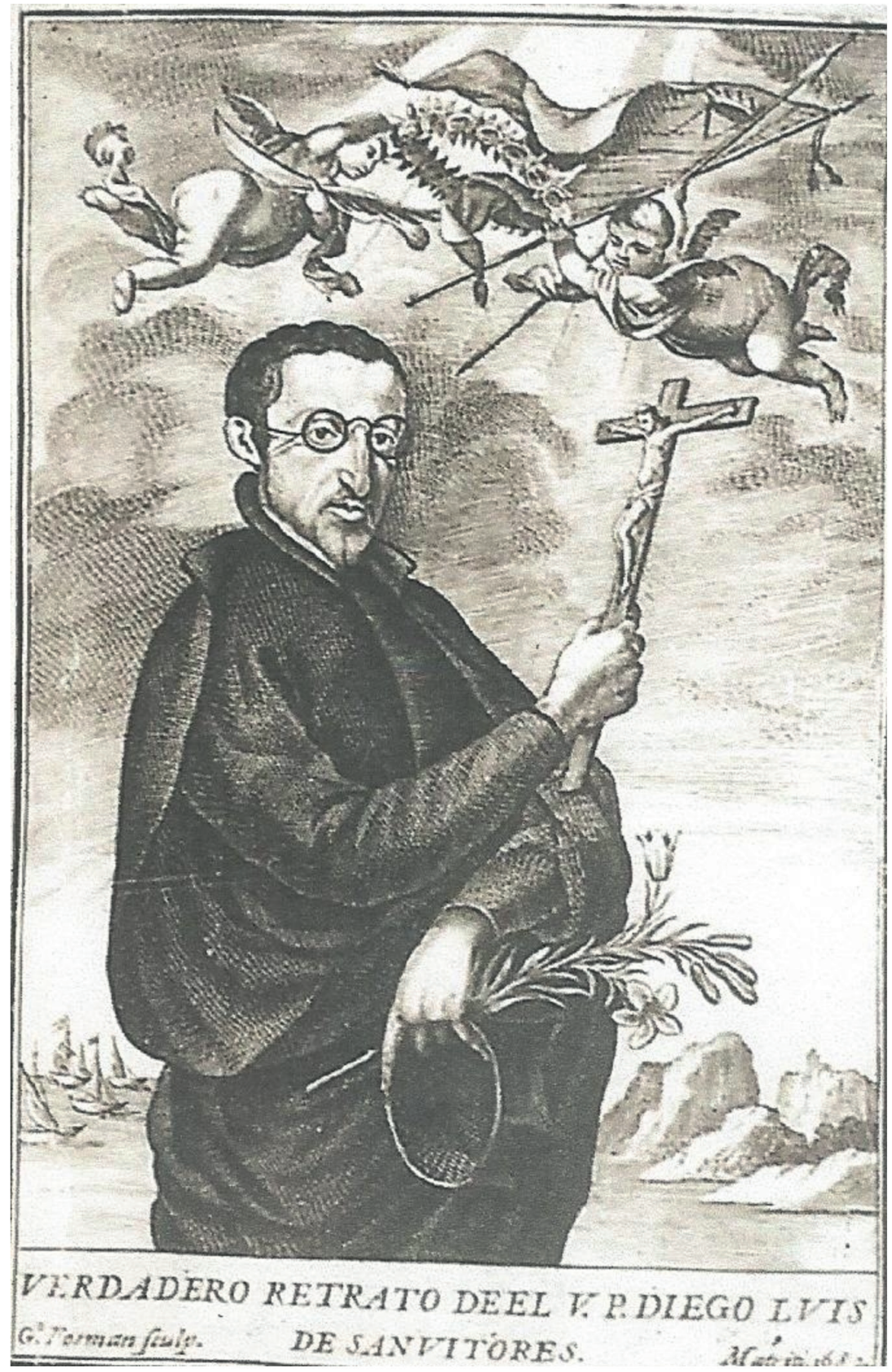

FIGURE 6 Martyrdom of Diego Luis de San Vitores (Francisco García, Vida y martyrio del padre Diego Luis de Sanvitores, de la Compañia de Jesus, primer apostol de las islas Marianas y sucessos de estas islas (Madrid: Juan García Infanzón, 1683) 


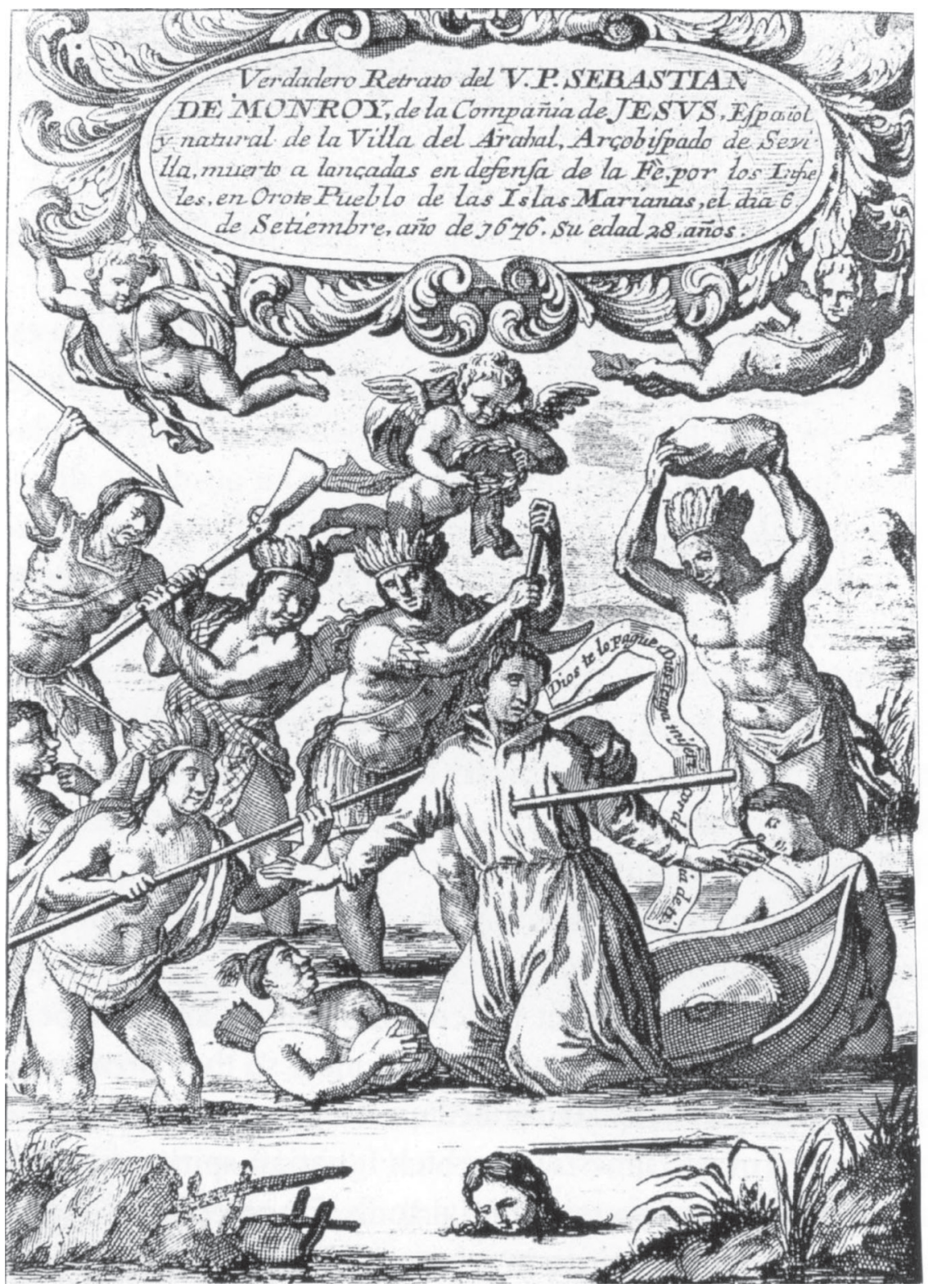

FIGURE 7 Martyrdom of Father Sebastián de Monroy (Gabriel de Aranda, Vida y gloriosa muerte del Venerable Padre Sebastián de Monroy de la Compañía de Jesús, que murió en las islas Marianas (Sevilla, Imprenta de Tomás López de Haro, 169o) 
During the initial evangelization phase of the Mariana Islands between 1668 and 1676, Jesuits San Vitores, Luis de Medina (1637-70), and Sebastián de Monroy (1649-76), among others, became illustrious heroes of the Catholic mission, dying at the hands of Matå'pang, Hirao, Aguarin (or Agua'lin), and other "indomitable barbarians" in their defense of the faith. As the culmination of this missionary experience, martyrdom transformed the islands not only into a frontier and seedbed of martyrs but also into central reference points, places where missionaries had spilled their blood.

In 1679, the Royal Audience of Manila ordered the deployment of a punitive expedition to secure the pacification of the Chamorro villages through conversion and/or reduction. Along with the German, Italian, and Spanish Jesuits who had arrived in the galleon San Antonio de Padua, the new mission's superior, Bartolomé Besco (1614-80), agreed that force was necessary to subjugate the resistance of the dissident groups led by Aguarin and other chiefs. The Jesuits - ten priests, three coadjutor brothers, and oblate Felipe Sonsón (1611-86) $)^{67}$ - worked to reduce and evangelize the subdued population (repartimiento), while the civil authorities promoted the distribution of the surviving captives among soldiers and particulars. As Ross Wiecko has noted: "Reducción was at the heart of the increased militarization of Guåhan, with both the government and the military charged with supporting this ecclesiastic policy." 68

However, these Jesuit missionaries, under the direction of San Vitores, cannot be considered simple agents of the Spanish Empire. They were imbued with a messianic and metaphysical language that justified martyrdom as a means to a higher end. There were other "heroes" as well, laymen who joined the martyrs as moral touchstones of conquest and colonization, particularly the pious Galician José de Quiroga y Losada, captain and sergeant major of the Hagåtña presidio and interim governor from 1680 to 1681 . He was a tough commander whose severity and force succeeded in destroying the Chamorro opposition, punishing the seditious Mariana natives - termed "barbaric, fierce, and Jesuit-killers" - who in 1676 had taken the life of, among others, Antonio María de San Basilio (1643-76). Instead of gaining the enmity of the Jesuits for

67 Oblates were individuals, either laypersons or clergy, who had individually affiliated with a religious or monastic order by means of a formal, private promise to follow the rule of the order.

68 Cynthia Ross Wiecko, "Jesuit Missionaries as Agents of Empire: The Spanish-Chamorro War and Ecological Effects of Conversion on Guam, 1668-1769," World History Connected 10, no. 3 (2013), http://worldhistoryconnected.press.illinois.edu/10.3/forum_wiecko.html (accessed February 13, 2018). 
his cruel methods, however, Quiroga won their gratitude and trust. ${ }^{69} \mathrm{He}$ set about capturing and executing those who had been directly responsible for the deaths of Spaniards and Jesuits, including Hurao and Aguarin, the latter being captured in Rota and executed in 1680 on Guåhan. ${ }^{70}$

Chamorro soldiers, interpreters, and collaborators, such as Ignacio de Hineti (or Hinesi), the "good Christian" from Sinajana, and the lieutenant governor and captain general of Guåhan, Antonio de Ayihi (d.1701), who tenaciously defended the Spanish missionaries against the Chamorro insurgency of 1684, were also "heroes" of the Marianas. ${ }^{71}$ As some scholars have noted, European colonial empires could not have been built without the effective collaboration of local indigenous groups, and the conquest of the Marianas was no exception. Like Hernán Cortés (1485-1547), Francisco Pizarro (1478-1541), and other conquistadors of the Americas, the Spanish invaders of the Marianas integrated native soldiers and auxiliaries as valuable allies in their military forces. ${ }^{72}$

Quiroga's government lasted for only a year. On June 13, 1681, the new governor, Antonio de Saravia y Villar (in office 1681-83), arrived in Guåhan from Mexico as governor and captain general of the Marianas, dependent on the Royal Audience of Manila. ${ }^{73}$ Saravia was an experienced soldier who had

69 See the letter written by Fr. Tomás Vallejo to Provincial Tirso González, Hagåtña, June 14, 1680 (Bibliotheca Americana et Philippina, part 3, catalog no. 442, Maggs Bross, 1923, 131). In another letter (to the duchess of Aveiro, Taytay, June 20, 1680), Jesuit provincial Francisco Salgado (1629-89) praised "the good hermit Don Joseph de Losada [...] a man of great virtue, good health, and good intentions, with which I hope he will greatly aid the missionary fathers in the conversion of those barbaric infidels" (Charles Ralph Boxer, "Two Jesuit Letters on the Mariana Mission, Written to the Duchess of Aveiro [1676 and 1689]," Philippine Studies 26 [1978]: 35-50, here 44). See also Marjorie G. Driver, Cross, Sword and Silver: The Nascent Spanish Colony in the Mariana Islands (Guam: Micronesian Area Research Center [MARC] and University of Guam, 1987), 33; Rodrigue Lévesque, History of Micronesia: A Collection of Source Documents (Quebec: Lévesque Publications, 1992), 7:263-67.

70 Annual letter of 1680-81 (Lévesque, History of Micronesia, 7:462). See also Pedro Murillo Velarde, Historia de la provincia de Filipinas de la Compañía de Jesús: Segunda parte que comprende los progresos de esta provincia desde el año de 1616 hasta el de 1716 (Manila: Imprenta de Nicolás de la Cruz Bagay, 1749), fol. $34^{\mathrm{v}}$.

71 Since colonial discourses were meant to confer legitimacy on the institutional order that colonizers sought to impose, any policies, acts, or ideas that questioned, altered, or resisted that juridical normativity were considered anomalies that required correction. See Max Hering Torres, "Introducción," in Cuerpos anómalos, ed. Max Hering Torres (Bogotá: Universidad Nacional de Colombia, 2008), 13-28, here 16-17.

72 Wayne E. Lee, Empires and Indigenes: Intercultural Alliance, Imperial Expansion, and Warfare in the Early Modern World (New York: New York University Press, 2011).

73 Governor Saravia arrived in Guåhan aboard the galleon San Antonio with his servants Juan Moreno and Antonio Sotera with a royal decree that confirmed his post; royal decree 
served in Sicily for thirty years and who was apparently close to the Society of Jesus. ${ }^{74}$ With the collaboration of the faithful Chamorros, Saravia promoted the evangelization and conquest of the Northern Mariana Islands (Gani Islands), including those where the first missionaries had already done some evangelizing work before the initial wave of violent Chamorro resistance in the mid-1670s. He also sought to reinforce the peace and reorganize the population according to stable residence patterns. The pagan villages that had not been militarily conquered were to pay a tribute in labor and goods that recognized their vassalage to the Spanish king, while those that had accepted Christianity were distributed in several villages or reducciones, despite their resistance, and for the next forty years they were exempted from paying tribute. ${ }^{75}$

Following the model imposed in the Philippines, new patterns of semiurban settlement (reducciones) were applied, gathering the various houses and ranches around the presidio into three barrios, which concentrated some three hundred families. ${ }^{76}$ Soon after, the natives were forced to live in five districts or partidos (Hagåtña, Humåtac, Hågat, Inalåhan, and Pågu), governed by alcaldes mayores, each comprising small towns or municipios, mostly across the coastal zone. These alcaldes were more like military overseers or foremen who supervised the agricultural and livestock production of each partido. ${ }^{77} \mathrm{At}$ the head of the town dwellers was a native gobernadorcillo (little governor) or a fiscal (akin to a governor at a cabildo), and several barrios whose inhabitants

of November 13, 1680 ("Expediente de información y licencia de pasajero a Indias de Antonio Saravia, gobernador y capitán general de las islas Marianas," Archivo General de las Indias [henceforth, AGI ], contratación, 5443, N. 1, R. 5, fols. 1-10 v). Sergeant Major Quiroga left the Marianas and settled in Manila, where he filled the post of superintendent of the Royal Hospital (AGI, Filipinas 13, fol. 97, cited in Driver, Cross, Sword, and Silver, 20; and Marjorie G. Driver, "Notes and Documents: Quiroga's Letter to King Philip V, 26 May 1720," Journal of Pacific History 27, no. 1 [1992]: 98-106, here 99).

74 Luis de Morales remarked that Governor Saravia publicly displayed his esteem for the missionaries of the Guåhan parishes ("Relaciones del estado y progresos de la misión de las islas Marianas desde junio de 1681 hasta el 25 de abril de 1684." Real Academia de la Historia [henceforth, RAH], Fondo Jesuitas, vol. 19, signature: 9-3593/26, fol. $1^{\mathrm{r}}-2^{\mathrm{r}}$ ).

75 For the first forty years after the colony was officially established, Indian adults who converted to Christianity were exempt from tribute. After this period, tribute was expected from those who were married and between the ages of twenty and fifty (Arxiu Històric de la Companyia de Jesús a Catalunya [henceforth, AHCJC], "Relación y documentos referentes a las islas Marianas, 1668-1673," FILPAS, 52, fol. 349 ). See also AHCJC, "Relación de la misión de las Marianas desde el año de 1682 hasta el 24 de abril presente de 1684," FILPAS, 52 , fol. $360^{\mathrm{r}}$ ).

76 Annual letter of 1679-8o (RAH, 9/2677, transcribed in Lévesque, History of Micronesia, 7:218-21); Fr. Bartolomé Besco's letter to Procurator Pedro de Espinar, Hagåtña, June 10, 1684 (Lévesque, History of Micronesia, 7:255-57).

Driver, "Notes and Documents," 101. 
were under the direction of pre-Hispanic chiefs or datos were grouped together. Each town had a patron saint and a church or chapel, and the Jesuits organized cofradias (confraternities) and schools for the evangelization of the natives. ${ }^{78}$ In the Marianas mission, the Jesuits had almost exclusive control over the dynamics of conquest and colonization, but the fierce resistance presented by the natives meant that war was practically inherent in Spanish and Jesuit frontier policies.

Spanish colonization, of which Christianization was a fundamental aspect, was experienced by the native Chamorros as an exercise in exploitation, forcefulness, and humiliation. In an eloquent letter written in 1683 to Doña María Guadalupe de Lencastre y Cárdenas Manrique, the duchess of Aveiro (1630-1715), a patron of the Society of Jesus known as the "Mother of the Missions," Baltasar de Mansilla (1638-92), procurator of the Philippines and the Marianas, ${ }^{79}$ wrote:

The office of governor in the Marianas is nothing but a step towards the same post in the Philippines, and it can even be considered a novitiate for the latter for, not having any stimulus to acquire riches in the Marianas, they go to the Philippines with modest pretensions, not spurred by ambition. ${ }^{80}$

These words foreshadowed the tense relations between Jesuit missionaries and the governors of the Marianas. The physical violence of the conquest also contributed to the construction of the Christian God as far from the loving being the Jesuits strove to present. The system that emerged was a militarized society that depended on the extortion of baptized natives. Like the regular clergy in the Philippines, the Jesuit missionaries taught children different trades at the rebuilt school of San Juan de Letrán so that they could work as carpenters, shoemakers, and the like instead of pursuing a less technical education. ${ }^{81}$ In fact, in a 1681 letter to García, Lorenzo Bustillo (1642-1716) accused the superior Manuel de Solórzano (1649-84) of neglecting the true educational duties of

78 Patricio Hidalgo Nuchera, La recta administración: Primeros tiempos de la colonización hispana en Filipinas (Madrid: Polifemo, 2001), 53-54.

79 Carlos Sommervogel, S.J., Bibliothèque de la Compagnie de Jésus: Nouvelle édition (Brussels: Oscar Schepens, 1894), 5:506.

8o Fr. Baltasar de Mansilla's letter to the duchess of Aveiro, Mexico, August 13, 1683, transcribed in Lévesque, History of Micronesia, 8:31. Author's translation.

81 According to Murillo Velarde, by 1679 there was already a new building with adequate living quarters for the number of seminarians and a chapel dedicated to Our Lady of Guadalupe (Murillo Velarde, Historia de la provincia de Filipinas, 295). 
the Society and treating and preparing the youngsters as if they were slaves. ${ }^{82}$ He also complained about the polos, an institution of free labor that obligated the natives to work unpaid for the crown for a given number of days every year-usually forty - in a system not unlike the Peruvian mita forced mining labor system, with similarly devastating results and negative reactions. ${ }^{83}$ Having adapted the Filipino system of barangay chiefdom, some priests used their influence over the chiefs to obtain free native labor to build and repair houses and other buildings, raise and tend to the animals, and work their private and church lands. ${ }^{84}$

After the Second Great War (1683-86), the Jesuits organized Guåhan into a republic by reducing it to five assigned districts or parishes-St. Ignatius of Hagåtña, St. Rose of Hågat, Humåtac, Pågu, ${ }^{85}$ and Inalåhan (or St. Anthony of Fina) - that separated civilization from barbarism, "the world of the polis from the world of the beasts." ${ }^{86}$ Using presidio funds to transform the island of Guåhan into a model Spanish mission, military officers founded congre-

82 Fr. Lorenzo Bustillo's letter to Fr. Francisco García, Hagåtña, May 27, 1681 (Bibliotheca Americana et Philippina, part 3, catalog no. 442, Maggs Bross, 1923, 141-42).

83 Polo work, one of the most onerous personal services expected from the natives, was spent constructing and/or repairing public works of all sorts (churches, roads, ships, bridges, etc.). See Luis Alonso Álvarez, "Repartimientos y economía en las Islas Filipinas bajo dominio español, 1565-1815," in El repartimiento forzoso de mercancías en México, Perú y Filipinas, ed. Margarita Menegus (México, DF: Instituto de Investigaciones Dr. José María Luis Mora and Centro de Estudios sobre la Universidad [UNAM], 2000), 170-216, here 179-80; Luis Ángel Sánchez-Gómez, "Las elites nativas y la construcción colonial de Filipinas (1565-1789)," in Las relaciones entre España y Filipinas: Siglos XVI-XX, ed. Ma Dolores Elizalde Pérez-Grueso (Madrid: CSIC, 2004), 37-70, here 50.

84 For an analysis of the pre-Hispanic kinship system of the barangay in the Philippines, see Nicholas Cushner, Spain in the Philippines: From Conquest to Revolution (Quezon City, Philippines: Institute of Philippine Culture, 1971), 5. For an analysis of the use of native labor for private enrichment, see Omaira Brunal-Perry, "La legislación de Ultramar y la administración de las Marianas: Transiciones y legados," in Elizalde, Fradera, and Alonso, Colonialismo e identidad nacional en Filipinas y Micronesia, 395-406, here 403; BrunalPerry, "Las islas Marianas enclave estratégico en el comercio entre México y Filipinas," in España y el Pacífico: Legazpi, ed. Leoncio Cabrero (Madrid: Sociedad Estatal de Conmemoraciones Culturales, 2004), 1:543-56, here 554.

85 Lévesque, History of Micronesia, 8:12. The church in Pågu was built in 1689, after the statue of the Purísima Virgen, lost during the 1684 uprising, was finally found. For the community of believers, images or statues of virgins or saints constitute a symbol of their collective identity, along the lines of a coat of arms or a flag. It is not surprising, then, that this find encouraged the re-consecration of the partido and the construction of a new mission house (ARSI, Lorenzo Bustillo "Relación del estado y progresos de la misión de las islas Marianas desde mayo pasado de 1689 hasta el de 1690," Supplementum ad Historiam, 1584-1750, 14:fols. $75^{\mathrm{r}}-75^{\mathrm{v}}$ ).

86 Kagan, Urban Images of the Spanish World, 27. 
gations, parishes, and schools to advance the Christianization of the islanders. ${ }^{87}$ As a result, the municipality of St. Ignatius of Hagåtña attained a certain size and importance as Thomas Aquinas's (1224/25-74) notion of the city as a perfecta communitas (or perfect community) to successfully evangelize the islands of Gani. In recognition of its loyalty, on March 30, 1686, Charles II issued a royal decree granting St. Ignatius of Hagåtña the status of city. At the same time, he declared Humåtac a villa, a higher status. ${ }^{88}$ Unfamiliar with these developments, the Chamorros continued trickling north to Gani, which prompted the governor to organize a new expedition of twelve Spanish soldiers and a large number of faithful natives commanded by Captain Sebastián Luis Ramón (dates unknown) to bring them back to Guåhan. ${ }^{89}$

On July 26, 1696, General José de Madrazo, the new interim governor of the Marianas (in office 1696-99), expressed his determination to relocate and reduce Gani's natives to the main islands-Guåhan, Saipan, Rota-to be instructed and educated in the Christian faith. At that time, the Jesuits clearly had the political and religious leadership of the islands in their hands, becoming the founders of a missionary state in which martyrs were permanent moral reference points for years to come. However, the situation was far from being as idyllic as represented by Jesuit historian Antonio Astrain (1857-1928). ${ }^{90}$ In the long run, the resettling of the Chamorros into reducciones failed in the eyes of the Jesuits as the only way to divert the natives from nomadism and establish good sociability. There was no systematic policy of extermination, but the illness and epidemics of 1700 , natural disasters such as the typhoons of 1671 and 1693, hard labor, continuous wars, and migration all took their toll on the population. In 1701, the natives of the Marianas and Mindanao wrote a letter to King Philip v (r.1700-15; r.1724-46) describing the miserable situation created by the Spanish governors and asking him to address their long-standing

87 "Relación del estado y progresos de la misión y cristiandad" (AHCJC, FILPAS, 64, fols. $48^{\mathrm{r}}-65^{\mathrm{r}}$ ); "Carta anua de la misión de Marianas: Año 1699" (ARSI, Philip. 14, fols. 92-93v, transcribed in Lévesque, History of the Marianas, 10:73-177). See also Francis X. Hezel, S.J., From Conquest to Colonization: Spain in the Mariana Islands, 1690 to 1740 (Saipan: Mariana Islands Division of Historic Preservation, 1989), 24.

88 See the Memorial (1685) written by Luis de Morales (Lévesque, History of Micronesia, 8:413); Marjorie G. Driver, The Spanish Governors of the Mariana Islands: Notes on Their Activities and the Saga of the Palacio; Their Residence and the Seat of Colonial Government in Agaña, Guam (Guam: Richard F. Taitano \& Micronesian Area Research Center, 2005), 10.

89 "La reducción de las islas de Gani, 1697-1698" (ARSI, Philip. 14, fols. 88-91v, transcribed in Lévesque, History of Micronesia, 10:182-90).

90 Antonio Astrain, Historia de la Compañía de Jesús en la asistencia de España (Madrid: Administración de Razón y Fe, 1925), 6:831-35. 
grievances. ${ }^{91}$ And, indeed, the Chamorro demographic collapse was cause for a great deal of concern in the Spanish court.

Near the end of the seventeenth century, Jesuit universal Christianity aspired to win the Marianas over to Catholicism, transforming "that untilled jungle of weeds" into a "beautiful and pleasant garden." ${ }^{\text {92 }}$ However, in truth, at the beginning of the eighteenth century, there were few souls left to conquer. Letters from missionaries and accounts of the time constantly spoke of the continued decline of the Chamorro population caused by warfare, infectious diseases, and hunger. ${ }^{93}$

Over time, the Philippine governors began to consider the Marianas a cumbersome and expensive burden. Since the arrival of the first Jesuit missionaries in Guåhan in 1668, their perceived isolation in relation to Manila, poverty, and lack of mineral resources meant that the islands had to be subsidized by the empire. The Acapulco galleons needed to stop regularly in the archipelago with the royal situado, the subsidy funds from the vice-regal treasury of Mexico. Some merchants and many among the Manila authorities argued that this practice had a detrimental impact on the regular traffic of the Acapulco trade route and went so far as to recommend that the galleons go on their way and leave the Mariana Chamorros to their own devices. This was the view of Governor Diego de Salcedo (d.1669, in office 1663-68), who, according to Fr. Luis de Morales (1641-1716), "had secretly ordered the captains of the ships that went from New Spain to the Philippines not to touch the island of Guåhan, so that the missionaries in them, left without assistance and at the mercy of the barbarians, die or are forced to abandon the islands." 94

At the turn of the eighteenth century, the political climate on the Marianas was fraught with rigidity and intransigence. The repression exercised against the natives had decreased their numbers alarmingly, while the political and

91 "Memorial de los indios de las islas Marianas y de Mindanao (Filipinas) al rey [Felipe v], para que ponga remedio a los agravios que sufren por parte de su gobernador" (Sección Nobleza del Archivo Histórico Nacional [henceforth, AHN], Osuna, C. 387, D. 31, fol. 1 v).

92 ARSI, Filipinas 13, fols. 111-18, transcribed in Lévesque, History of Micronesia, 6:205-6.

93 Glynn Barratt, The Chamorros of the Mariana Islands: Early European Records, 1521-1721 (Saipan: Division of Historic Preservation and the Micronesian Area Research Center, 2003), xi.

94 Luis de Morales and Charles Le Gobien, History of the Mariana Islands, ed. Alexandre Coello de la Rosa (Mangilao, Guam: University of Guam Press, 2016), 183-84. 
religious control of the islands was being consolidated in Spanish hands. Appointed officials and alcaldes mayores placed greater labor demands on the surviving natives as their numbers dwindled, which in turn led to even higher levels of violence and exploitation.

The demographic situation of the Marianas would remain a central issue for later governors. Decimated by internecine warfare and epidemics, the Chamorro population of the Mariana Islands barely reached 3,500 souls by the early 1700s. Between May 1699 and April 1700, 263 children had been baptized, but 378 baptized adults and 139 children had died of disease, which disrupted the Chamorros' intergenerational cultural continuity. The policy of relocating the natives on the eight islands of Gani into reducciones must be understood as a way of palliating this demographic collapse and making the mission worthwhile. ${ }^{95}$

In 1701, Procurator General Andrés Serrano (1655-1711) left the Philippines to travel to Rome and Madrid, where he informed his superiors about the state of the province and requested more missionaries for the Philippines as well as for the "distended regions of the new Philippines, or the austral islands of Palos" that had been recently discovered. ${ }^{96}$ The 1702 annual letter reported that there were twelve Jesuits in the Marianas: ten priests; a coadjutor brother, Neapolitan Jacobo (or Jaime) Chavarri (1663-1741), who served as physician, surgeon, and apothecary; and an oblate brother, Melchor de Santa Cruz (dates unknown), who worked in the children's school in Pågu from 1700 to $1703 .{ }^{97}$ Furthermore, according to the reports submitted, the zeal and observance of the natives had increased in comparison with previous years, when skirmishes occurred practically every day in the midst of constant wars. ${ }^{98}$ The continued violence exercised against the native population, as well as the scourge of epidemic diseases, had forced the Chamorros to accept Christianity as the only possibility of survival. Since their arrival in 1668 , the Jesuits had become the horticulturists — to use the words of historian Jorge Cañizares-Esguerra ${ }^{99}$ —of

95 A total of 834 adult newcomers from the Gani Islands were baptized. ARsi, "Misión de Marianas de la Compañía de Jesús año de 170o," Litterae annuae Philippinae, vol. 8 (16401749), fol. $73^{\mathrm{r}}$.

96 "Memorial del padre Andrés Serrano al Felipe v (1706)" (Archivo Histórico del Colegio Jesuita de la Provincia de Toledo [henceforth, AHCJPT], Filipinas C-285, doc. 2 , fols. $1^{r}-1^{v}$ ).

97 "Puntos para la Carta Anual de la misión de las Marianas de la Compañía de Jesús: Año de 1702" (ARSI, Philipp. Suppl. 1584-1750, 14:fol. 94 ${ }^{\mathrm{r}}$ ).

98 "Misión de Marianas de la Compañía de Jesús año de 1700" (ARSI, Litterae annuae Philippinae, vol. 8 [1640-1749], fols. $71^{\mathrm{v}-73^{\mathrm{r}}}$ ).

99 On the idea of colonization as "spiritual horticulture," see Jorge Cañizares-Esguerra, Puritan Conquistadors: Iberianizing the Atlantic, 1550-1700 (Stanford: Stanford University Press, 2006), 178-214. 
those "new plants that needed continual care so as not to be strangled by the weeds of their old ways."100 However, the real danger faced by these "plants" was not the precariousness of their rooting, but the cruelty and greed of their caretakers, the representatives of the Spanish crown.

In effect, governors and alcaldes mayores placed greater labor demands on the surviving natives as their numbers dwindled, which led to even higher levels of exploitation and violence. ${ }^{101}$ This encouraged various escape attempts, such as one by a pair of Chamorros who in the early 1700 s ran away from the reducción with their (unwed) partners to the interior of the island of Rota,

and since this bad example could be the cause for many others to do the same, with great harm to the entire mission, all the efforts that seemed possible were done to bring them out, and since human efforts did not seem to be enough, I [Fr. Johann Tilpe $\left.\left(1644^{-1710}\right)\right]^{102}$ went to the Apostle Francis Xavier offering him ten Masses said consecutively in the same number of Fridays, asking him to free the island of this scandal and take pity on these miserable souls, reducing them to a better life, for in another time they had been parishioners in the residence in Agussan, the partido [district] to which all four of them belonged. I was finishing the saying of these Masses, and on the tenth Friday, having finished the last Mass, the guiltiest one made himself seen, he had come at the wrong time to ask for a job [fol. 73] in the house of an acquaintance whom he had for a confidant, but this man instead of giving him tobacco, barred him inside, and helped by others who later went, he tied his hands and handed him over [...]; the wench who had come with him seeing that the deal had not gone well slipped away and came to retire in the island, and the rest did the same soon after, on the day of the Virgin's assumption the other one came with his concubine, and so with the help of the Virgin and Saint Francis Xavier we sighed from so much work and apprehension from other worse consequences that these brigands brought upon us. ${ }^{103}$

100 "Misión de Marianas de la Compañía de Jesús año de 170o" (ARSI, Litterae annuae Philippinae, vol. 8 [1640-1749], fol. $72^{\mathrm{r}}$ ).

101 On April 23, 1706, Vice-Provincial Gerardo Bouwens (1633-1712) wrote a letter denouncing the exploitation that the Chamorros were subjected to (Hezel, From Conquest to Colonization, 42-49).

102 In 1688, Father Tilpe was ministering in the parishes of Humåtac Bay and Agat in the island of Guåhan. In 1693, he was sent again to Humåtac, and from 1695 to 1708 he was in charge of the parishes in the island of Rota. Finally, in 1709 he was appointed viceprovincial of the Marianas.

103 Fr. Johann Tilpe's letter, "Resident in the Island of Rota of the Marianas to Fr. Joaquin Asin Who Resides in the Philippines," Rota, October 26, 1700 (ARSI, Litterae annuae 
For the Jesuits, however, one of the main arguments for the continued Spanish sovereignty over the Marianas was the monarchy's commitment to evangelization. For example, Bustillo, acting commissary of the Holy Office, argued that if they were abandoned, the souls of the Chamorros would be irredeemably condemned. ${ }^{104}$ According to Governor Francisco de Medrano y Asiaín, sergeant major, general captain, and acting interim governor of the Marianas (in office 1700-4), the native population of the Marianas had diminished drastically, and as a result he recommended that the islands be progressively relinquished given their limited lucrativeness. On the contrary, Bustillo thought that the population decrease was not as large as it seemed, and even if it were, this was no reason to dismantle the military outpost; on the islands of Puerto Rico, Cuba, and Santo Domingo, there were barely any natives left, and the crown had not abandoned them. For this reason, Bustillo continued, the governor of the Philippines, Domingo de Zubálburu (in office 1700-9), knight of Santiago, was much more generous than his predecessor, promising that "as long as he governed the Philippines he would order that all the ships come by here and anchor without exception." 105

The irregularity of the arrival of the situado subsidy in the Marianas was another concern for the Jesuits, as reflected in letters written by the missionaries who had been in the Marianas. ${ }^{106}$ The first such letter, written by provincial (in office 1699-1703) and former missionary Morales, to procurator Antonio Jaramillo (1648-1707) on June 9, 1700, accused the outgoing Philippine governor Fausto Cruzat y Góngora (d.1702, in office 1690-1701) of not sending a $p a-$ tache scheduled to reach the Marianas in 1698, sending it instead in July 1699, and during the storm season, at great loss to the royal treasury. ${ }^{107}$ The second, written by Bustillo to Superior General Tirso González de Santalla (in office 1687-1705) on April 14, 1702, warned of the Philippine governor's machinations against the Society of Jesus, blaming him for the dire needs experienced by

Philippinae, vol. 8 [1640-1749], fols. $73^{\mathrm{r}}{ }^{-73^{\mathrm{v}}}$. My translation. See also Hezel, From Conquest to Colonization, 28).

104 Lorenzo Bustillo, "Reparos sobre el arbitrio y lo imposible de su ejecución," dated April 10, 1702 (ARSI, Litterae annuae Philippinae, 1663-1734 [etiam de Insulis Marianis], fol. $328^{\mathrm{v}}$ ).

105 Fr. Lorenzo Bustillo’s letter to Fr. Tirso González, Hagåtña, April 14, 1702; "Reparos sobre el arbitrio," fols. $327^{\mathrm{r}}-33^{\mathrm{r}}$.

106 The royal situado that arrived in the Marianas from 1710 to 1715 was valued at 29,914 pesos, seven tomines, and three granos (AGH, AH H 1733, fols. 1, 4 , 6-6 $6^{\mathrm{v}}$, transcribed in Lévesque, History of Micronesia, 11:155).

107 RAH, Fondo Cortes, 9/2669/46, fol. $1^{\text {r }}$; transcribed in Lévesque, History of Micronesia, 10:238-39. These delays were a common occurrence. The 1696 patache brought with it the 1695 situado along with the corresponding 1696 one, including a total of ten thousand pesos for the two schools of boys and girls, as well as 8,725 pesos for synod expenses. The 1698 situado was indeed sent in 1699 (Lévesque, History of Micronesia, 10:72-73, 164-65). 
the missionaries during the last few years. ${ }^{108}$ Arguing that there were pirates off their coasts, the governor ordered the galleons not to stop in the Marianas, but to continue on to Manila. ${ }^{109}$ Bustillo also wrote a detailed, twenty-sevenpoint list in which he questioned the vehement, illusory notions of Governor Medrano, especially regarding the transfer of the Marianas' inhabitants, which he found entirely impracticable. ${ }^{110} \mathrm{He}$ asked the provincial of the Philippines as well as the general procurator of the missions in the Philippines, Francisco de Borja y Aragón (1582-1658) -who, "being related to the monarchy could [get a lot done] in Madrid" - to intercede for the souls of the mission. ${ }^{111}$

All these issues profoundly disappointed Morales, who in June 1700 addressed a letter to Procurator Jaramillo from Manila in which he praised interim governor Medrano, although these sentiments were untrue. ${ }^{112}$ In 1701, Medrano wrote a parecer, or report, to the king recommending the transfer of the 2,6oo surviving Chamorros to the Philippine islands. Medrano argued that the small number did not justify the maintenance of the presidio and the Jesuit schools and houses. He added that, since the number of natives on the Gani Islands had been successfully reduced in the last four years, there should be no major problems in attempting the relocation. ${ }^{113}$

108 In this regard, see "Ordenanzas de Gobierno de don Fausto Cruzat y Góngora," in "Papeles sobre las misiones en Filipinas: Siglos XVII-XVIII," Biblioteca Nacional, MS 11.014.

109 Whenever this happened, which was quite frequently, the Marianas were compensated with two thousand pesos, which came in the next situado ("Reparos sobre el arbitrio," fol. $33^{2}$ ). For an interesting analysis of the expansive piracy networks in the Americas, see Kris Lane, Pillaging the Empire: Piracy in the Americas, 1500-1750 (New York: Routledge, 1998).

110 Bustillo's arguments clearly appealed to common sense. As one of the first Jesuit novices to reach the islands, he knew perfectly well what he was talking about. He had participated in most of the Chamorro wars and knew the resistance and difficulty implied in their submission. Moreover, he accused the governor of not explaining the means that would be required to transfer more than three thousand people. The islands had no forts, castles, or prisons to keep the natives in custody while the transfer took place. Bustillo discarded using native boats because on the 1696 voyage from Gani to Guåhan, Rota, and Saipan, many of these had shipwrecked. That left only one possibility: using the pataches and galleons from Acapulco. However, the lack of space in them meant that, at most, only two hundred natives could be transported a year, rendering this transfer entirely unfeasible ("Reparos sobre el arbitrio," fols. $329^{\mathrm{r}}-33^{\mathrm{r}}$ ).

111 In 1703, the order's general procurator Borja y Aragón levied a tax of 5,300 pesos on the Jesuit hacienda of Texcuco in New Spain to be sent to the Marianas mission to try to alleviate the needs of their fellow priests ("Relación de censos: Año 1774," Archivo Histórico Nacional, Sección Clero/Jesuitas, Bundle 891/5, fol. $24^{\mathrm{r}}$ ).

112 RAH, Fondo Cortes, 9/2669/46, fol. $\mathrm{r}^{\mathrm{r}}$.

113 ARSI, Litterae annuae Philippinae, vol. 13, 1663-1734 (etiam de Insulis Marianis), fols. $326-33^{\mathrm{v}}$. See also Hezel, From Conquest to Colonization, 54. 
However, most governors, such as Damián de la Esplana (1641-94, in office 1674-94) and Juan Antonio de Pimentel (in office 1709-20), exercised extreme violence over the territory and its population, imposing a regime of forced labor. More often than not, missionaries were forced to collaborate with the civil authorities in the colonies, even if those authorities were hard to control. Not only was the Chamorro population that the Jesuits sought to convert practically exterminated by the near-enslavement they endured to enrich the colonial officials but the Christian faith preached by the missionaries and supposedly shared by the authorities was devalued as a result.

On the other hand, some missionaries, like Ignacio de Ibarguen (1681-1730) and Giovanni Antonio Cantova (1686-1731), were persecuted and even exiled for daring to denounce the excesses committed by corrupt governors such as Pimentel and Luis Antonio Sánchez de Tagle (in office 1720-25). This domestic violence, much less heroic than that described in the hagiographies, provoked frustration and discouragement, a sour disappointment with the world that made the provincials wonder whether it was worth maintaining that Pacific vice-province. This does not mean, of course, that the Jesuits were not equally responsible for the collapse of Chamorro society. The more virtuous and sophisticated gentile peoples were able to accommodate the new faith to their old precepts, like the Chinese with Confucianism, thus finding the salvation of the church. ${ }^{114}$ But the formerly friendly Chamorros of the Marianas were forced to convert to Catholicism, renounce their pagan rites and customs, and collaborate with the new religious and civil authorities. Nor did the missionaries repudiate the use of violent means to reach this end. However, in pursuing this aim, they were not leading a "Spanish genocide," a claim some school textbooks in Guåhan have widely popularized. ${ }^{115}$

The refinement and sophistication of Chinese and Japanese cultures described by Jesuits Valignano and Ricci, and to a lesser extent by José de Acosta (1540-1600), were harshly contrasted with the perceived ignorance of Chamorro culture. ${ }^{116}$ Unlike those great Eastern civilizations, the inhabitants of

114 As Rubiés notes: "The identification of the moral philosophy of Confucius with ancient Stoicism was indeed his key theological gamble, as Ricci could build upon the acceptance of Stoicism as an acceptable prelude to faith within Christian humanism" ("Concept of Cultural Dialogue," 257). See also Joan-Pau Rubiés, "The Concept of Gentile Civilization in Missionary Discourse and Its European Reception," in de Castelnau-L'Estoile et al., Missions d'évangélisation, 289-328, here 322-28.

115 David Atienza de Frutos, "Priests, Mayors and Indigenous Offices: Indigenous Agency and Adaptive Resistance in the Mariana Islands (1681-1758)," Pacific Asia Inquiry 5, no. 1 (2014): $31-48$.

116 Alessandro Valignano, Sumario de las cosas de Japón (1583) y Adiciones del Sumario de Japón (1592), ed. José Luis Álvarez-Taladriz, Monumenta Nipponica Monographs 9 (Tokyo: 
Micronesia were never regarded as potentially equal to those of the European nations. Upon translating Christian dogma to local cultural expressions, the Jesuits never tried to attract them culturally because they considered them too politically and morally inferior. To understand the particularities of Jesuit accommodation in the so-called East Indies, the Marianas must be situated in the wider context of imperial geographies, that is to say, in the colonial spaces where missionaries, as agents of social change, played a fundamental role in the construction of a social and political order in the Pacific.

At the beginning of the eighteenth century, the Spanish authorities sought to extend and maintain their control over peripheral areas using a policy of conciliation and evangelization instead of military domination. This largely corresponded to a lack of resources, something that also inhibited the colonization of these areas in terms of re-population. But the Society did more than simply defend the interests of a Catholic absolute monarchy and its allies; it defended a corporative model of religious organization for the overseas territories. ${ }^{117}$ Its members were not "organic intellectuals" but actors in a cosmic drama dominated by a fundamental contempt for the world. The idea of Spain as a tragic and chosen people characterized those baroque spirits who were willing to perform the greatest sacrifices in order to rescue new souls and extend Christ's faith. The mission of the Marianas followed the same plan of missionary expansion designed by the Society and the Holy See in the framework of the Protestant Reformation. The church's highest authorities considered it urgent to reinforce the presence and activity of the Catholic Church in Asia to stop the advance of the "heretic" enemies (Protestants, Calvinists). The missionary ideal of San Vitores sought to imitate the missions that Xavier had carried out in Asia (and continued by Italian Jesuits Valignano and Ricci). ${ }^{118}$ The castle in Navarre where Xavier was born became a place of pilgrimage

Sophia University, 1954); Matteo Ricci, Dieci capitoli di un uomo strano, ed. Filippo Mignini and Wang Suna (Macerata: Quodlibet, 2010); José de Acosta, Historia natural y moral de las Indias, critical edition by Fermín del Pino Díaz (Madrid: csic, 2008). On the evangelizing strategies of the Italian Jesuits Valignano, Michele Ruggieri (1543-1607), and Ricci in China, see Nicolas Standaert, S.J., "Jesuit Corporate Culture as Shaped by the Chinese," in O'Malley et al., Jesuits: Cultures, Sciences, and the Arts, 1:352-63.

117 Steven J. Harris, "Mapping Jesuit Science: The Role of Travel in the Geography of Knowledge," in O'Malley et al., Jesuits: Cultures, Sciences, and the Arts, 1:212-40, here 228-33.

118 Léon Bourdon, La Compagnie de Jésus et le Japon, 1547-1570 (Lisbon: Centre Culturel Portugais de la Fondation Calouste Gulbenkian, 1993), particularly chapters 5 and 6, 153-94; Andrew C. Ross, "Alessandro Valignano: The Jesuits and Culture in the East," in O'Malley et al., Jesuits: Cultures, Sciences, and the Arts, 1:336-51. 
visited by missionaries before embarking toward faraway lands. The expansion of the Catholic Spanish monarchy as the harbinger of the true faith justified the wars fought in the territories of Asia and the Americas in God's name. And the Christian religion constituted an important element of ideological and functional identity that could not be overlooked.

The incorporation of the Marianas into the Christian imperium was, as was wont, a violent one. The desire of Medina and San Vitores to die as martyrs in the Marianas was the greatest expression of their wish to identify and honor Jesus Christ's crucifixion. Certainly, the hope of dying for Christ was not exclusive to the Jesuits and extended to missionaries of all orders, but the symbolic death of San Vitores in the line of duty seemed to have had the effect of multiplying the martyrdom of the Jesuits in the islands. ${ }^{119}$ All those deaths represented a resonant victory over the native population, whose islands were consecrated as a Christian space. If the price paid by the Jesuits seemed high, the price paid by the Mariana natives was even higher. When the Spanish arrived, their estimated population was some thirty thousand in around 180 settlements across Guåhan. ${ }^{120} \mathrm{~A}$ few years later, there were only around 3,678 individuals, according to a 1710 Spanish census. ${ }^{121}$ Faced with this demographic collapse, the crown and the Council of the Indies exempted the natives from paying tribute, but the islands' governors continued the practice of forcefully exacting products, service, and labor from Chamorro men, women, and children (going so far as to include presidio soldiers).

119 The first published reports, such as Jesuit Andrés de Ledesma's Noticia de los progresos de nuestra santa fe (1670), as well as the hagiographies of Frs. Francisco de Florencia (161995) (Seville, 1673), José Vidal Figueroa (dates unknown) (México, 1675), Francisco García (1641-85) (Madrid, 1683), and Gabriel de Aranda (1633-1709) (Seville, 169o), praised the missionaries who died at the hands of the non-subjugated Indians, especially San Vitores, Medina, and Fr. Sebastian de Monroy (1649-76), while forgetting the auxiliaries, servants, and lay catechists who helped them in the evangelization process. Historians John N. Schumacher, S.J., and Resil B. Mojares have rescued some of these men-Felipe Sonsón, Pedro Calungsod (1654-72) — who died along with the Jesuits, analyzing their life histories as well as the processes of beatification and sanctification promoted on their behalf.

120 Don A. Farrell, History of the Mariana Islands to Partition (Saipan: Public School System of the Northern Mariana Islands, 2011), 195.

121 Astrain, Historia de la Compañía de Jesús, 7:762; Laura Thompson, "The Native Culture of the Marianas Islands," Bernice P. Bishop Museum Bulletin 185 (Honolulu: Kraus Reprint Co., 1971 [1945]), 3-48, here 3; Don A. Farrell, History of the Northern Mariana Islands (Saipan: Public School System of the Northern Mariana Islands, 1991), 176; Charles Henry Cunningham, The Audiencia in the Spanish Colonies as Illustrated by the Audiencia de Manila (1583-1800) (Berkeley: University of California Press, 1919), 53. 
In the Iberian Far East, spatial boundaries constituted peripheral societies in which the degrees of corruption and crime were basically proportional to the distance from the governing center. However, even though the Mariana Islands were not isolated, self-contained units, but rather interrupted by a more or less constant exchange of persons, merchandise, and information, the Marianas' governors had great leeway and autonomy vis-à-vis the authorities in Manila and New Spain. They and their favored subalterns were de facto lords who did as they pleased with their private fiefdoms.

The low salaries received by royal officials were complemented by a traditional mindset that justified using a government post for personal benefit. ${ }^{122}$ This encouraged, and was also encouraged by, the patrimonial character of corporate power groups and local elites, with their extensive family connections, which were perennially involved in disputes over the control of political power. In his Monarquía hispánica (1600-4), Tommaso Campanella (15681639) had already warned the king about the dangers of privatizing the post of governor. Venality of office was not recommendable because it encouraged the chosen individuals to profit through illegal means. According to this Calabrian Dominican friar, "there are high officials who sell small posts to those they later steal from; and so, in small territories the common right is not observed, for while officials pretend to propagate the king's jurisdiction, they encourage hatred by ruining the poor subjects."123

The local administration in the Marianas continually succumbed to this venality of office. The defining characteristics of the Marianas' governorstheir habitus, as Pierre Bourdieu (1930-2002) would say-especially of de la Esplana, Pimentel, and Sánchez de Tagle, was the indiscriminate exploitation of the Chamorro population through a network of majordomos, alcaldes mayores, and relatives in discretionary positions, along with a profitable involvement in the endemic evil of the Spanish Empire, in other words, contraband. ${ }^{124}$ In addition, the Jesuits accused them of neglecting to further the conquest, sending court procurators to denounce them in Madrid, ${ }^{125}$ but the visits,

\footnotetext{
122 Horst Pietschmann, "Burocracia y corrupción en Hispanoamérica colonial: Una aproximación tentativa," Nova Americana 5 (1982): 11-37, here 13.

123 Tomasso Campanella, La monarquía hispánica, trans. Primitivo Mariño (Madrid: Centro de Estudios Constitucionales, 1982), 77.

124 Pierre Bourdieu, Esquisse d'une théorie de la pratique (Paris: Éditions Droz, 1972).

125 For a study on the role of court procurators as primary mediators between the court of Spain and the Society of Jesus, see the work by Martínez-Serna, "Procurators and the Making of the Jesuits' Atlantic Network," 181-209.
} 
inspections, and ordinary juicios de residencia (trials of residence, the highest judicial review for Spanish officials during their term of office) failed to curtail the greed of the colonial officers. ${ }^{126}$ Far from being exceptional, illicit trade, bribery, favoritism, and the like became habitual administrative practices of each of the governors and captains of the islands, who, moreover, established important transoceanic trading networks centered on their diverse business interests. ${ }^{127}$

Graft and corruption in the Marianas were not so different from those in other frontier spaces in the Spanish Empire. In his thought-provoking 2008 article, Spanish historian Josep María Delgado calls attention to the fact that the politics of flexibility was one of the basic principles behind the organization and functioning of the imperial administrative structure. The well-known "obedience without compliance" argument was authorized by the Recopilación de leyes de los reynos de las Indias (Compilation of laws of the kingdoms of the Indies; law 24, tit. 1, lib. ii). It allowed for the defense of the (private) benefits of local administrators to the detriment of (public) metropolitan interests, which seldom coincided, while respecting the political authority of the monarch and his representatives (audiences, viceroys, governors, and captains general). ${ }^{128}$

In practice, the two principles-authority and flexibility-depended on a difficult balance between traditional (or patrimonial) powers and legalbureaucratic powers. This can best be appreciated in the difference between the men that occupied government posts in colonial societies. The common characteristic of these figures was that they had served the king. The crown directly adjudicated some rewards, posts, and emoluments of all kinds to friends or clients, but only some received offices by virtue of their capability or expertise. ${ }^{129}$ While the former practice was considered averse to what has

126 Brunal-Perry notes that the first ordinary trial or juicio de residencia in the Marianas took place in 1704 and involved de la Esplana, as ordered by the royal decree of February 14 of that same year (Brunal-Perry, "La legislación de Ultramar," 396-97).

127 Pietschmann, "Burocracia y corrupción en Hispanoamérica colonial," 31.

128 Onofre D. Corpuz, The Bureaucracy in the Philippines (Manila: Institute of Public Administration and University of the Philippines, 1957), 6o; John Leddy Phelan, "Authority and Flexibility in the Spanish Imperial Bureaucracy," cited in Josep Maria Delgado, "Caminando por la senda del atraso: Reformismo borbónico, cambio institucional y divergencia europea de España en la baja Edad moderna," in De Tartessos a Manila: Siete estudios coloniales y postcoloniales, ed. Gloria Cano and Ana Delgado (València: Publicacions de la Universitat de València, 2008), 171-208, here 179-80.

129 I have borrowed the terms "friends" and "clients" from the book by Víctor Peralta Ruiz, Patrones, clientes y amigos: El poder burocrático indiano en la España del siglo XVIII (Madrid: csic, 2006). 
been termed "distributive justice,"130 the latter constituted professional bodies whose loyalty diminished with respect to their distance from the centers of government, so that the crown did not exercise a vertical relation over the local jurisdictions. Power was therefore fragmented. In other words, a perversion in the political body favored improper conduct and deviations in the exercise of power, what Peruvian historian José de la Puente Brunke refers to as "bad greed" (mala codicia). ${ }^{131}$ "Bad greed" would also rear its ugly head in the history of the Mariana Islands, with dire consequences for the indigenous inhabitants.

One case in point was Governor Pimentel, whose great pride and haughtiness made him one of the most corrupt officials of the eighteenth century. Like his predecessor, the also Peruvian de la Esplana, Pimentel was a wolf to the Jesuits' lambs. His government was extraordinarily self-interested. He arrived in the Marianas on board the vessel Santo Domingo de Guzmán in August 1709 and took office within a month. Like de la Esplana before him, Pimentel moved out of the presidio and set up permanent residence in the villa of Humåtac palace, whence he managed his trading business, which depended on the arrival of the galleons and pataches from Manila. ${ }^{132}$

Like a good entrepreneur, Pimentel was not above engaging in commercial activities that could be established with any ship that happened to come close to the Marianas. On March 22, 1710, four English ships (Duke, Duchess, Marquis, and Batchelor) appeared on the coast of Pågu waving white flags. ${ }^{133}$

130 As Harro Höpfl observes, "distributive” justice means the allocation of burdens and punishments, as well as rewards, offices, and emoluments of all kinds, while "communicative" justice is concerned with relationships and conduct involving mutual obligations and/or rights, especially contractual or quasi-contractual relations (Harro Höpfl, Jesuit Political Thought: The Society of Jesus and the State, c.1540-1630 [Cambridge: Cambridge University Press, 2004], 284-85).

131 On the concept of mala codicia and its harmful effects on the operation of colonial bureaucracies, see José de la Puente Brunke, "Codicia y bien público: Los ministros de la Audiencia en la Lima seiscentista," Revista de Indias 236, no. 66 (2006): 133-48.

132 Driver, Cross, Sword, and Silver, 34. During Pimentel's administration, there were two royal houses or "palaces": one in Humåtac, built using masonry during the governorship of de la Esplana, and another, called "the royal palace" or palación, presumably in Hagåtña (Fr. Diego de Zarzosa's letter to procurator Fr. Antonio Jaramillo, Pågu, May 5, 1691, transcribed in Lévesque, History of Micronesia, 9:446). Driver notes that "palación would seem to imply a larger, more substantial, or a more important building, pointing to Hagåtña. At that time, the islands' only heavy artillery were some six cannons debajo del Real Palación, below the Royal Palace. Two bronze four-pounders, one iron four-pounder, and three twopounders made up the lot" (Marjorie G. Driver, El Palacio: The Spanish Palace in Agaña; A Chronology of Men and Events, 1668-1899 [Guam: Micronesian Area Research Center and University of Guam, 1984], 18; Driver, Spanish Governors, 10, 18-21).

133 AH CJC, Documentos manuscritos acerca de la historia de las Filipinas, FILPAS, no. 78, 1721, fol. $248^{\text {r. }}$. 
One of them, the Batchelor, was in fact the Spanish galleon Nuestra Señora de la Encarnación y Desengaño, captured with all its cargo by Captain Woodes Rogers (c.1679-1732) in Cape San Lucas, off the coast of Puerto Segura in New Spain, in January $1710 .{ }^{134}$

Upon their arrival at the port of Humåtac, Captain Rogers and his officers, in the name of Queen Anne Stuart of England (1665-1714, r.1702-7), entreated the Spaniards to provide them with food, refreshments, and all the supplies they considered necessary, under threat of razing the island to the ground along with its inhabitants. Quiroga set up a war council made up of retired or "reformed" officers, which debated the possibility of confronting the English. But instead of meeting with the council, Governor Pimentel wrote the foreign assailants a letter inviting them to peacefully stock up on whatever they needed..$^{135}$ Not only did he engage in contraband trading with the hostile captain but he also entertained the crew with gifts and an invitation to dine at the palace in Hagåtña. ${ }^{36}$

As historian Marjorie Driver has suggested, Pimentel was probably moved more by the prospect of future profit — avarice, ambition, or "bad greed" - than by any desire to defend the islands. ${ }^{137}$ This passivity and inaction in the face of an enemy brought him much criticism from the political and judicial authorities in Manila. In his defense, in 1712, Pimentel explained to Martín de Urzúa y Arizmendi, first count of Lizárraga (1653-1715), governor of the Philippines (in office 1708-15) and president of the Royal Audience, that the island lacked disciplined and trained personnel, as well as cannons, gunpowder, and the other necessary elements of war. Being thus totally defenseless, the war council

134 Antonio Gutiérrez, who was the ship's boatswain, was captured and sent to England as prisoner of war ("Governor Ursua Reports the Capture of the Almiranta Encarnación by English Pirates," Madrid, June 14, 1714, transcribed in Lévesque, History of Micronesia, 11:142-49).

135 AHCJC, Documentos manuscritos acerca de la historia de las Filipinas, FILPAS, no. 78, 1721, fols. $248^{\mathrm{r}}-25 \mathrm{0}^{\mathrm{r}}$. See also Barratt, Chamorros of the Mariana Islands, 224-25.

136 Barratt, Chamorros of the Mariana Islands, 217. In 1710, Pimentel had asked Philip v to order the construction of a fort with its respective defense batteries in the bay of Humåtac (Yolanda Delgadillo, Thomas B. McGrath, S.J., and Felicia Plaza, Spanish Forts of Guam [Guam: Micronesian Area Research Center (MARC), 1979], 40. See also the letter written by Governor Pimentel to Philip v on April 13, 1710, from Hagåtña, transcribed in Lévesque, History of Micronesia, 11:137. That same year, a huge typhoon sent mammoth waves against the island's western shores, inundating the fort of Santa María de Guadalupe, built in 1683 by Governor Don Antonio de Saravia (AGI, Filipinas, leg. 94, fol. 14, cited in Delgadillo, McGrath, and Plaza, Spanish Forts of Guam, 10; Rogers, Destiny's Landfall, 77).

137 Driver, El Palacio, 18. 
constituted in the town of Agat decided not to attack the English squadron. ${ }^{138}$ However, this explanation did not convince the oldest magistrate (decano), José Torralba (1653-1726), who stepped in as governor of the Philippines (in office 1715-17) after the death of Governor Lizárraga. During this state of misgovernment, Pimentel left Manila for Guåhan, but right after his arrival, Torralba sent Pimentel back to Manila in chains. ${ }^{139}$

That he failed to fulfill his duty as soldier and caudillo was the most serious charge brought against Pimentel at the inquest that was opened in the Philippine capital on January 23, 1712. ${ }^{140}$ Captain José Ruiz López (dates unknown) was the designated inspector (veedor or juez pesquisidor) in the investigation of Pimentel, who by then was seventy-six years old. The Audience of Manila also initiated a series of inquests against Pimentel on July 8, 1712 for having established trade relations with Captain Woodes Rogers in $1710 .{ }^{141}$ Notwithstanding the aged governor's alleged ignorance of any war between Spain and England, on July 24, 1714 he was sentenced to prison and the tribunal ordered a juicio de residencia (judgment of residence). ${ }^{142}$ As historian Charles Henry Cunningham has noted, "Pimentel had not only to stand investigation for the particular act which had brought about his removal, but he was also subjected to a residencia covering his entire career as governor."143

From the beginning, Pimentel's relations with the Jesuits had been difficult, but they worsened around 1715 owing to his excesses with the natives and his

138 AHCJC, Documentos manuscritos acerca de la historia de las Filipinas, FILPAS, no. 72, 171218 , fols. $64^{\mathrm{r}}-65^{\mathrm{v}}$.

139 Cunningham, Audiencia in the Spanish Colonies, 127.

140 The Royal Audience of Manila initiated a series of inquests against Governor Pimentel on July 8, 1712 for having welcomed English corsair Woodes Rogers in 1710 and establishing trading relations with him (Council of Indies' letter to King Philip v, June 14, 1712, in AGI, Ultramar, 561. See also AHCJC, Documentos manuscritos acerca de la historia de las Filipinas, FILPAS, no. $72,1712-18$, fols. $62^{\mathrm{r}}-72^{\mathrm{r}}$ ). To handle future attacks, the king dictated a royal provision on July 24,1712 , which ordered the dispatch of armed units to the Philippines and Marianas (AGN, Gobierno Virreinal-Cédulas Reales y Duplicados (100)—Reales Cédulas Originales—vol. 35-Ex 98, fols. $1^{\mathrm{r}}-7^{\mathrm{v}}$ ).

141 "Expediente seguido en Manila y enviado al Consejo de Indias contra el gobernador de las islas Marianas, don Juan Antonio Pimentel sobre la buena acogida que dio en aquellas islas a los enemigos piratas ingleses que llegaron a aquellas islas con la presa de la nao almiranta" (AGI, Audiencia de Manila, Manila, July 8, 1712, in AHCJC, FILPAS, no. 72, fols. $\left.62^{\mathrm{r}}-72^{\mathrm{r}}\right)$.

142 The highest judicial procedure of Castilian law and the laws of the Indies for Spanish officials at the termination of their terms of offices. This judgment was largely an automatic procedure in the Americas and the Philippines.

143 As Cunningham has observed: "There were two kinds of investigations of official conduct, one taken at the completion of the regular term of office and the other at any time when the needs of the service required it" (Cunningham, Audiencia in the Spanish Colonies, 128). 
own behavior that the Jesuits considered licentious and unnatural. In his annual letter of 1715, Fr. Felipe María Muscati (1656-1739) still praised the governor, who had begun renovation of the Society's house and church, describing how "said governor not only goes as overseer of the work, but as if he were a peon carrying the building materials with great pleasure and no lesser edification for those who see him perform these humble acts."144 However, sympathy would soon become hostility after the 1718 arrival of Cantova, who was openly critical of the scandalous activities of the governor, particularly those resulting from his lust and greed. ${ }^{145}$

On March 8, 1717, Pimentel decided to reorganize the population in the archipelago, hoping to reverse the alarming demographic collapse. The Jesuits were not enthusiastic, but they were forced to follow suit due to his violent character. Pimentel named his grandson and deputy, Captain José Bonifacio Argüelles (dates unknown), visitador (inspector) of all the partidos on Guåhan, but nothing came of this because of the diminishing native population. ${ }^{146}$ In May 1719, soon after arriving on Guåhan, Italian Fr. Giuseppe Bonani (dates unknown) confirmed the disheartening scenario. There had been around eight thousand in 1669 on the main island; now there were only eight hundred, and of the four thousand Chamorros that had populated Rota in its better days, there were now only 344. Together, the population of these islands plus that of

144 ARSI, "Algunos puntos para la Anua de esta misión Mariana," Supplementum ad Historiam, $1584-1750$, tomo 14 , fol. $105^{\mathrm{v}}$. This letter is transcribed in Lévesque, History of Micronesia, 11:637-43.

145 At that time, there were nine priests in the Marianas: Fr. Felipe María Muscati, viceprovincial and minister in the partido of Inarajan; Fr. Miguel de Aparicio, rector of the school of San Juan de Letrán and minister in Hagåtña; Fr. Lorenzo Bustillo in the partido of Humåtac; Fr. Diego de Zarzosa (1648-1741) in the partido of Agat; Fr. Johann Schirmeisen (d.1719) in the partido of Merizo; Fr. Ignacio de Ibargüen, minister of Indians; Fr. Pedro Cruydolf and Fr. Joseph Bloast; and three coadjutor brothers: Br. Jaime Chavarri, doctor and apothecary; Br. Nicolás Montero, domestic assistant in the residence; and $\mathrm{Br}$. Luis García, assistant in the children's school (ARSI, "Algunos puntos para la Annua de esta misión Mariana," Supplementum ad Historiam, 1584-1750, 14:fol. 104 ${ }^{\mathrm{r}}$ ).

146 The rise of Joseph Bonifacio Argüelles through the ranks of officialdom was meteoric, epitomizing the prevalence of favoritism and nepotism in Pimentel's administration. On November 18, 1715, Argüelles was named company lieutenant or alférez of the Spanish infantry under the command of Pimentel (the other unit was commanded by Joseph Bonifacio's brother, Captain Juan de Arguelles Valdés). On December 5, 1715, he was named captain of said company, and he remained as such until June 6, 1716, when he became the island's secretary of war and government. On December 31, 1715, Pimentel named him his deputy lieutenant or lugarteniente, which carried a salary of thirty pesos a month. On March 8, 1717, he was named visitator of the partidos of Guåhan, and on August 26, 1717, he was made sergeant major of the vessel Santo Domingo de Guzmán, which that year had brought the situado from the Philippines to the Marianas ("Relación de méritos de don Joseph Bonifacio de Argüelles," AG I, Filipinas 118, no. 9). 
Saipan did not add up to more than five thousand Chamorros, who, moreover, subsisted in a general state of misery. ${ }^{147}$

In a letter written on July 19, 1718 from the village of Capul, in northern Samar (Philippine Islands) by the Spanish missionary Marcelo de Valdivieso (dates unknown) to Juan Marín, the general's assistant for the Spanish provinces, the Jesuit priest accused Pimentel of being directly responsible for the decline in the Chamorro population. ${ }^{148}$ According to Valdivieso,

there is no stopping or moderating the injustices and damages [committed by the governor] against those poor recent converts, and so that is notably retreating. And the Indians, frustrated at seeing themselves laden with such heavy slavery, do things that are unworthy of the faith they profess. If the poor fathers want to remedy this by recurring to [striking them with] the hand, they are scorned or ignored, or they are threatened with banishment, and so they are forced to suffer more than they did at the beginning of the conquest of those islands, for then with a lance their travails were ended, and today with so much grief and hardships their martyrdom lasts many years. ${ }^{149}$

Sergeant Major Quiroga expounded the reasons for the moral and material decadence of the Marianas in a letter to Philip v on May 26, $1720 .{ }^{150}$ At first, he wrote, the obstinate adherence of the Chamorros to their pagan rites had provoked the wrath of God, manifested in epidemics, typhoons, and storms. ${ }^{151}$ However, the intervention of the Jesuit priests in recent years had been providential and, as a result, most of the population had become resigned to their presence. In fact, Quiroga and Valdivieso agreed in their analysis of what had caused the islands' deleterious situation. For both men, spiritual poverty had less to do with the conduct of the natives and more to do with the immorality

147 Fr. Joseph Bonani's letter to Fr. Giacomo Pettinati (or Pethnati), rector of the Jesuit school in Agram (Zagreb), Croatia, May 27, 1719 (AHCJC, FILCAR E.I, a-18. 1677-1750, part 1, 16771735, E.I. a-18/1, fols. 104-6, 111).

148 Richard J. Shell, Proas in the Marianas (1668-1742) (Mangilao, Guam: MARC and University of Guam, 1992).

149 Fr. Marcelo Valdivieso's letter to Fr. Juan Marín, "Acerca de los medios de aumentar la poblada de Marianas y Mindanao (1718)," fols. $2^{\mathrm{r}}-2^{\mathrm{v}}$, in "Diversas sobre islas Marianas y Carolinas/Sanvitores" (AHCJC, FIL HIS-061, E.I, c-05/4/5 [1768]; RAH, Cortes 567, bundle 12). My translation.

$15^{0}$ This letter is in AGI, Filipinas 95, fols. 18-33, and AGI, Ultramar 582, fols. 1515-29. It was published in Driver, "Notes and Documents," 98-106.

151 In 1711, a deadly epidemic swept throughout the islands, and it affected the Spanish population more harshly (AHCJC, Documentos manuscritos acerca de la historia de las Filipinas, FILPAS, no. 78 , 1721, fol. $238^{\mathrm{v}}$ ). 
and corruption of the Spanish and Filipinos, who, in the words of Valdivieso, were "blind with greed, enslave the Indians and the soldiers, and they even want to hold the ministers of God subject to their will, with the very grave consequences that arise from this." ${ }^{\prime 152}$

First, Quiroga accused the elderly governor of being a libertine and keeping girls and women at his palace, scandalous behavior that was talked about in Manila. Pimentel, "being a man of age and with no wife," was notorious for keeping these young women as concubines and even offered them as wives to the soldiers in the presidio in exchange for their loyalty. Some of the women, however, continued to live in what became known as the "Great Turk's seraglio" even after they married. ${ }^{153}$ The governor acted as a de facto feudal lord who demanded sexual favors from "his women" and forced them to commit adultery, raping and abducting those he wanted. According to Quiroga, many soldiers became indebted for life to the governor, who controlled and distributed the royal situado with the help of his relatives. In addition, those who opposed such practices saw their opportunities to rise to the position of captain or alféreces (lieutenants) disappear; some lost their posts, others their lives. ${ }^{154}$ Pimentel similarly coerced the Chamorros, whom he accused of informing the Jesuit priests about these so-called scandals. Apparently, Quiroga was not entirely wrong about the widespread state of corruption. So as not to cross or offend Pimentel, many Chamorros stopped sending their children to the Jesuit school of San Juan de Letrán and some stopped going to church altogether. ${ }^{155}$ Indignant, the priests denounced Pimentel's faults from the pulpit, which angered the governor. ${ }^{156}$

Lastly, Quiroga accused Pimentel and his retinue of indiscriminately exploiting the few surviving Chamorros, making them work for months in private lucrative businesses in exchange for a few tobacco leaves a day. ${ }^{157}$ The effective exploitation of the islands' resources was never among the priorities

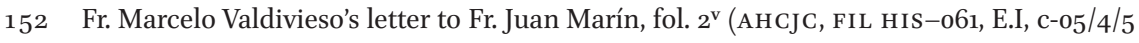
[1768]. See also Driver, "Notes and Documents," 106).

153 AG I, Ultramar 561 (II), no. 2, fols. 11v; A I I, Filipinas 99, fol. 58, cited in Driver, El Palacio, 18; Quiroga's letter to King Philip v, May 26, 1720, cited in Driver, "Notes and Documents," 105. It is also transcribed in Lévesque, History of Micronesia, 12:161-67.

154 Driver, "Notes and Documents," 105.

155 Fr. Víctor Walter's (or Valdés's) letter to Fr. José Calvo, general procurator, Hagåtña, 1736, cited in Maritza R. del Priore, "Education on Guam during the Spanish Administration from 1668 to 1899 " (PhD diss., University of Southern California, 1986), 35-36.

156 Quiroga's letter to King Philip v, May 26, 1720, cited in Driver, "Notes and Documents," 105.

157 Ibid., 102. In 1718, Valdivieso made these same accusations against the excesses and bad example set by Governor Pimentel (Fr. Marcelo Valdivieso's letter to Fr. Juan Marín, fols. $2^{\mathrm{v}-} 3^{\mathrm{v}}$, in AHCJC, FIL HIS-061, E.I, c-05/4/5 [1768]). 
of the Spanish monarchy and, indeed, the crown did not demand tribute from the native inhabitants of the Marianas because it considered them too poor to pay. They were also spared the repartimientos de mercancías (forced sales of goods) that the Spanish successfully imposed in the Philippines and elsewhere in the empire as an extrajudicial form of tribute collection. ${ }^{158}$ However, the Spanish governors, alcaldes, and infantry captains-especially Pimentel's grandchildren, Bonifacio de Argüelles and Juan de Argüelles Valdés (dates unknown), both of whom occupied these offices "in consideration of the integrity and zeal of their royal service" - used their positions to benefit illegally from the work of those same men and women who were too poor to contribute to the royal treasury, exacting "contributions" for their private coffers. ${ }^{159}$

Despite the desperate decline in the Chamorro population, Governor Pimentel did not consider transferring them to the Philippines, as Governor Medrano had suggested during his four years at the helm beginning in 1700. What Pimentel did instead was to even more intensely exploit the remaining natives for his own benefit. The Chamorros were forced to produce rice, corn, melons, beans, as well as the highly prized capers and firewater or aguardiente, which Pimentel and his acolytes sold at exorbitant prices in the markets of Manila, but also in a tienda abierta, a store located on Guam, often to the very natives who produced it, as well as to the soldiers in the presidio. ${ }^{160}$ In addition, Filipino natives and soldiers were responsible for introducing lambanog, an alcoholic beverage made from coconut, locally known as tuba, aguyayente, or aguardiente. The Spanish authorities forced the Chamorro people to produce the lambanog, to which they became addicted and, consequently, unwilling to work. In response, the Spanish banned production of the drink.

Quiroga undoubtedly knew what he was talking about. He had been sergeant major for more than thirty years, and he had suppressed many a Chamorro revolt. But he had also struggled against the uprisings of the Spaniards under his command. The soldiers in the presidio were usually young amnestied convicts who signed up "voluntarily" for military service in the Philippines or former convicts along with vagabonds who had run away from New Spain, and who engaged in all sorts of disturbances when they reached the Marianas, "returning the islands to their previous state of sin and moral misery, extorting and abusing their inhabitants." ${ }^{161}$ In 1720, Quiroga argued that these "bad

158 Álvarez, "Repartimientos y economía en las islas Filipinas," 170-216.

159 Quiroga's letter to King Philip v, May 26, 1720, cited in Driver, "Notes and Documents," 101-2; Hezel, From Conquest to Colonization, 41; Driver, Cross, Sword, and Silver, 102.

160 Driver, Cross, Sword, and Silver, 101-2.

161 Quiroga's letter to King Philip v, May 26, 1720, cited in Driver, "Notes and Documents," 1034; Lévesque, History of Micronesia, 12:161-67. See also Hezel, From Conquest to Colonization, 
Spaniards" were subverting the labor of "God's angels" - which was how he referred to the Jesuits—and returning the islands to Satan's domain. ${ }^{162}$

Hoping that the king as sovereign judge could remedy this situation, the Jesuits wrote a memorial in 1722 to Philip v, asking him to put an end to the miseries suffered by the native inhabitants of the Marianas and missions of Mindanao at the hands of their greedy governors. Since the Chamorros had significantly diminished in number as a consequence of war and epidemics, so too had the labor that could have generated wealth or some kind of return. The Philippine authorities, along with the Jesuit superiors, began considering a reduction in the number of soldiers in the presidio, which would save a considerable sum of money on an annual basis that could be diverted to other presidios, such as the one in Zamboanga, which was reestablished in 1718 to protect the Jesuits stationed at the new missions in Jolo and Tamontaca. Using the presidio at Zamboanga as their home base, the Jesuits longed to convert the Muslim populations farther inland. However, not enough missionaries were available, and as a result, in the following years some prominent procurators, such as Jesuit José Calvo (1681-1757), suggested the gradual abandonment of the Mariana Islands because of their scarce population, proposing instead that a relocation of Guåhan's Jesuits would benefit the spiritual conquest of the new frontier of Christendom located farther south. ${ }^{163}$

The Jesuits complained that if a priest protested in favor of the natives, he was scorned or threatened with deportation. In the Marianas, Ibarguen, vice-provincial and commissar of the Holy Office, and Cantova, rector of the

33-34. On the topic of forced migration in the Spanish Pacific, see the seminal work of María Fernanda García de los Arcos, Forzados y reclutas: Los criollos novohispanos en Asia, 1756-1808 (Mexico City: Potrerillos Editores, 1996). More recently, see Stephanie Mawson, "Unruly Plebeians and the Forzado system: Convict Transportation between New Spain and the Philippines during the Seventeenth Century," Revista de Indias 73, no. 259 (2013): 693-730; Eva Maria Mehl, Forced Migration in the Spanish Pacific World: From Mexico to the Philippines, 1765-1811 (Cambridge: Cambridge University Press, 2016).

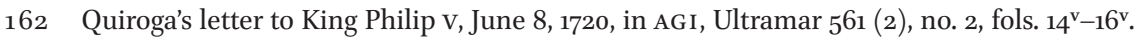
See also Lévesque, History of Micronesia, 12:159-61. Quiroga bequeathed many of his possessions to the Jesuits to compensate for this perversion, specifically to the San Juan de Letrán school (Driver, Spanish Governors, 22).

163 In his two briefs dated November 1745, Fr. José Calvo (1745, transcribed by Lévesque, History of Micronesia, 13:587-95), procurator of the Society of Jesus, strongly recommended the urgent reform of the Marianas' presidio. Likewise, he stressed the need to establish a permanent Jesuit and Spanish presence in the Muslim sultanates of Maguindanao and Jolo (RAH, Cortes 567, legajo 9/2674; cf. Calvo [1745]). A forthcoming study on these two briefs can be found in Alexandre Coello de la Rosa, "Políticas geo-estratégicas y misionales en el sur de Filipinas: el caso de Mindanao y Joló (siglo Xviri)” (Revista de Indias, in press, 2019). 
boys' school, suffered the consequences of Governor Pimentel's greed; they were exiled to Humåtac in 1715, whence they could no longer denounce him in their sermons. ${ }^{164}$ The 1722 memorial also criticized Pimentel for taking over the Indians' lands and forcing them to work in his private enterprises on a daily basis, exacerbating the collapse of the population and the ruin of Christendom. ${ }^{165}$ Finally, they asked the king to grant the fathers at the San Juan de Letrán school a plot of land for their crops and cattle, because some administrators, like Pimentel himself, had taken land from them. ${ }^{166}$

The situation in the Marianas did not seem to improve under a new governor, Sánchez de Tagle, whose behavior did not significantly differ from that of his predecessor. ${ }^{167}$ Like Pimentel, Sánchez de Tagle was controversial from the very beginning. On July 2, 1724, the bishop of Cebu complained to the judges or oidores of the Audience of Manila that the governor had not provided the legal and necessary dues to enable the natives' annual confession and Communion, "with the consequent irreparable loss of souls."168 In another letter to the Royal Audience written on June 8, 1724, Muscati, vice-provincial of the Marianas mission, was more vehement in his denunciations of the abuses and extortions suffered by the natives. These accusations concerned not only the governor but also alcaldes and mayordomos (overseers) like Sergeant Major Pedro de Sandoval (dates unknown) who, having the power to remedy and punish the disorders and scandals committed in the districts of Merizo (Meriso or

164 José Quiroga (1720), cited in Hezel, From Conquest to Colonization, 49.

165 "Memorial de los indios de las islas Marianas y de Mindanao (Filipinas) al rey [Felipe v], para que ponga remedio a los agravios que sufren por parte de su gobernador" (Sección Nobleza del Archivo Histórico Nacional, Osuna, C. 387, D. 31, fols. $1^{\mathrm{v}}-2^{\mathrm{r}}$ ). This brief reached the king on March 30, 1722, who then dispatched a copy to the archbishop of Manila (AGI, Filipinas, 333, book CC 12 , fols. $252^{\mathrm{v}}-254^{\mathrm{r}}$ ).

166 Valdivieso's (1718) letter to Marín, dated July 19, 1718, stated that "a plot should also be destined for the school of the fathers so that they tend their crops and raise some cattle for their livelihood, for even this the governor has taken from him, even though the fathers brought with them some animals from Mexico of the kind that abound in those lands" ("Real Cédula sobre lo representado por los indios de Marianas y Mindanao que incluye la copia adjunta del Memorial de dichos indios," AGI, Filipinas 528 , fols. $1^{\mathrm{v}}-2^{\mathrm{r}}$ ).

167 On June 5, 1724 in Manila, Sergeant Major Joseph Ruiz declared that he "had no true or finite thing to say against Captain Don Luis de Tagle regarding the punto de agravios because he only heard rumors of complaints about the harshness of said Governor Tagle" (Lévesque, History of Micronesia, 12:590. My italics). For more information on the government of Sánchez de Tagle, see "Informe de la Audiencia de Manila al rey, con fecha en Manila, July 1, 1726," in AGI, Ultramar, 561, cited in Lévesque, History of Micronesia, 12:500-4.

168 Bishop of Cebu's letter to the Royal Audience of Manila, Manila, July 2, 1724 (AG I, Ultramar, 561, cited in Lévesque, History of Micronesia, 12:508-9). 
Malesso) and Humåtac, were the ones who most scandalized, obstructed, and destroyed the spiritual well-being of the souls. ${ }^{169}$

The operating and business processes of global trade networks were tightly linked to the development of other networks at the local level. It was impossible to isolate the development of local production from global exchanges. Towns or partidos were like taifa fiefdoms where unrestrained mayordomos behaved like feudal lords, abusing their authority and exploiting the natives' labor for their own economic benefit, forcing them to tend their private crops of rice and corn three or four days a week without pay or sustenance. An authoritarian and despotic ruler, Sánchez de Tagle was involved in trade businesses with some of his relatives, such as the wealthy Mexico City almacenero (grocer) Pedro Sánchez de Tagle (1661-1723), and Juan Manuel Pérez de Tagle (dates unknown) in Manila. ${ }^{170}$ Not surprisingly, Governor Sánchez de Tagle's "bastardly love" regarded the Marianas as his private preserve for making money, using his family connections to reinforce a transpacific trade empire. ${ }^{171}$

The Audience of Manila responded on July 25, 1725 by ordering Sergeant Major Manuel Díaz de Dozal (dates unknown) to take the situado to the Marianas and deliver two royal dispatches to Sánchez de Tagle accusing him of misappropriation and prevarication. ${ }^{172}$ Upon his arrival, Dozal's inspections confirmed Muscati's complaints regarding the oppression of the natives. Not only was Sánchez de Tagle physically violent in his treatment of the natives but the governor also used women for all kinds of physical work. ${ }^{173}$

Sánchez de Tagle's actions demonstrated not just how difficult it was for the political state to control the excesses of its representatives but how incapable it was of channeling these men's energies toward charity, love, and the common good. ${ }^{174}$ On October 27, 1724, Dozal went to the governor's palace to personally deliver the royal provisions. Sánchez de Tagle, however, not only refused to receive the dispatches; he also ordered the immediate arrest of commissary Dozal, mistreating him "in word and deed" for refusing to recognize the governor as supreme authority, before transferring him as a prisoner to the

169 Atienza, "Priests, Mayors and Indigenous Offices," 39.

170 Carmen Yuste López, Emporios transpacíficos: Comerciantes mexicanos en Manila (17101815) (México: Universidad Nacional Autónoma de México, 2007), 126, 131-33.

171 I have borrowed the term "bastardly love" from Pablo Fernández Albaladejo, Materia de España: Cultura política e identidad en la España moderna (Madrid: Marcial Pons Historia, 2007), 212.

172 “Real Provisión," Manila, July 25, 1724 (AGI, Ultramar 561, transcribed in Lévesque, History of Micronesia, 12:516-17).

173 "Informe de la Audiencia de Manila a Felipe V," Manila, July 1, 1726. AG I, Ultramar 561, transcribed in Lévesque, History of Micronesia, 12:501-2.

174 Fernández Albaladejo, Materia de España, 197-244. 
vessel Nuestra Señora de la Soledad, where he remained under the custody of Corporal Juan del Hoyo (dates unknown). ${ }^{175}$ Dozal spent four days aboard the ship before finally deciding to return to Manila with the unopened dispatches, fearing an attempt on his life. Indeed, when Dozal once again set sail for the Marianas in late December 1724, accompanied by Jesuit Antonio Masbesi (1697-?), chaplain of the vessel Nuestra Señora de los Dolores, he had to leave Guåhan immediately under fire from the cannons at the port of Merizo. ${ }^{176}$

The Jesuits wrote several letters and briefs to the Royal Audience of Manila and the marquis of Casa Fuerte, Juan de Acuña y Bejarano (1658-1734), viceroy of New Spain from 1722 to 1734, insisting that if the stability of the remote and forlorn Mariana Islands was to be guaranteed, the safe arrival of ships from the Philippines and other parts of the Indies had to be secured. In 1721, Sánchez de Tagle was still building Fort Santiago at the tip of the Orote Peninsula, monitoring the possible arrival of enemy ships at the harbor at Apra (or Humåtac), and elsewhere on Guåhan. He successfully drove off Captain John Clipperton's (1676-1722) vessel, the Success, when terms could not be agreed upon regarding the exchange of arms and ammunition for water and food. On May 28, Clipperton attacked the Spanish ship San Andrés when it was at anchor, prompting Spanish soldiers to fire upon the enemy from the uncompleted fort. ${ }^{177}$

In 1722, to reinforce Guåhan's defenses, Sánchez de Tagle removed all artillery, gunpowder, candles, and rigging from the pataches sent from the Philippines to equip three ships he had at the port of Merizo. ${ }^{178}$ The last ship seized was the Santo Toribio, from which he removed cannons, munitions, and various supplies. This habitual practice of the governor impeded the necessary provisioning of the islands, and for it Sánchez de Tagle's days as governor were numbered. In response to the rampant immorality that characterized the islands' social and political life, the Jesuits recommended that a dozen virtuous families from the Philippines or Mexico settle on the islands, so as to teach the children good customs "as well as the other exercises of civil life

\footnotetext{
175 “Declaración del cabo Juan del Hoyo," Merizo, December 24, 1724 (AGI, Ultramar 561, cited in Lévesque, History of Micronesia, 12:520-21).

176 "Declaración del comisario Díaz de Dozal," Manila, February 9, 1725 (AGI, Ultramar 561, transcribed in Lévesque, History of Micronesia, 12:533-36). A similar event took place in 1723, when the governor ordered fire on the vessel Santo Toribio heading for Manila, with the intention of sinking it for no apparent reason (Lévesque, History of Micronesia, 12:502, $528,536)$.

177 Delgadillo, McGrath, and Plaza, Spanish Forts of Guam, 27-28.

178 "Declaración del comisario Díaz de Dozal," Manila, February 9, 1725 (transcribed in Lévesque, History of Micronesia, 12:535).
} 
ignored by the barbarians."179 However, this could not be carried out without "well-intentioned men" who, in the words of Friar Benito Jerónimo Feijóo y Montenegro (1676-1764), demonstrated an aptitude for politics and good government:180 a model patriot, a "man of courage and experience and a good Christian" who would set an example for the soldiers of the presidio, "because the men in this part of the world differ little or none at all from brutes in their savagery and vices of the flesh."181

On May 24, 1723, the viceroy of New Spain visited the Jesuit procurator Agustín Soler $\left(1675^{-1738)}\right.$ to corroborate the veracity of the Jesuit priests' claims regarding the situation in the Marianas. ${ }^{182} \mathrm{He}$ then wrote to the king and told him that disturbances and affronts had indeed occurred, but that "the remedy has already been set in place [...] changing the person who governed and appointing another with instructions conducive to cease the damages that have been known to operate until then."183 He meant, of course, Sánchez de Tagle, whom the Royal Audience of Manila accused in 1725 of treason and lèsemajesté for abandoning his post on December 20, 1724 when he went to the Philippines without permission and stayed in the sanctuary of the church of San Sebastián. ${ }^{184}$

Toribio José de Cosío y Campo, marquis of Torre-Campo and governor and captain general of the Philippines from 1721 to 1729, named Manuel de Argüelles y Valdés, a resident of Manila, interim governor of the Marianas (in office 1725-30), "for I have been satisfied with his good proceedings in the employments that he has held in these islands in the service of Your Majesty and because he garnered prudence and disinterest in the very government of the Marianas which he already held as interim governor."185 On July 18, 1725,

179 “Declaración del capitán Juan de Miranda, piloto mayor," Manila, February 20, 1725 (transcribed in Lévesque, History of Micronesia, 12:543-46). See also AG, Filipinas 99, fols. $33^{\mathrm{r}}-34^{\mathrm{v}}$.

180 Benito Jerónimo Feijóo, Teatro crítico universal (1729), cited in Fernández Albaladejo, Materia de España, 220.

181 "El principal medio para la estabilidad y aumento de la cristiandad de Marianas," RAH, Fondo Cortes, 567, 9-2676, doc. 1 , fol. $1^{\mathrm{r}}-1^{\mathrm{v}}$ (n.d.).

182 Sommervogel, Bibliothèque de la Compagnie de Jésus, 8:1354.

183 Viceroy of New Spain's letter to the king, Mexico, May 24, 1723 (Lévesque, History of Micronesia, 12:574-77). According to various witnesses, Governor Sánchez de Tagle was afflicted by a multiple paralysis that impeded all movement and speech (Lévesque, History of Micronesia, 12:639-40).

184 "Traslado auténtico de la Real Cédula en la que se previene a esta Real Audiencia de cuenta de lo determinado en las causas del capitán Luís Antonio Sánchez Tagle, gobernador que fue de las Marianas" (1730) (AGI, Filipinas 530, fols. $15^{\mathrm{r}}-16^{\mathrm{v}}$ ).

185 AGI, Filipinas 41, no. 5 . 
a patache with nine people aboard set sail for the Marianas, one of whom was Lance Sergeant (cabo superior y sargento) Manuel de Herrera (dates unknown), named lieutenant general by the Audience of Manila until the arrival of Governor Argüelles, the son-in-law of Pimentel. ${ }^{186}$

During this second administration, Argüelles agreed with Quiroga on the need to reduce the military personnel in the presidio. In his opinion, the maintenance of lands where barely seven hundred Chamorros lived did not require the presence of so many soldiers and missionaries. Without natives, the office of governor became increasingly less attractive, for there were no laborers to exploit in agricultural enterprises. Argüelles thus revived the old project of Governor Medrano, which propounded the progressive abandonment of the islands. The essence of this project was, in fact, consonant with the Bourbon reforms, which sought to increase the efficiency of the exploitation and use of the empire's resources. However, the will to modernize the American and Asian possessions behind the reforms did not always successfully translate into practice. Argüelles remarked, for instance, that the royal cedula of March 30, 1722 (which overrode that of December 30, 1687) had ordered eighty to ninety families to come in the patache that brought the situado from Manila for the purpose of repopulating the Mariana Islands, but this had not been carried out. ${ }^{187}$ On the other hand, Argüelles argued, the number of Chamorros had continued to decline in recent years, and in order to guarantee the financial viability of the islands, it was necessary to reduce the 130 soldiers in the presidio-integrated into three companies, two Spanish and one Pampangato twenty-five, with a monthly salary of five pesos each, and one lance corporal with a monthly salary of twenty-five pesos. This would save the royal treasury more than half of the twenty thousand pesos that it was currently spending on annual funding for this royal presidio. ${ }^{188}$ Some Jesuits, like Cantova, agreed that the number of missionaries could be reduced to three once all the natives were concentrated on the island of Guåhan in Hagåtña and Humåtac. ${ }^{189}$

186 A copy of the "Instrucciones que ha de observar don Manuel de Argüelles y Valdés en el gobierno de las islas Marianas" is available in AHCJC, FILHIS-o61. E-I-c5 [r] Cuadernillo "Muerte de Felipe v y coronación de Fernando VI (1747) en Agaña Marianas," fols. $28^{r}-30^{r}$. Pimentel's daughter, Maria Rosa Pimentel, had married Manuel de Argüelles y Valdés, making him not just the future governor of the Marianas but also his son-in-law and political ally. On December 15, 1720, one of the couple's sons, Manuel Joseph Bonifacio de Argüelles, wrote a "Relación de Méritos" requesting the office of governor of the Marianas (AGI, Filipinas 118, no. 9).

187 AGI, Ultramar 562, fols. 45-48, cited in Hezel, From Conquest to Colonization, 59.

188 Governor Argüelles's letter to the Royal Audience of Manila, Hagåtña, April 24, 1726 (AGI, Ultramar 561, bundle 20; transcribed in Lévesque, History of Micronesia, 13:46-48).

189 AGI, Filipinas 141, no. 22. See also Hezel, From Conquest to Colonization, 54-56. 
An official census taken in December 1727 showed a Chamorro population of 2,279, confirming a continuing demographic decline. ${ }^{190}$

However, although he recommended reducing the number of missionaries and soldiers in the presidio, Argüelles warned about the danger of leaving the Marianas without sufficient defense, for they were "the throat through which to reach the main body of these islands [the Philippines] for their conservation." His main concern regarding the "reduction of infantry, corporals, and officials in said islands" was, in fact, that pirates or corsairs could take shelter there to surprise and attack the galleons on their way from Acapulco. ${ }^{191}$ His opinion thus coincided with that of his father-in-law, Pimentel, who had criticized the fact that on most islands, the coves were open and undefended, lacking forts and castles. ${ }^{192}$ Both governors, Pimentel and Argüelles, were involved in trans-Pacific trade along with Mexico City's almaceneros, whose trade activities escalated throughout the eighteenth century.193

\section{New Spiritual and Geopolitical Configurations}

Why, then, did the Spanish crown decide to keep such seemingly marginal and costly islands? The provincials in Manila kept sending procurators to the curia in Rome and Madrid hoping to reduce or close the Marianas mission. Their dependence on civil powers as well as their relative failure in the archipelago had impeded their plans to send missionaries to other fronts, especially the islands of Mindanao and Sulu, where they could cultivate more productive "spiritual gardens" among the southern Muslims. Although Governor Sabiniano Manrique de Lara (in office 1653-63) had decided to remove the Spanish forces from southern Mindanao and concentrate them in Manila in 1665, deserting the Christians who lived there, the order's superiors were willing to defend

\footnotetext{
190 "Traslado auténtico de los autos sobre la consulta del general don Manuel de Argüelles, gobernador de las islas Marianas, en que da cuenta del estado en ellas por haberse retirado los administradores de los cinco partidos y el que quedó en lugar del capitán don Luis Antonio Sánchez de Tagle. Año de 1727" (AGI, Filipinas 141, no. 22; AG I Ultramar 561, leg. 20, fols. 124, cited in Driver, El Palacio, 22; Hezel, From Conquest to Colonization, 16).

191 On July 13, 1728, the Council of the Indies declared that it had received the letters of the marquis of Torre-Campo, governor of the Philippines, regarding the suggested reduction in the military in the Marianas, without making a declaration regarding the matter (AGI, Filipinas 95, fols. $1^{\mathrm{r}}-2^{\mathrm{r}}$ ).

192 AGI, Filipinas 141, no. 22.

193 Yuste López, Emporios transpacíficos, 412, 446.
} 
the Christian community at all costs, even to the detriment of the Marianas' faithful. ${ }^{194}$

Certainly, there was little interest in the Mariana archipelago, especially since there were practically no possibilities of increasing its Spanish population or establishing commercial relations with China or Southeast Asia from there. The Marianas were not the Spice Islands; they had little potential for agricultural development and they lacked mineral resources. Thanks to the Jesuits' successful pressure on the Philippine authorities, Cantova was allowed to make one last trip to the Caroline Islands, notwithstanding the fact that the Philippine governors were far more preoccupied with strengthening the Spanish position vis-à-vis the corsairs in the south than colonizing a "new Philippines." 195

In this context, Jesuit superiors suggested that the Marianas and islands south of them might serve as stepping-stones to take their missionary activities on to other, more promising islands. ${ }^{196}$ As historian Ines G. Županov has observed, for the Jesuits, the Eastern horizon constituted "a concrete utopia, a fabulous place of possibilities and projects" where they could establish the universal Christianity that had failed in the Old World of Europe. ${ }^{197}$ As a result, the Jesuits no longer deemed the archipelago a worthy mission, and they hoped that the crown would, in fact, abandon the islands and dedicate itself to exploring new spiritual frontiers in the Philippines or securing those that were yet unconquered.

The role played by the missionaries, provincials, and procurators of the Society of Jesus is demonstrated by the continuous, risky, exploratory, and/

194 From the Zamboanga presidio on the island of Mindanao, the Spanish, assisted by the Jesuit missionaries, resisted the pirates that threatened to invade the Visayan Islands to the north aided by the British and the Dutch. For historian Wenceslao E. Retana (18621924), the purpose of Fr. Francisco Combés's Historia de Mindanao y Joló (Madrid, 1667) was none other than to show their disagreement with the abandonment of southern Mindanao, arguing that the Spanish presence on Mindanao was fundamental (Retana, "Prologue," in Historia de Mindanao y Joló, ed. Francisco Combés [Madrid: Viuda de M. Minuesa de los Ríos, 1897 (1667)], ii-cxliii, here xviii).

195 Francis X. Hezel, The First Taint of Civilization: A History of the Caroline and Marshall Islands in Pre-colonial Days, 1521-1885 (Honolulu: University of Hawai'i Press, 1983), 42, 47-59.

196 According to the History of the Marianas (c.169o) by Luis de Morales, San Vitores himself "worked incessantly on the conversion of the Marianas with the purpose of sailing on to Japan to reestablish the faith; or continue on to the southernmost lands to make Jesus Christ known" (fol. 95).

197 Ines G. Županov, “Correnti e controcorrenti: La geopolitica gesuita in Asia (XVI secolo)," in I gesuiti ai tempi di Claudio Acquaviva: Strategie politiche, religiose e culturali tra Cinque e Seicento, ed. Paolo Broggio et al. (Brescia: Morcelliana, 2007), 205-18, here 205. 


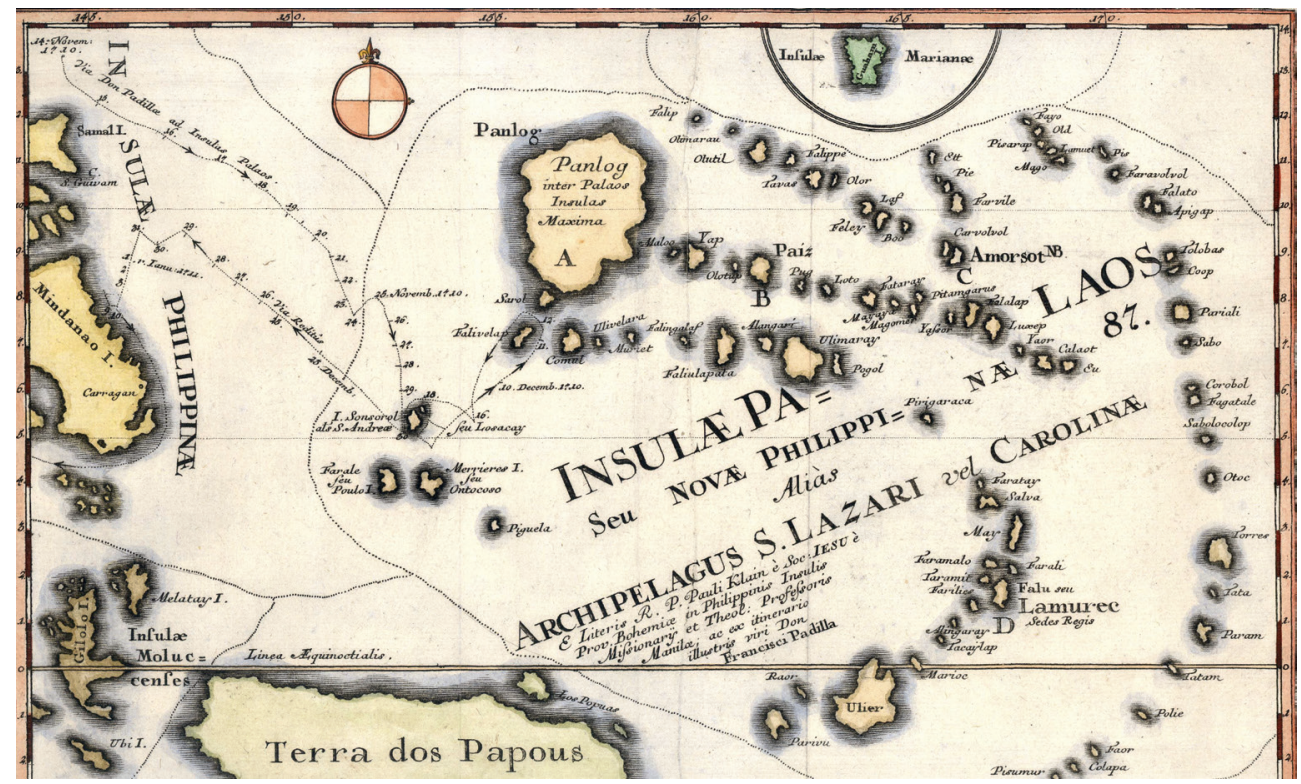

FIGURE 8 Map of Palaos and Caroline Islands

COURTESy OF THE MICRONESIAN AREA RESEARCH CENTER (MARC, GUAM)

or colonizing projects that they encouraged and that the authorities duly undertook, particularly after the Chamorro population in the Marianas had plummeted. The Society longed to explore or reconquer other frontiers in the Philippines, dreaming of finding the legendary Tarshish and Ophir of King Solomon.

On April 30, 1706, Pope Clement XI (r.1700-21) wrote to Philip v expressing his support for the Jesuits' evangelical project in the Palau islands, which had remained virtually isolated from all European contact. ${ }^{198}$ Two expeditions to the eastern seas beyond the Marianas were organized over the course of the next three years. The first, commanded by Pedro González de Pareja (dates unknown) and comprising three Jesuit priests-Antonio de Arias (1660-1733), José de Bobadilla (dates unknown), and Francisco Cabia (1672-1738), together with a lay brother, Francisco Aguarón $\left(1675^{-1737)}\right.$-was unable to reach its destination in 1708 due to insufficient supplies. ${ }^{199}$ The second expedition, from

198 On March 1, 1705, Pope Clement XI had already sent letters supporting the missions in the Philippines to his grandfather, Louis XIV of France (r.1643-1715), as well as to the archbishops of Mexico and Manila (Lévesque, History of Micronesia, 10:472-86). See also de la Costa, Jesuits in the Philippines, 550; 672; Hezel, First Taint of Civilization, 42-43.

199 Governor Zabalburu's letter to Philip v, Manila, July 4, 1709 (Lévesque, History of Micronesia, 10:573-74). See also Patricio Hidalgo Nuchera, ed., Redescubrimiento de las islas Palaos (Madrid: Miraguano \& Polifemo, 1993), 37-42. 
May to August 1709, led by General Miguel de Elorriaga (dates unknown), had more provisions than the earlier one, but the results were the same. Punished by typhoons, the four Jesuits on board the vessel Santísima Trinidad (Bobadilla, Felipe de Mesía [1699-1750], Pedro de Estrada [1680-1748], and Aguarón) returned to Manila without having reached their destination. ${ }^{200}$

These failures did not diminish the interest of the Philippine governors in the colonization of the Caroline Islands. On September 27, 1710, Governor Lizárraga sent the ship Santísima Trinidad with a crew of eighty-six men under the command of Sergeant Major Francisco de Padilla y Narváez (dates unknown), this time heading southeast. ${ }^{201}$ On board were three Jesuits: Jacques du Béron (in Spanish, Jacobo Dubéron) (1674-1710), the superior of the mission; Jacques Ferdinand Cortil $\left(1675^{-1710)},{ }^{202}\right.$ and Br. Etienne (or Esteban) Baudin (1673-1711), who hoped to begin the evangelization of the islanders. ${ }^{203}$ They left Cavite and arrived at Palapag (Leyte) on October 4, 1710. On the island of Samar, they were joined by the sloop San Miguel where Jesuits Serrano and Bobadilla were on board. The sloop was lost shortly thereafter in the shallow waters off Tubac, although the priests survived. ${ }^{204}$ The patache was more fortunate, and on November 30, it arrived at a coral atoll that was part of the Palau cluster, Sonsorol, which Dubéron then named San Andrés. ${ }^{205}$ The

200 Hidalgo Nuchera, Redescubrimiento de las islas Palaos, 43-101. See also Murillo Velarde, Historia de la provincia de Filipinas, fol. 378 ; Astrain, Historia de la Compañía de Jesús, 7:765-66; de la Costa, Jesuits in the Philippines, 550; and Gutiérrez, Historia de la iglesia en Filipinas, 263 .

201 Hidalgo Nuchera, Redescubrimiento de las islas Palaos, 10, 27-29; Francis X. Hezel, "Jesuit Martyrs in Micronesia," Micronesian Seminar, 1983, http://www.micsem.org/pubs/ articles/religion/frames/jesmartfr.htm (accessed February 13, 2018).

202 Fr. Cortil arrived in Guåhan in May or June of 1709. His stay was very brief, however, for in July 17 of the same year he wrote a letter from Luzon telling his relatives about the details of his journey from Acapulco to the Philippines (Lévesque, History of Micronesia, 11:69-74).

203 Murillo Velarde, Historia de la provincia de Filipinas, fol. $379^{\mathrm{r}}$. See also $\mathrm{M}^{\mathrm{a}}$ Lourdes DíazTrechuelo López Spínola, "Filipinas en el siglo de la Ilustración," in Historia general de Filipinas, ed. Leoncio Cabrero (Madrid: Ediciones de Cultura Hispánica, 2000), 249-92, here $273^{-74}$.

204 Sergeant Major Francisco de Padilla's letter to Philip v, Manila, July 11, 1712, in AG I, Filipinas 193, Ramo 6, no. 250, cited in Hidalgo Nuchera, Redescubrimiento de las islas Palaos, 35-36; "Relación escrita por el Francisco Calderón, Procurador General de la Provincia filipina de la Compañía de Jesús, sobre los sucesos de la expedición de Francisco de Padilla a las islas australes de los Palaos," in AG I, Filipinas 215, cited in Hidalgo Nuchera, Redescubrimiento de las islas Palaos, 130-31. See also Astrain, Historia de la Compañía de Jesús, 7:766; Juan José Delgado, Historia general sacroprofana, política y religiosa de las islas del Poniente llamadas Filipinas (Manila: El Eco de Filipinas, 1892 [1751]), 125.

205 "Carta o Memorial dirigido a su Majestad por el sargento mayor de Filipinas Don Francisco de Padilla, suplicando se le conceda un empleo en atención a los servicios que 
expedition's log, kept by Baudin and sent to Serrano from Lianga on January 18, 1711, contains ethnographic details about the natives of Sonsorol and Paloc as well as their fascination with iron. ${ }^{206}$ Like the Chamorros in the Marianas, the natives sailed over to the ships on their light boats and came on board to exchange coconuts, fish, rice, and water for iron tools. The first contacts took place on the beaches of Palau, which became liminal, in-between spaces where Spaniards and Carolinian natives were forced to communicate in what Australian historian Greg Dening (1931-2008) called "deep metaphors." 207 This exchange prefigured the coming transformations that European colonialism would soon bring to the Micronesian societies. ${ }^{208}$

In October 1711, one of the survivors of the previous expedition, Serrano, reunited the crème de la crème of the navigators from Manila and Cavite for the purpose of organizing a new expedition to the Palau islands. The interest the islands generated was strongly related to the survival of old myths regarding islands of gold protected by "monstrous races"-barbaric pagans, amazons - that had circulated during the eighteenth century. On October 15,

prestó como cabo de la gente de mar y guerra que se despachó a las islas de Palao para el descubrimiento de ella," Manila, July 14, 1712 (AHCJC, Documentos manuscritos acerca de la historia de las Filipinas, FiLPAs, no. 72, 1712-18, fols. $\left.90^{\mathrm{r}}-91^{\mathrm{v}}\right)$; Fr. Andrés Serrano's letter to the marquis de Mejorada y de la Breña, Manila, June 10, 1711, in Lévesque, History of Micronesia, 11:372-74. See also Hidalgo Nuchera, Redescubrimiento de las islas Palaos, 10.

206 "Relación en forma de diario, del descubrimiento de las islas Palaos, o Nuevas Filipinas," Lianga, January 18, 1711, in Cartas edificantes, y curiosas escritas de las misiones extranjeras, y de Levante, por algunos misioneros de la Compañía de Jesús, trans. Diego Davin (Madrid: Imprenta de la Viuda de Manuel Fernández, 1755), 7:fols. 243-44. Later, Francisco Calderón, procurator general of the Society of Jesus, wrote a "Relación sobre los sucesos de la expedición de Francisco de Padilla a las islas australes de los Palaos," which was first published by Francisco de la Barras de Aragón (1869-1955) ("Las islas Palaos," Anuario de estudios americanos 3 [1946]: 1081-89), and then by Hidalgo Nuchera (Redescubrimiento de las islas Palaos, 129-39). See also the letter that Cantova wrote to the provincial from the island of Dolores (in the Caroline Islands) on May 12, 1731 ("Descubrimiento y descripción de las islas de los Garbanzos [o Carolinas]," Boletín de la Sociedad Geográfica de Madrid 10 [1881]: 267 (this letter was also published in French in the Bulletin de la Société Académique Indo-Chinoise [July 1881]).

207 Greg Dening, Islands and Beaches (1980), cited in Carlos Mondragón Pérez-Grovas, "Reflexiones historiográficas en torno a las percepciones oceánicas durante los primeros encuentros entre europeos y melanesios en el Pacífico," in Un océano de intercambios: Hispanoasia (1521-1898). Un homenaje al profesor Leoncio Cabrero Fernández, ed. Miguel Luque Talaván and Marta M. Manchado López (Madrid: Agencia Española de Cooperación Internacional, 2008), 1:81-99, here 1:86-87.

208 As historian Nicholas Thomas observes: "The introduction of European material artefacts into tribal societies has generally been seen not just in negative terms but as emblematic of the disintegration of indigenous cultures in the face of imperial expansion" (Entangled Objects: Exchange, Material Culture, and Colonialism in the Pacific [Cambridge, MA: Harvard University Press, 1991], 2, 125-84). 
1711, the Santísima Trinidad set sail from Cavite heading toward the westernmost Caroline Islands, but three days later a strong storm wrecked the ship in the waters between Mindoro and Tayabas, close to the island of Marinduque, and all its passengers died, including the Jesuits Serrano, the superior and viceprovincial of the Palau mission Ignacio Crespo (1681-1711), and Baudin. ${ }^{209}$

In late 1711, the vessel Santo Domingo de Guzmán, which was to bring the situado to the Marianas, was ordered to sail toward the Palau islands, specifically San Andrés. Since he had taken possession in August 1709, the governor of the Marianas, Pimentel, had expressed his desire to discover the Garbanzo or Caroline Islands. ${ }^{210}$ On January 30, 1712, the first office or piloto mayor, Bernardino de Engoy y Zabalaga (also known as Bernardo de Egui [dates unknown]), left Guåhan, and a week later the ship reached the first islands of the archipelago. ${ }^{211}$ By February 2, they had discovered eighteen islands, of which Panlog was the largest, but the winds and sea currents kept them from continuing on to the islands of San Andrés. They finally returned to Cavite on March 15, taking two Palauans with them..$^{212}$

All of this, together with the tragic death of the three Jesuits, moved the civil and ecclesiastical authorities of Manila, many of whom thought that the Jesuits had been devoured by cannibals. On August 6, 1714, the procurator of the Jesuits in New Spain, Borja y Aragón, ${ }^{213}$ wrote a letter to the marquis of Mejorada from Mexico trying to persuade him not to abandon the islands. ${ }^{214}$ In this letter, he recommended that future expeditions to Palau leave directly

209 Fr. Pedro de Estrada's letter to Provincial Pedro de San Cristóbal, Manila, July 8, 1718 (RAH, Fondos Cortes, 567, 9-2675/11, fol. $\mathrm{1}^{\mathrm{r}}$ ). See also Delgado, Historia general sacroprofana, 127; Hezel, First Taint of Civilization, 44-45; Hidalgo Nuchera, Redescubrimiento de las islas Palaos, 11 .

210 AG I, Filipinas, 129, Ex 101. See also the letter that Governor Pimentel wrote to Philip v from Humåtac on January 23, 1712 (Lévesque, History of Micronesia, 11:541-43).

211 "Testimonio de autos dado en Manila sobre lo ejecutado en el presente año [1712] en el descubrimiento y reducción de las islas de Pais o Palaos" (AHCJC, Documentos manuscritos acerca de la historia de las Filipinas, FILPAS, no. 72, 1712-18, fol. $25^{\mathrm{r}}$ ). The travel journal, written by Bernardino de Engoy (also known as Bernardo de Egui), Cavite, April 14, 1712, is transcribed in fols. $16^{\mathrm{v}}-37^{\mathrm{v}}$, and a copy is published in Lévesque, History of Micronesia, 11:490-96.

212 "El viaje de Bernardino de Engoy y Zabalaga (1712)," cited in Hidalgo Nuchera, Redescubrimiento de las islas Palaos, 201-15. See also Delgado, Historia general sacroprofa$n a, 127-28$.

213 Francisco de Borja y Aragón was also the apoderado (representative) of the sergeant major of the Marianas' presidio, José de Quiroga y Losada (Lévesque, History of Micronesia, 11:442).

214 Procurador Francisco de Borja y Aragón's letter to the marquis de Mejorada, Mexico, August 6, 1714 (AHCJC, Documentos manuscritos acerca de la historia de las Filipinas, FILPAS, no. $72,1712-18$, fols. $141^{\mathrm{r}}-143^{\mathrm{v}}$ ). See also Lévesque, History of Micronesia, 11:623-26. 
from Guåhan. ${ }^{215}$ On February 15, 1715, the Council of the Indies consulted the monarch about the instructions regarding the exploration of the westernmost Caroline Islands. ${ }^{216}$ The expenses that these expeditions entailed for the royal treasury could be significant, and the governors of the Philippines and the Marianas were ordered not to embark upon new expeditions without first consulting the council. ${ }^{217}$

As a result of the conversations and petitions, Philip v sent a royal decree to the governor and captain general of the Philippines on November 11, 1715, confirming the designation of the first officer and ordering that the patache to the Marianas be supplied with firearms, gunpowder, and ammunition, as well as tools, nails, and everything necessary for ship-building. ${ }^{218}$ Governor Pimentel received orders to send a patache with twenty-five of the sixty Spanish soldiers in the presidio under the orders of a corporal or cabo and two Jesuit priests to conquer and evangelize Palau. ${ }^{219}$

Economic disinterest, as well as the islanders' reputation for cannibalism, had dissuaded potential investors from participating in the exploration of the "new Philippines." The Jesuits, however, saw the evangelization of the islanders as an opportunity to win new souls for Catholicism. In Bonani's words, "Oh, how I wish so willingly to go to that mission [of the Palau] with my sickle and transfer my parish to another one all new."220

At this point, Catholic "providential utopianism" was thought of as a way to contradict the mainstream cultural forces producing miserable conditions for

215 He recommended using the patache that periodically brought first aid supplies to the Marianas from the Philippines to take men and merchandise to the mission in Palau (AHCJC, Documentos manuscritos acerca de la historia de las Filipinas, FILPAS, no. 72, 1712-18, fols. $142^{\mathrm{v}}-143^{\mathrm{v}}$ ). See also Lévesque, History of Micronesia, 11:625-26.

216 "Consulta del Consejo de Indias a su Majestad sobre las órdenes que deben darse en el descubrimiento de las islas Palaos en Filipinas, February 15, 1715" (AHCJC, Documentos manuscritos acerca de la historia de las Filipinas, FILPAS, no. $72,1712-18$, fols. $147^{\mathrm{r}}-148^{\mathrm{v}}$ ).

217 AGI, Filipinas 333, bundle 12, fols. $149^{\mathrm{r}}-149^{\mathrm{v}}$.

218 Royal decree for the governor of the Philippines, Buen Retiro, November 11, 1715 (AHCJC, Documentos manuscritos acerca de la historia de las Filipinas, FILPAS, no. 72, 1712-18, fols. $23^{1}-233^{r}$ ). There is a copy of this decree in Lévesque, History of Micronesia, 12:38-40.

219 AHCJC, Documentos manuscritos acerca de la historia de las Filipinas, FILPAS, no. 72, 171218, fols. $234^{\mathrm{r}}-23^{\mathrm{v}}$. On June 13, 1717, Governor Pimentel replied to the Philippine governor that he could not satisfy his wishes due to the lack of capable military personnel in the Marianas as well as missionaries, for the latter (six priests) were very old and were needed to tend to the souls of the inhabitants (AGI Ultramar, bundle 13, cited in Lévesque, History of the Marianas, 12:71-72).

220 Fr. Joseph Bonani's letter to Fr. Sigismondo Pusch, November 26, 1720 (AHCJC, FILCAR E.I, a-18. 1677-1750, part 1: 1677-1735, E.I. a-18/1, fol. $\left.122^{\mathrm{v}}\right)$. 
the majority of the native population living on the fringes of Spanish America. If utopias offer an unfinished dream with which to provide for justice and wellbeing, the religious - social ideals behind Jesuit Bonani's thinking is evident. ${ }^{221}$ His desires were revived when a boat with eleven men, seven women, and six children arrived in the Marianas. They came from the islands of Ulle and Falalop (Faraulep, Yap State) in the Caroline archipelago and ended up disembarking close to the town of Inarajan (or Inalåhan) on June 6, 1721. Two days later, four men, one woman, and one child disembarked off another vessel at the peak of Orote. They meant to reach Ulithi, but a violent storm had thrown them off course and they had been adrift for nearly twenty days. ${ }^{22}$ The mayor of the partido of Agat (or Hagat) initially thought that the boat was an enemy frigate, as only a month earlier the presidio soldiers had repelled English corsair John Clipperton off the port of Merizo, capturing two of his officers. ${ }^{223}$

Fascinated by what he believed to be an act of divine providence, one of the Jesuits destined for the Mariana Islands, Cantova, expressed his desire that the Marianas become "the door through which to enter a great number of southern islands, entirely unknown."224 The bad example set by the Spaniards, particularly Governor Pimentel, ${ }^{225}$ had made him reflect on the need to moderate the harsh reality of the Marianas. And he was not mistaken. On May 23, 1719, Cantova wrote a letter to the Jesuit superior general in which he shared his

221 Ernst Bloch, cited in Salvador Bernabéu Albert, "Las utopías y el reformismo borbónico," in El reformismo borbónico, ed. Agustín Guimerá (Madrid: Alianza Universidad, 1996), 247-64, here 250-51. Regarding utopian thought in the Jesuit missions, see Girolamo Imbruglia, L'invenzione del Paraguay (Naples: Bibliopolis, 1983); Imbruglia, "Peculiar Idea of Empire," 39-42. For a broader analysis of utopian thought throughout colonial Latin America, see Beatriz Pastor, El jardín y el peregrino: El pensamiento utópico en América Latina (1492-1695) (México, DF: Universidad Nacional Autónoma de México, 1999).

222 Letter from Sánchez de Tagle, governor of the Marianas, to King Philip v, "En la que le da cuenta de la llegada a Guam de dos grupos de carolinos en dos embarcaciones," Agaña, June 21, 1721 (AGI, Ultramar 561, fols. $65^{\mathrm{r}}-66^{\mathrm{r}}$ ). See also Hezel, First Taint of Civilization, 48.

223 Hezel, From Conquest to Colonization, 57-58; Driver, Spanish Governors, 22.

224 Fr. Juan Antonio Cantova's letter to Fr. Guillermo Daubenton, fol. 193, in Cartas edificantes, y curiosas escritas de las misiones extranjeras, $y$ de Levante, por algunos misioneros de la Compañía de Jesús, trans. Diego Davin, vol. 11 (Madrid: Imprenta de la Viuda de Manuel Fernández, 1756).

225 Driver, El Palacio, 16-18; Driver, "Notes and Documents"; Hezel, From Conquest to Colonization, 40-49; Francisco Borja de Medina, "El Real Colegio-Seminario de San Juan de Letrán de las islas Marianas: El sueño del Beato Diego Luis de Sanvitores, S.J., y su realidad cotidiana (1669-1768)"; Conference in XII Misiones Jesuíticas. Jornadas Internacionales, Interacciones y sentidos de la conversión, September 26, 2008, Buenos Aires, Argentina. 
impressions about the moral and material state of the Marianas archipelago: isolation, misery, and poverty were widespread. The islands had nearly 4,500 inhabitants, counting Spaniards and natives, most of whom were practically dressed in rags. ${ }^{226}$ That same year, he wrote to the calificatores of the Holy Office that he had absolved five penitents who had invoked the devil. 227

In 1719, Cantova was involved in a dispute with Pimentel over the forced labor the natives were subjected to, planting foodstuffs — rice, corn, melons, and the like- that the governor then sold at exorbitant prices to the galleons and pataches that came looking for provisions. To put an end to this injustice, Sergeant Major Quiroga y Losada wrote to the king on May 26, 1720 denouncing the exploitation. ${ }^{228}$ Cantova, then rector of the San Juan de Letrán school, knew of Quiroga y Losada's opinions regarding these abuses. He himself had tried to correct them, unsuccessfully. Given his good relations with the Society of Jesus, it is no surprise that Quiroga y Losada became their spokesperson in denouncing the despotism of the governor to the monarch. ${ }^{229}$ Cantova also publicly denounced the governor in his sermons, criticizing his bad habits. The governor, on the other hand, accused him and Vice-Provincial Ignacio de Ibargüen (in office $1712-30)^{230}$ of sedition and exiled them to Humåtac, where they could not bother him with their condemnations. ${ }^{231}$

226 ARSI, "Lettera del V. Cantova," San Ignacio de Agaña, May 23, 1719, vol. 13, Philippinae historiae, $1663^{-1734}$, fols. $349^{\mathrm{r}}-349^{\mathrm{v}}$.

227 Archivo General de la Nación, México (henceforth, AGN), Inquisición, vol. 552, Ex 16, fol. 75, cited in James B. Tueller, "Los chamorros de Guam y la colonización española: Una tercera etapa (1698-1747)," in Imperios y naciones en el Pacífico, vol. 2, Colonialismo e identidad nacional en Filipinas y Micronesia, ed. $\mathrm{M}^{\mathrm{a}}$ Dolores Elizalde, Josep $\mathrm{M}^{\mathrm{a}}$ Fradera, and Luis Alonso (Madrid: CSIC, 2001), 385-94, here 389-9o.

228 Driver, "Notes and Documents," 98-106.

229 On June 8, 1719, Sergeant Major Quiroga wrote a letter to the Council of the Indies denouncing the arbitrary actions of Governor Pimentel, particularly regarding the exile of Ignacio de Ibargüen and Cantova, accused of being "rebellious, unruly, and imprudent" (revoltosos, inquietos e imprudentes) (AGI, Filipinas 95, fols. $1^{\mathrm{v}}-2^{\mathrm{r}}$ ).

230 In 1717, Bustillo recommended Ibargüen as his replacement for the position of commissar of the Holy Office. The second in line was Cantova, followed by Muscati. But because of the colonizing campaigns of the Jesuits on the Caroline Islands, Inquisitors Joseph de Cienfuegos, Francisco Antonio de Palacio y del Hoyo, and Francisco de Garzarón wrote to Ignacio de Ibargüen on February 22, 1721 asking him to replace Cantova as his primary substitute "if he does not return to [the Marianas] shortly" (AGN, Inquisición, 65o:file 2, fols. $329^{r-v}$ ). Ibargüen was a pious man who in 1721 wrote a prayer book to honor Saint Bridget (AGN, Inquisición, 759:exp. Sin número, fols. $496^{\mathrm{r}}-497^{\mathrm{r}}, 500^{\mathrm{r}}$ ).

231 Fulcherio di Spilimbergo, Breve relación de la vida, virtudes y gloriosa muerte (c.1740), fol. 304. The governor meant to have them exiled to Castile, but no patache or galleon came to the islands that year, so they both remained in the Marianas. See Quiroga's letter to King Philip v, June 8, 1720 (AGI, Ultramar 561), cited in Hezel, From Conquest to Colonization, 
Unsurprisingly, the Jesuits' discontent with the lascivious and corrupt behavior of the colonial officials grew. They thought that the Chamorros had been corrupted by the officials' bad example, and that God's punishment had been to extinguish their population. In the summer of 1720, the San Andrés, captained by Bernardino de Engoy, brought the new governor Sánchez de Tagle, who showed himself favorable to exploring the Caroline Islands. ${ }^{232}$ On June 19, 1721, twenty-four drift voyagers, men, women, and children from Woleai, arrived in Guåhan in a canoe not very different from the Chamorro swift proas, according to Cantova. ${ }^{233}$ Cantova baptized several children while allowing their parents to leave Guam because it was "morally impossible for them, without pastors in the midst of a pagan people, not to revert to their original heathenism." 234

Two days later, six more starving castaways arrived at Orote (or Urotte) Point. That same day, on June 21, Sánchez de Tagle wrote a letter to Philip v, asking for a yearly allotment of forty thousand pesos to finance the expedition. ${ }^{235}$ Cantova, however, mistrusted the intentions of the new governor, whose indiscriminate use of native forced labor was no different from that of his predecessors. ${ }^{236}$ Disappointed with the governor's behavior, in 1722 the Jesuit priest wrote to the visitador (representative) Juan Antonio de Oviedo (1670-1757) asking him for a license to accompany the Caroline natives back to their home islands in order to learn about their character and customs and proceed with their evangelization. ${ }^{237}$ If there was a "garden" where Jesuits could harvest new

49; Lévesque, History of Micronesia, 12:159-161; Quiroga's letter to King Philip v, May 26, 1720 (AGI, Ultramar 561), cited in Driver, "Notes and Documents," 105-6. In 1724, during the government of Sánchez de Tagle (in office 1720-25), an aging and ailing Sergeant Major Quiroga was replaced by Captain Manuel Díaz de Dozal. See Driver, El Palacio, 19; also, Driver, Spanish Governors, 22.

232 Driver, El Palacio, 18-19; Driver, Spanish Governors, 22; Xavier Baró i Queralt, Misioneros en el Pacífico: Los intentos de evangelización de las islas Marianas y Palaos (1710-1733) (Girona: Documenta Universitaria, 2013), 53.

233 Hezel, First Taint of Civilization, 48-49.

234 Hezel, First Taint of Civilization, 49.

235 On January 23, 1723, the prosecutor of the Council of the Indies denied Governor Sánchez de Tagle's request to organize the expedition, arguing that "it does not seem conducive now, until it is known what the people referred to have come for, because, not understanding their language, we cannot know whether the reduction of the Carolinas Islands is at all possible, for we do not know whether these people are native to those islands or are from elsewhere" (AHCJC, Documentos manuscritos acerca de la historia de las Filipinas, FILPAS, no. $77,1720-21$, fol. $\left.75^{\mathrm{v}}\right)$.

236 Hezel, From Conquest to Colonization, 49.

237 Cantova's letter to Guillermo Daubenton, fol. 199. See also Hezel, First Taint of Civilization, 49-50. 
"spiritual flowers" and offer them to the Lord, Cantova was certain that it was not in the Marianas, but in the new spiritual frontier of the Caroline Islands. ${ }^{238}$ Since the reply he received was not enthusiastic, he moved to Inarahan (or Inalåhan) with Vice-Provincial Muscati. ${ }^{239}$ He wanted to convince his superior personally about the existence of a "new archipelago" where political and religious life could be fused harmoniously. ${ }^{240}$

Historian Francis X. Hezel has remarked that the 1722 letter sent by Cantova to French Jesuit Guillaume Daubenton (1648-1723) is an ethnographic exercise tout court. It was an almost journalistic report, detailing the forms of political organization, customs, and religion of the Carolinians during their four-month stay on Guåhan. ${ }^{241}$ The letter begins by highlighting two fundamental aspects that justified the expedition: first of all, the good disposition of the Caroline guests who exchanged bracelets and pieces of coral with the Spanish, suggesting that commercial relations could be quickly established; ${ }^{242}$ and second, their supposed intellectual superiority, which despite their barbaric ways and pagan beliefs, made Cantova think of them as having the status of naturally moral creatures. ${ }^{243}$

238 Cañizares-Esguerra, Puritan Conquistadors, 179-86.

239 There is some doubt surrounding the exact date of Vice-Provincial Muscati's death. Based on the information gathered by Fr. Murillo Velarde in his Historia, Jesuit Antonio Astrain states that he died in 1716 at the age of seventy-four, having worked in the Marianas for nearly forty-eight years (Historia de la Compañia de Jesús, 7:762). Hezel, however, identifies 1739 as the year of his death (From Conquest to Colonization, 9o). In any case, there is consensus regarding the benefits of his administration, under which the missions of the Marianas attained some stability (Santiago Lorenzo García, La expulsión de los jesuitas de Filipinas [Alicante: Universidad de Alicante, 1999], 55).

240 In 1702, Lorenzo Bustillo complained that the governors of the Marianas had paid no attention to the discovery of the islands to the south in 1686 , arguing that they were more concerned about their personal enterprises than about the salvation of the natives' souls (“Reparos sobre el arbitrio y lo imposible de su ejecución," April 10, 1702 [ARSI, vol. 13. Litterae annuae Philipp, 1663-1734 [etiam de Insulis Marianis], fol. $329^{\mathrm{r}}$ ).

241 Francis X. Hezel and María Teresa del Valle, "Early European Contacts with the Western Carolines: 1525-1750," Journal of Pacific History 7, no. 1 (1972): 26-44, here 41-44.

242 The docility and domesticity of the majority of the Palau natives had already been described by Br. Baudin in his diary, which suggests that commercial relations had already been established with the Marianas' inhabitants ("Relación escrita por el Francisco Calderón, Procurador General de la Provincia filipina de la Compañía de Jesús, sobre los sucesos de la expedición de Francisco de Padilla a las islas australes de los Palaos," in AGI, Filipinas 215, cited in Hidalgo Nuchera, Redescubrimiento de las islas Palaos, 138-39). See Thompson, "Native Culture of the Mariana Islands," 41.

243 Cantova's letter to Daubenton, fol. 211. See also the 1732 "Relación de las islas Carolinas y Palaos sacada de una memoria escrita del V. Juan Cantova, misionero de las Marianas y 
On June 30, 1727, Cosío y Campo, marquise of Torre-Campo, confirmed to the monarch what Cantova and Governor Manuel de Argüelles had warned: that, indeed, the number of inhabitants of the Marianas, including the soldiers in the presidio, was below three thousand. ${ }^{244}$ After a consultation carried out by the Audience of Manila on July 3, 1727, Cantova recommended the reduction of the presidio force to twenty-five soldiers under the command of a superior corporal with the civil and criminal authority of a first instance court judge. He also decided that the number of Jesuit missionaries be reduced to three, with a (lay) temporal coadjutor brother, with the same stipend that they had been receiving previously for their support. ${ }^{245}$

In the meantime, new boats of Caroline Indians arrived periodically on the Philippine coasts, and the Jesuits interpreted this as a providential sign that God had sent them to finally embark upon the new enterprise. With the hope that part of the men stationed in the Marianas would be sent to the Carolines, Cantova insisted on the organization of an expedition that would bring Christ's message of liberation (Christum ferens) to the natives. ${ }^{246}$ In 1728 , Provincial Pedro de la Hera (in office $1726-30$ ) asked the Philippines' governor, Fernando Valdés y Tamón (in office $1729-39$ ), to organize the expedition. ${ }^{247}$ To accomplish this goal, the governor gathered a governing body to decree the exploration of the Garbanzo Islands, starting with the closest island, Carolina. According to some reports, their inhabitants were peaceful, while those of Palau were cannibalistic warriors. The governor thus considered it unnecessary to send a military escort on this first expedition, and he instead ordered the Marianas' governor to send a group of fourteen Pampangos, Chamorros, or mestizos who could handle firearms, as well as a few carpenters who could help build the first church or house. ${ }^{248}$

Palaos, mártir de la fe en estas últimas" (AHCJC, FILCAR E.I, a-18. 1677-1750, part 2, 1732 a 1750. E.I. a-18/2, fols. $367-72$ ).

244 Marquise de Torrecampo's letter to the king, Manila, June 30, 1727 (AG I, Ultramar 561 [2], N.2, leg. 20, fol. $74^{\mathrm{r}}-74^{\mathrm{v}}$; AG I, Filipinas 141, N. 22. See also Lévesque, History of Micronesia, 13:17-45).

245 AGI, Filipinas 144, N. 22.

246 Cañizares-Esguerra, Puritan Conquistadors, 51.

247 Baró i Queralt, Misioneros en el Pacífico, 55; Xavier Baró i Queralt, "La primera mundialización y la mirada sobre el otro: Las misiones jesuíticas en ultramar," in A vueltas con el pasado: Historia, memoria y vida, ed. Joan-Lluís Palos and Fernando Sánchez-Costa (Barcelona: Publicacions de l'Universitat de Barcelona, 2013), 129-51, here 144.

248 "Testimonio legalizado de los autos hechos a pedimento del padre Pedro de la Hera, de la Compañía de Jesús, sobre el descubrimiento de las islas Palaos" (1728), cited in Lévesque, History of Micronesia, 13:112-15; Astrain, Historia de la Compañía de Jesús, 7:773-74. There were 130 soldiers assigned to the Marianas' royal presidio at that time. The 1727 situado of 
Determined to find - or found - the ideal society, Cantova embarked on the vessel Nuestra Señora de los Dolores headed toward the Marianas in 1729, but after three months, contrary winds and the lack of food supplies forced its first officer to return to the Philippines. Bad luck did not weaken Cantova's zeal, however, and under the protection of the Virgin of Loreto, whom he designated the ship's patron, he arrived at the port of Merizo (or Malesso') on October $28,1730 .{ }^{249}$ Bonani harbored great desires to accompany him on his journey. As he himself wrote to Fr. Giovanni Ulrich (or Udalrico) Bombardi (1691-1774): "I suffered a disillusion: he had been granted permission to take a companion who would be selected by the superior. How I struggled, how I ardently begged to be that companion! But another was chosen, from Brixen, Tyrol: Victor Walter of the upper German province."250

The Philippine Jesuits' interest in colonizing the new islands of the Pacific lay in the desire to win greater influence and ecclesiastical power. The Marianas mission was in an evident state of decay, and many missionaries were looking for other spiritual gardens where they could gather more fruit. One possibility was to colonize the Muslim islands located in the southern Philippines. At the beginning of 1730 , a fleet of twenty ships with three thousand pirates from Sulu attacked the southernmost islands of the Philippine archipelago. Governor Valdés y Tamón ordered one of his most experienced men, Francisco de Cárdenas Pacheco (dates unknown), to man a fleet against Prince Malinog (d.1748), son of Bayan ul-Anwār, and his Muslim allies in reprisal for the assassination of the sultan of Maguindanao, a Spanish ally. ${ }^{251}$ And again in 1733, it

48,393 pesos scarcely covered the salaries of the governor, the sergeant major, and sixty soldiers (Lévesque, History of Micronesia, 12:677-78). Captain Nicolás Guerrero and Jesuit Ignacio de Ibargüen requested that the 1728 situado bring the wages of 134 soldiers to compensate for the previous year's deficiency, arguing moreover that they had had to increase the number of soldiers due to the conquest and colonization of the Carolinas (AGN, Instituciones coloniales, Indiferente Virreinal, boxes 1-999, box 0599, file 023 [Cárceles y Presidios], fols. $1^{\mathrm{r}}-2^{\mathrm{v}}$ ).

249 Cantova's letter to Fr. Murillo Velarde, Agaña, January 10, 1731, in Murillo Velarde, Historia de la provincia de Filipinas, fol. $382^{\mathrm{r}}$. See also Antonio Egea López, "Las islas Marianas, provincia Española: Una introducción a su estudio," in España y el Pacífico, ed. Florentino Rodao (Madrid: AECI \& AEEP, 1989), 153-67, here 16o. The preparations for the trip to the Marianas are described in AGI, Filipinas 415 , fols. $1^{\mathrm{r}}-20^{\mathrm{v}}$.

250 Fr. Joseph Bonani's letter to Fr. Ulrico (or Michael) Bombardi, Guåhan, May 20, 1733 (AHCJC, FILCAR E.I, a-18, 1677-1750, part 2, 1732-50. E.I. a-18/1, fol. 211). English and German translations of this letter are available in Lévesque, History of Micronesia, 13:268-73.

251 In 1722, he had already recruited, by his account, a company of fifty men and three ships to punish the activities of the "Moorish" pirates (Relación de servicios, Sergeant Major Francisco de Cárdenas Pacheco; AGI, Filipinas 118, N. 9). 
was up to General Cárdenas, then governor of the presidio of Zamboanga, to traverse the coasts of Mindanao and Sulu and intimidate the pirates. ${ }^{252}$

The other objective was to promote the conquest and evangelization of the "new Philippines." As Hezel observed: "It was not until 1731, ten years after he had first met the Carolinians on Guam, that Cantova was able to obtain permission from his superiors to make another attempt to reach their islands." ${ }^{253}$ Indeed, on February 11, 1731, both priests, accompanied by twelve soldiers and eight cabin boys, set sail from the port of Humåtac headed toward the Caroline Islands. ${ }^{254}$ They visited various islands before reaching Mogmog (presentday Ulithi), where the tamol or chief Indian lived, and then continued on to Falalop, the largest islet of Ulithi, also called the Garbanzos Islands or Dolores Islands, some eighty leagues southeast of the Marianas. ${ }^{255}$ From the beginning, the priests dedicated themselves to baptizing 150 dying children, catechizing the adults, and planting crosses on the eight islands they visited in an attempt to exorcize the forces of evil. They brought with them an image of Our Lady of Loreto, the symbol of Christian life, to invoke her protection from storms and help them free the natives from the devil's deceptions. For a few years, the hymn of Loreto was sung during Saturday Mass in the Marianas, morning and night, with gun salutes. ${ }^{256}$ Her cult was related to a miraculous sculpture of the Virgin attributed to Saint Luke, who after a short stay on the coasts of Dalmatia had apparently been lodged in the house where the Virgin had lived, the same house where Jesus had spent his childhood. It was a devotion common to all Jesuits that reinforced the family ties that the Society maintained with Europe. ${ }^{257}$

252 On April 18, 1731, General Cárdenas Pacheco was named governor of the Marianas; he took possession on August 25, 1734 (AGI, Filipinas 118, N. 9). See Relación de servicios, "Don Francisco de Cárdenas Pacheco, Governor and Captain General of the Mariana Islands" (AGI, Indiferente, 146, N. 99, fols. $1^{\text {r}}-4^{\text {r }}$; AGI, Ultramar 561 [2], leg. 16, N. 3, fol. 9).

253 Hezel, First Taint of Civilization, 50.

254 Cantova's letter to Fr. Pedro de la Hera, Falalop, May 27, $173^{1}$ (Lévesque, History of Micronesia, 13:193-98); Spilimbergo, "Breve relación de la vida, y virtudes del V. Juan Antonio Cantova," cited in Lévesque, History of Micronesia, 13:311, 314; Delgado, Historia general sacroprofana, 128. See also Baró i Queralt, Misioneros en el Pacífico, 56.

255 Hezel, First Taint of Civilization, 45.

256 Fr. Juan Antonio Cantova's letter to Fr. Ulrico Bombardi, Guåhan, May 20, 1733 (AHCJC, FILCAR E.I, a-18. 1677-1750, part 2, 1732-50, E.I. a-18/1, fol. 210).

257 Luisa Elena Alcalá, Fundaciones jesuíticas en Iberoamérica (Madrid: Fundación Iberdrola, 2002), 50; Pilar Gonzalbo Aizpuru, "Las devociones marianas en la vieja provincia de la Compañía de Jesús," in Manifestaciones religiosas en el mundo colonial americano, vol. 2, Mujeres, instituciones y culto a María, ed. Clara García Ayluardo and Manuel Ramos Medina [Mexico: INAH, Universidad Iberoamericana, and Condumex, 1997], 257-81, here 262-64). 
Cantova sought to gain the natives' trust by using the tried-and-true Loreto devotion, hoping that they would break with their pagan past and build a new church in the Caroline Islands under the authority of the pope. It was no coincidence that the small chapel built in Falalop was named after the Virgin of Loreto. ${ }^{258}$

Unlike the idols in the form of crocodiles adored by the natives, the image of the Virgin was not an object of worship in itself, but an instrument meant to remind them of Mary's permanent presence. Indeed, with great satisfaction, Cantova wrote: "These natives do not tire of coming and admiring the beauty of this Divine Lady and her holy son; and they say, that they cannot but believe in God, for they can see him with their eyes, and they see their mother."259 The letters he wrote to the governor of the Philippines and the provincial Pedro de la Hera from Falalop on May 12 and 27,1731 revealed that the missionaries were cordially received, but their methods of control-baptisms, concentrating the population, censuses-began to generate mistrust among the islanders. One Chamorro refugee sowed the seeds of suspicion. He accused the Spanish of waging war on the Chamorros and imposing onerous labor conditions. ${ }^{260}$ At the last moment, and to prevent greater evils, Cantova decided to send Fr. Walter back to Guåhan to secure needed supplies for the Ulithi mission on May 31, 1731. However, the ship he was traveling on changed its course to Manila in July 1731. There, he delivered Cantova's letters to the civil and ecclesiastical authorities, along with a map of Ulithi, with a considerable lack of support and enthusiasm on the part of Governor Valdés y Tamón. ${ }^{261}$ Cantova was supposed to have gathered basic information about the number, customs, and traditions of the inhabitants and the land. After all, the future mission depended on the number of Ulithians as well as the type and quantity of sufficient resources available to support the missionaries.

In the meantime, news had been sent about the missionaries' imminent arrival in the Marianas. On August 11, 1731, Bonani read the letters describing the

258 Spilimbergo, "Breve relación de la vida, y virtudes del V. Juan Antonio Cantova," cited in Lévesque, History of Micronesia, 13:312.

259 "Descubrimiento y descripción de las islas de los Garbanzos (o Carolinas)," Boletín de la Sociedad Geográfica de Madrid 10 (1881): 263-79, here 265.

26o Cantova's letter to Provincial Pedro de la Hera, May 27, 1731, cited in Lévesque, History of Micronesia, 13:197; "Descubrimiento y descripción de las islas de los Garbanzos (o Carolinas)," 269. See also Astrain, Historia de la Compañía de Jesús, 7:774-75.

261 Baró i Queralt, Misioneros en las Filipinas, 56-57; Baró i Queralt, "La primera mundialización y la mirada sobre el otro," 145 . 


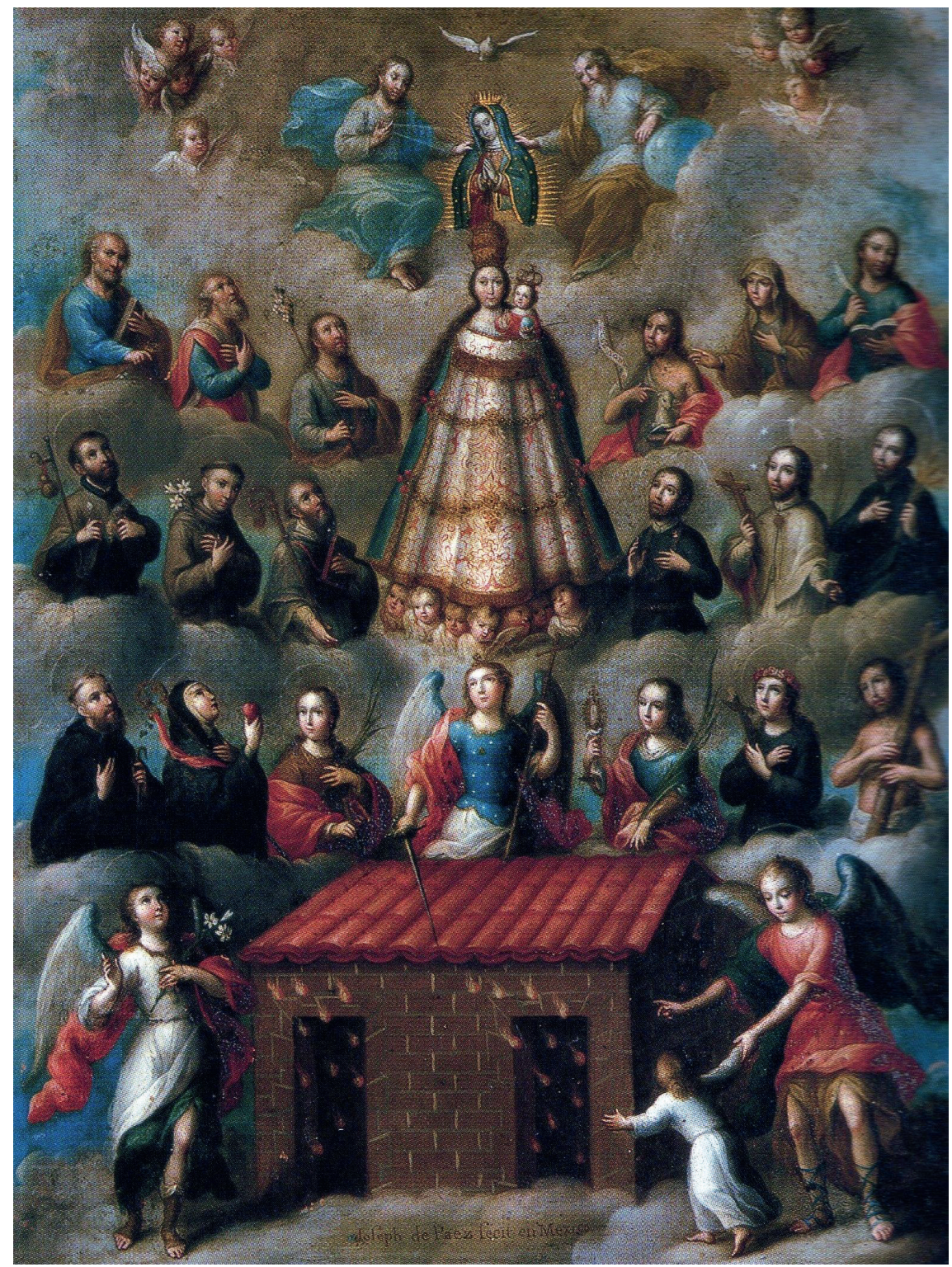

Figure 9 José Páez, "Virgen de Loreto con su casa, coro de santos y el alma de la Virgen como la Virgen de Guadalupe (1770)." Museo de America, Madrid 
progress of the missions in the Caroline Islands. ${ }^{262}$ In June 1731, Walter headed to the Marianas to obtain additional supplies and more manpower for the fledging mission. ${ }^{263}$ On November 12, 1731, he arrived along with some other priests and a small battalion of forty soldiers. ${ }^{264}$ However, because of the repairs that had to be carried out on his ship, Walter was unable to set sail for the Caroline Islands until November 12, 1732. After three and a half months at sea, the patache spotted the coasts of Guam but shipwrecked in the port of Merizo, losing "the greater part of the food supplies." ${ }^{265}$ It took the Jesuits nearly six months to build another patache. In late March 1733, Walter, Brother Lewin (or Levino) Schrebel (d.1733), and forty-four other passengers - of whom twelve were soldiers-finally embarked toward the Caroline isles. ${ }^{266}$ After nine days at sea, they reached the island of Falalop on July 2, where they found the charred remains of the town. Most of the elusive Indians had moved away, but some responded that Cantova had moved to the island of Yap. The party went in search of the priest, taking one of the natives with them by force. Unable to find the island, they returned to Manila, where they learned that the Jesuit priest and Spanish troops had been massacred by the natives soon after Walter's departure in June 1731. The captured Carolinean told them that Cantova, along with his catechist and translator, and two soldiers, had gone to the island of Mogmog with the intention of baptizing a dying adult. ${ }^{267}$ When they landed, however, the inhabitants had surrounded them, armed and threatening, and the Jesuit had questioned their attitude, saying:

Is it possible that you want to take my life? What evil have I done you? I come preaching eternal truths and placing you on the road to salvation. Could I do you a greater good? You come, they answered, to destroy our customs and our mores: we do not want to be Christian; and without

\footnotetext{
262 Cantova's letter to Bombardi, Guåhan, May 20, 1733 (AHCJC, FILCAR E.I, a-18. 1677-1750, part 2, 1732-50, E.I. a-18/1, fols. 211-12).

263 Hezel, "Jesuit Martyrs in Micronesia."

264 Baró i Queralt, Misioneros en las Filipinas, 57.

265 Cantova's letter to Bombardi, Guåhan, May 20, 1733 (AHCJC, FILCAR E.I, a-18, 1677-1750, part 2, 1732-50, E.I. a-18/1, fol. 211).

266 Spilimbergo, "Breve relación de la vida, y virtudes del V. Juan Antonio Cantova," cited in Lévesque, History of Micronesia, 13:319. See also "Carta a los RR. Jesuitas" (n.d.), in Cartas edificantes, y curiosas escritas de las misiones extranjeras, 13:fol. viii. See also Murillo Velarde, Historia de la provincia de Filipinas, fol. $381^{\mathrm{r}}$; Astrain, Historia de la Compañía de Jesús, 7:779; Hezel, First Taint of Civilization, 58.

267 Delgado, Historia general sacroprofana, 128-29.
} 
another word, they attacked him thrice with a lance, once through his heart, and twice on his side. ${ }^{268}$

Endowed with the power of speech, the missionaries' role as participant observers is highlighted, as is the dialogic position from which their views on the apparent neglect of the evangelizing project on the part of the civil authorities is best understood. In his Relectio de Indis (Lectures on the American Indians [1539]), Francisco de Vitoria (1483-1546) had argued that the Spanish could not force the New World Indians to believe in Christianity or take their land. Violence was justified only if the missionaries were attacked. Jesuits were often accompanied by Pampangan or Visayan soldiers from the Philippines to defend them if attempts were made on their lives by natives reluctant to accept Christianity. But this was often interpreted by the "savages" who adored "false" gods - superstiti-at the confines of the known world as a declaration of war.

In any case, after Cantova was waylaid by a hostile group of Ulithians, the Breve relación de la vida, virtudes y gloriosa muerte del V.P.Juan Antonio Cantova, de la Compañía de Jesús, muerto a manos de los bárbaros carolinos (Brief report about the life, virtues, and glorious death of Venerable Father Juan Antonio Cantova of the Society of Jesus, dead at the hands of the Caroline barbarians) written by then provincial Fulcherio Spilimberg (1682-1750) around 1740, added him to the glorious list of Jesuit martyrs in the Philippines. If, as historian Luke Clossey argues, salvation was the main missionary motivation, Cantova unsurprisingly became a spiritual hero. ${ }^{269}$ Indeed, as Spilimberg wrote: "Ordinarily martyrs are saints before they are martyrs; because martyrdom is usually the reward and Crown of their sanctity."270

With the end of the missionary venture, Spanish interest in the Western Carolines ceased. ${ }^{271}$ The objective of Valdés y Tamón, governor general of the Philippines, was to contain the indigenous uprisings in the archipelago as well as the attacks on English and Dutch ships, thus discouraging further

268 Afterward, they wrapped his body in a mat and buried it under a hut, "which among them is an honorable grave and is only granted to the island's principals." His companions, who lived in Pohnpei, shared his fate, but their bodies were laid in a small boat that was abandoned at sea ("Carta a los RR. Jesuitas" [n.d.], in Davin, Cartas edificantes y curiosas escritas de las misiones extranjeras, 13:fols. viii-x; Astrain, Historia de la Compañía de Jesús, 7:779-81; de la Costa, Jesuits in the Philippines, 550-51; Charles E. O'Neill and Joaquín María Domínguez, S.J., eds., Diccionario histórico de la Compañía de Jesús: Biográfico-temático [DHJC hereafter] (Madrid: Institutum Historicum S.I., 2001), 639-40.

269 Clossey, Salvation and Globalization, 119-23.

270 ARSI, Philipp. 20, fols. 379-416, cited in Lévesque, History of Micronesia, 13:299.

271 Hezel, First Taint of Civilization, $5^{8-59 .}$ 


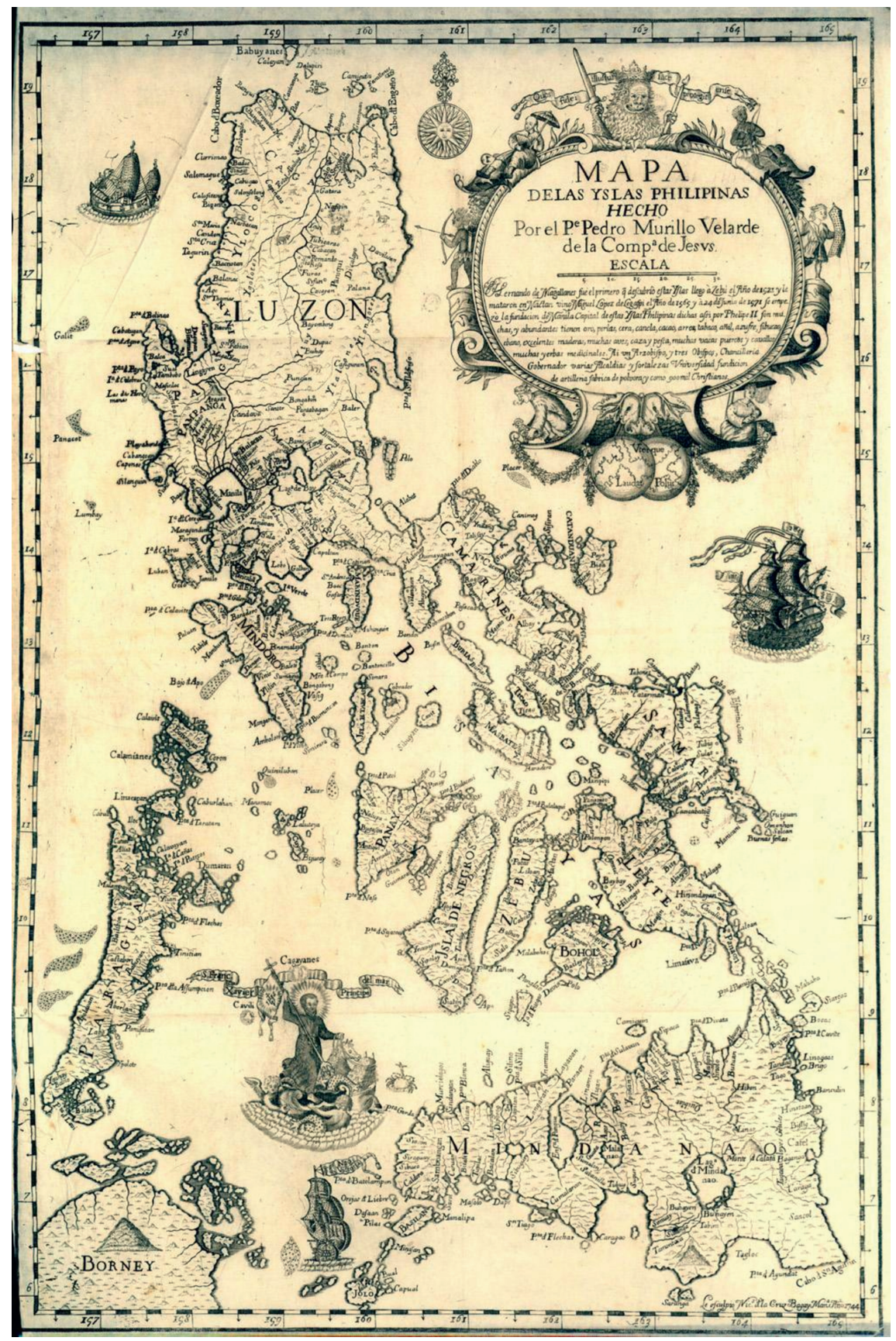

FIGURE 10 Pedro Murillo Velarde's map of the Philippines (1734) 
alliances between them that might eventually threaten Spanish sovereignty in the Philippines. With the backing of Britain's growing naval power, the British East India Company succeeded in establishing direct trade with China in $1715 \cdot{ }^{272}$ The conflicts with the old British company led to an outbreak of hostilities in the so-called War of Jenkins' Ear in October 1739, which hindered communications with Acapulco. ${ }^{273}$ At the same time, the governor general ordered Fr. Pedro Murillo Velarde (1696-1753) to draw a map and navigation chart (Manila, 1734) indicating the hydrography and topography of the Philippines and identifying the various entry points for maritime communication between Manila and the peninsula and New Spain..$^{274}$

As the eighteenth century progressed, Spain's enemies, especially the British, continued to threaten the Philippines from the Western Carolines, where they were making landfalls. As a result, the strategic location of the Pacific islands, and particularly the archipelago of the Marianas, which was of particular interest to the metropolitan authorities, prevailed over any drawbacks—or peculiarities, in the words of historian Josep Maria Fradera ${ }^{275}$ —namely the limited Spanish presence in the archipelago and the cost to the public treasury.

The Baroque Theater of Power

As discussed above, the corrupt governors of the Marianas, particularly de la Esplana and Pimentel, traded illegally with pirates and merchants from other countries, an egregious offense, especially since the island functioned as a presidio at the rearguard of the empire to protect it from the attacks of pirates and

272 Hezel, First Taint of Civilization, 61-62.

273 Vicente Rodríguez García, El gobierno de don Gaspar Antonio de la Torre y Ayala en las islas Filipinas (Granada: Universidad de Granada, 1976), 159-96; Mª Lourdes Díaz-Trechuelo López-Spínola, "Filipinas en el siglo de la Ilustración," in Cabrero, Historia general de Filipinas, 249-92, here 275 .

274 Pedro Murillo Velarde, Carta hydrographica y chorographica de las Yslas Filipinas (Manila, 1734), Madrid: Biblioteca Nacional, GM/M.XLV no. 31 .

275 As Hezel observed: "By the 1780 a steady procession of British vessels, merchantmen of the Honorable East India Company, were making landfalls in the western Carolinesespecially among the miniscule atolls southwest of Palau — on the final leg of their voyage to Canton" (First Taint of Civilization, 6o). The Marianas mission was eventually subordinated to a defensive role vis-à-vis the threat represented by the other colonial powers (Brunal-Perry, "Las islas Marianas," 554-55; Driver, Spanish Governors, 27-28). 
other nations. ${ }^{276}$ Paradoxically, as the weakness of the Bourbon dynasty embodied in the so-called benefices - the sale of administrative and judicial offices to the highest bidder, which inevitably promoted the use of these offices as economic investments - allowed local elites to associate public office with personal gain, the enlightened monarchies developed mechanisms of representation meant to encourage a patriotic sense of duty and loyalty toward the crown and its realm. ${ }^{277}$ These included a series of public rituals and ceremoniessuch as royal funerals, public prayers or rogativas, and investitures - that acted as transmission belts for the people's unconditional adhesion to the monarch. The new symbols and rituals of power, such as coats of arms, royal ceremonies, and royal portraits, sought to reinforce the Bourbon presence and sovereignty overseas, even in the distant and ill-reputed Marianas.

On July 22, 1747, the secretary of government and war in the Marianas, Jorge Eduardo del Castillo (dates unknown), visited the Jesuits' residence in Hagåtña to inform them of the death of King Philip v. ${ }^{278}$ At that time, Jacobo Heypel (1721-58), vice-provincial of the mission; Bonani, minister of the partido of Agat; Franz (Francisco Javier) Urfahrer (1724-66), minister of Inajaran, Merizo, and Umatac; Wolfgang Steinbeck, rector of the San Juan de Letrán school (in office 1734-67); and Franz Xavier (Francisco Javier) Reittemberger (1708-67), who was in charge of the evangelization of Rota, were all present. ${ }^{279}$ Castillo also notified them of his intention to hold a great celebration to honor the new king with as much pomp and splendor as possible.

To compensate for the physical distance or absence of the king, which was more accentuated in imperial and multi-territorial monarchies such as the Spanish Empire, institutional and symbolic resources were created to foster the realm's cohesion. ${ }^{280}$ Proximity to the king — or to the symbols that represented

276 The periodic arrival of Dutch ships is corroborated in the History of Morales, who confirmed the existence of "safe, deep-water ports" on the island of Guåhan, particularly that of Umatac Bay (or Humåtac), "where the Dutch who travel these seas sometimes anchor their ships" (Morales and Le Gobien, History of the Mariana Islands, 122).

277 Fernández Albaladejo, Materia de España, 210-15.

278 A copy of this decree can be found in AHCJC. FILPAS-093, doc. 66 , fols. $3^{\mathrm{v}}-4^{\mathrm{r}}$.

279 Bonani's letter to Udalrico Bombardi, Agat, December 15, 1740, transcribed in Lévesque, History of Micronesia, 13:441. By then, the Society of Jesus had four missionaries in Guåhan and one on the island of Rota. These were the only populated islands in the Marianas at that time; Procurator José Calvo's letter to King Philip v, June 20, 1737, in AHCJC. FILPAS-092, fol. $51^{\mathrm{v}}$. They were accompanied by coadjutor brother Luis García (1710-54). See also Hezel, From Conquest to Colonization, 6o, 87, 90.

280 Agustín González Enciso, "Del rey ausente al rey distante," in Imagen del rey, imagen de los reinos: Las ceremonias públicas en la España Moderna (1500-1814), ed. Agustín González 


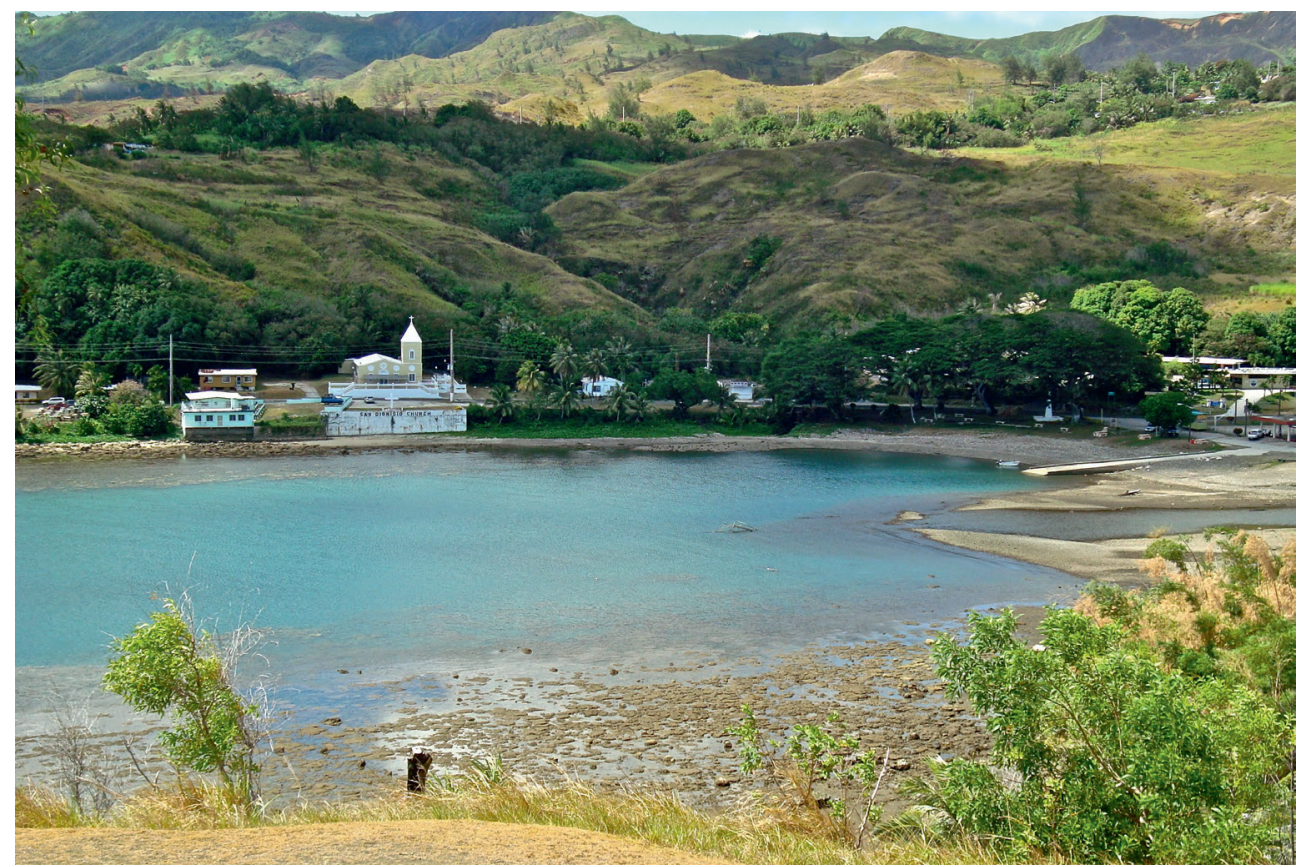

FIGURE 11 Humåtac Bay (or Umatac), Guam

PHOTOGRAPHED BY ALEXANDRE COELLO DE LA ROSA

him - marked the status of his subalterns. ${ }^{281}$ Lieutenant Governor Domingo Gómez de la Sierra (in office $1746-49)^{282}$ acted as his delegate, and the authorities throughout the empire had portraits, stamps, or small likenesses of the king to celebrate and share in the liturgy of royal power. These reproductions ensured that the monarch was symbolically present in faraway spaces, constituting fundamental elements of his sovereignty, as argued by historian Alejandra Osorio. ${ }^{283}$ Royal ceremonies completed the representational

Enciso and Jesús María Usunáriz Garayoa (Pamplona: EUNSA, 1999), 2-19, here 3; Víctor Mínguez Cornelles, Los reyes distantes: Imágenes del poder en el México virreinal (Castelló de la Plana: Publicacions de la Universitat Jaume I, 1995), 23-28.

281 Carmelo Lisón Tolosana, La imagen del rey (Monarquía, realezay poder ritual en la Casa de los Austrias) (Madrid: Espasa Calpe, 1992), 148.

282 Gómez de la Sierra went from governor of the Marianas to regidor of the Audience of Manila on September 9, 1749 (AGI, Filipinas 283, N. 11).

283 Throughout the eighteenth century, portraits were increasingly replaced by stamps, which were distributed among the assistants (Alejandra Osorio, "The King in Lima: Simulacra, Ritual, and Rule in Seventeenth-Century Peru," Hispanic American Historical Review 84, no. 3 (2004): 447-74, here 450, 471; Osorio, El rey en Lima: El simulacro real y el ejercicio del 
aspects necessary for the personalistic rule of an absolute monarchy in which the monarch was as far removed as the Spanish king from his subjects in the Pacific.

On July 27, 1747, the governor decided to hold funerary rites for the king, followed by the coronation celebration for King Ferdinand VI (r.1746-59) three days later. This was not the first time that this kind of complementary ceremony - what Osorio has called "the two faces of Janus" - took place in the Marianas. On September 21, 1725, for example, Argüelles y Valdés, lieutenant governor of the Marianas (in office 1725-30), had celebrated the crowning of Louis I (1707-24), the first-born son of King Philip v, who had abdicated in his favor on January 10, $1724 .{ }^{284}$ At the edges of the Spanish Empire, these celebrations designed to represent the figure of the monarch and reinforce the loyalty and fealty of his subjects required the collaboration of the Jesuit missionaries. ${ }^{285}$

Nonetheless, these "institution rituals," as Bourdieu would characterize them, cannot be considered a simple mechanical or epiphenomenal reflection of the political order. ${ }^{286}$ They were performative acts-historian Maurice Bloch defined them as formalized languages - that encouraged the ratification of the Catholic monarchy as well as its continuity through the willingness of the target audiences to accept given symbolic codes. In peripheral spaces, power and symbolism were interlaced in the figure of an absent monarch, represented by his own portrait, to which the governor and the civil and ecclesiastical authorities publicly displayed their compliance and obedience.

In the mid-1970s, José Antonio Maravall (1911-86) reflected on the baroque celebrations of the seventeenth century, lavish festivities during which firework displays decorated the heavens while rich tapestries and hangings and arches of triumph made out of artistically entwined branches decorated the streets. Grand catafalques and platforms were used for state funerals and

poder en la Lima del diecisiete [Lima: Instituto de Estudios Peruanos and Documentos de Trabajo, 2004], 34). However, in the Marianas, these portable graphic images had not yet replaced the visual grammar of portraits.

284 Philip v abdicated in favor of his son on January 10, 1724. Luis I was crowned on February 9 of that year, but ruled for only seven months, as he died of smallpox on August 31, 1724 at the age of seventeen, and his father resumed his reign. The fact that they learned about his coronation one year after his death in the Marianas confirms the isolation and marginality of the islands. In this regard, see AHCJC. FILPAS-093, doc. 66, fol. $3^{\text {r }}$. Driver, $E l$ Palacio, 21.

285 Osorio, "King in Lima," 473.

286 Bourdieu, "Los ritos como actos de institución," 111-23, cited in Roberto J. López, "Ceremonia y poder en el Antiguo Régimen: Algunas reflexiones sobre fuentes y perspectivas de análisis," in González Enciso and María Usunáriz Garayoa, Imagen del rey, imagen de los reinos, 19-61, here 46 . 
coronations, leading Maravall to conclude that such commemorations could only take place in big cities. ${ }^{287}$ The poverty and relative smallness of the Marianas did not, however, prevent the celebration of royal ceremonies such as those described by Maravall. The islands, far removed from the seat of the court and the king, on the periphery of an overseas periphery, are therefore an interesting counterpoint as a space in which neither the standards of the cultural trappings of the Spanish baroque nor the new aesthetic sensibility of neoclassicism were present. ${ }^{288}$

There is no denying that ritual had a didactic, propagandistic, and manipulative character, demanding the conformity of the spectators/subjects to the established symbolic codes. But precisely because of this, "official" celebrations gave way to festivities of an "unofficial" and playful nature in which the entire community could actively join as participants and not merely as an audience. ${ }^{289}$ In both cases, however, the objective was to establish a collective commitment to the monarch through ritualized behaviors that some historians have defined as the "theater of power." 290 The indissoluble unity between the crown and its subjects was presented allegorically, or, as historian Ruth A. Hill has argued, a

287 José Antonio Maravall, La cultura del barroco: Análisis de una estructura histórica (Madrid: Ariel, 1975), 265; Maravall, "Teatro, fiesta e ideología en el barroco," in Teatro y fiesta en el barroco: España e Iberoamérica, ed. José Ma Díez Borque (Barcelona: Serbal, 1986), 71-95, here 87; Antonio Bonet Correa, "La fiesta barroca como práctica del poder," Diwan 5, no. 6 (1979): 53-85. Maravall argued that baroque culture was centered on an urban social order that needed to be constantly maintained and reproduced, referring to the baroque as a historical concept that "belongs to the realm of social history" (La cultura del barroco, 48). I prefer the concept of baroque as related to certain elements of style and form that were part of the "national culture" and were present as such in the royal funeral and coronation celebrated in the 1740 s in the Marianas. On the relevance of the baroque in Spanish "national identity," see Joaquín Álvarez Barrientos, "El barroco sobre el debate dieciochesco sobre la identidad nacional," in Temas del barroco hispánico, ed. Ignacio Arellano and Eduardo Godoy (Navarra: Iberoamericana and Vervuert, 2004), 11-23; and Álvarez Barrientos, "Monarquía y nación española," in Fénix de España: Modernidad y cultura propia en la España del siglo XVIII (1737-1766), ed. Pablo Fernández Albaladejo (Madrid: Marcial Pons Historia, Universidad Autónoma de Madrid, and Universitat d'Alacant \& Casa Velázquez, 2006), 191-213.

288 Julio Seoane Pinilla, La política moral del Rococó: Arte y cultura en los orígenes del mundo moderno (Madrid: Antonio Machado Libros and Colección la Balsa de la Medusa, 200o).

289 Bourdieu, "Los ritos como actos de institución," 111-23, cited in López, "Ceremonia y poder en el Antiguo Régimen," 46.

290 Julio Pedro Viqueira Albán, Propriety and Permissiveness in Bourbon Mexico (Wilmington: SR Books, 1999), 81-86; Juan Carlos Garavaglia, "El teatro del poder: Ceremonias, tensiones y conflictos en el estado colonial," Boletín del Instituto de Historia Argentina y Americana "Dr. Emilio Ravignani" 14 (1996): 7-30. 
new concept of the Spanish community or nation was at play in which "the Spanish should embrace their king and love each other."291

In this critical context, Governor de la Sierra sought to represent the absolute power of the monarch through a series of ritualized royal protocols that underscored his authority and coherence. The logic of these ceremonial practicesthe exhibition of the king's portrait, the distribution of coins thrown into the air, bull fights, plays - was not a mere whim of the king's living representative, the governor. They reproduced the ritualized forms of "constructing" - to use historian Peter Burke's notion - the monarchy in the Marianas, an effective instrument wielded by the authorities to promote the king as a protector of his subjects' interests, to reinforce his image as a key power institution in an ordered cosmos of the Spanish world. In this respect, it is surprising that historian James B. Tueller asks himself "if King Ferdinand vi even knew where the town of Hagåtña was, and did he care that Spanish, Philippines and natives celebrated his rule?"292 It did not matter. As David Hume (1711-76) wrote in his renowned 1748 essay Of National Characters: "The same set of manners will follow a nation, and adhere to them over the whole globe, as well as the same laws and language. The Spanish, English, French, and Dutch colonies are all distinguishable even between the tropics." 293

The solemnity of the ceremonial political protocol and its public character were not constituted irrationally, as Tueller seems to suggest, but structured instead by a deep symbolism. ${ }^{294}$ And yet, the context was very dissimilar to the rich courts of New Spain or Peru described respectively by historians Alejandro Cañeque and Alejandra Osorio. ${ }^{295}$ Again, in the Marianas there was no gold, no emeralds, and no silk to decorate the king's catafalque. What was really significant in the celebrations in Hagåtña was not the largesse of the

291 Ruth A. Hill, "Conquista y modernidad, 1700-1766: Un enfoque transatlántico," in Fernández Albaladejo, Fénix de España, 52-72, here 63.

292 Tueller, "Los chamorros de Guam y la colonización española," 393.

293 John H. Elliott, Empires of the Atlantic World:Britain and Spain in America, 1492-1830 (New Haven: Yale University Press, 2007), xiv. See also Elliott, España, Europa y el mundo de ultramar (1500-1800) (Madrid: Taurus, 2009), 203.

294 In her analysis of the coronation of Philip v in Lima (1622), Alejandra Osorio concludes that "royal ceremonies made the absent king present and linked him to his vassals in a reciprocal 'pact' that was made 'true' through ritual" ("El rey en Lima," 8). More recently, Juan Carlos Garavaglia has studied the diffusion and publicity of Bourbon royalism through the funeral rites of Charles III and the proclamation of his successor in Buenos Aires (1789). Far from arbitrary, this ordering of the bodies-not of the individualsconstituted "a symbolic projection of social order" (Garavaglia, Construir el estado, inventar la nación: El Río de la Plata, siglos XVIII-XIX [Madrid: Prometeo Libros, 2007], 36-43).

295 Alejandro Cañeque, The King's Living Image: The Culture and Politics of Viceregal Power in Colonial Mexico (New York: Routledge, 2004); Osorio, “King in Lima," 450, 471. 
governor, but the capacity of the ritual festival to embody, in physical form, what was symbolic and absent. If God made kings his earthly ministers, and through them reigned over the peoples of the world, state funerals, rogativas, and consecrations reinforced the authority of these kings and that of their representatives, the governors and viceroys, who defended the divinely ordained interests of the nation. Thus, Spanish sovereignty at the confines of the empire was deeply embedded through political rites that guaranteed the continued unity of the corpus mysticum and polyticum —Castile and the Indies - with the Bourbon dynasty. 296

At this juncture, it did not seem plausible that the Spanish had any intention of abandoning the islands. Only a few years earlier, the Jesuit procurator José Calvo had requested a decrease in the number of soldiers assigned to the royal presidio, arguing that this would halt the demographic collapse of the Marianas. It would also allow for the reinforcement of the presidio of Zamboanga, favoring the spiritual conquest of the sultanates of Sulu and Tamontaca. In July 1747, only a few weeks before the celebrations took place in Hagåtña, Pedro de San Cristóbal (1695-1755) informed the monarch of his designation as new procurator of the Society in the province of the Philippines and asked for his permission to travel to Rome. ${ }^{297}$ Once there, he wrote two briefs to the Council of the Indies (August 14, 1747; January 12, 1748) requesting a license to send forty priests and four coadjutor brothers to the Philippineshe initially wanted to take sixty individuals- "given the need for them in the missions of the Mariana Islands, Zamboanga, Sulu, and Tamontaca."298

In his briefs, the procurator did not mention the need for or desirability of reducing the defenses of the Marianas. There is no doubt, however, that he talked at length about this in the Spanish court. On November 28, 1749, he wrote a letter to the archbishop of Manila asking for the suppression of the Marianas' presidio and its transfer to the island of Sulu, which, along with Zamboanga, was "a most horrible and most necessary barrier, against this

\footnotetext{
296 Osorio, "King in Lima," 472-74.

297 AHCJC. FILPAS-093, doc. 9o, fol. $63^{\mathrm{r}}$.

298 Ibid., doc. 107 , fol. $162^{\mathrm{r}}$. On December 8, 1748, Estrada, provincial of the Society of Jesus, informed Philip v that he had sent four missionaries from his province to Mindanao, Jolo, and Tamontaca. Although they were cordially received by the prince of Sulu and his retinue, the missionaries had to leave three months later because of a mutiny (RAH, Cortes $567,9 / 2675$, bundle 12, fols. 1-2). On December 18, Juan de Arechederra (1681-1751), interim governor of the Philippines (in office $1745^{-50}$ ), wrote to the king to tell him of the zeal with which the four Jesuit missionaries had carried out their efforts to convert the "Moors" of Mindanao and Sulu, "at no expenses to the Royal Treasury." The prelate's support was decisive to obtain the royal favor that procurator San Cristóbal sought from the Spanish court (RAH, Cortes 567, 9/2675, bundles 11 and 12 ).
} 
morisma [Moorish mob], achieving not only the reduction of so many gentiles that must be reduced, but also the total defense of these cristiandades [Christian communities]." 299 Despite the Jesuits' concern about the decreasing Spanish presence in the Marianas, the crown not only maintained the number of men there but in fact increased it to 156 that very year. ${ }^{300}$ Seeing that the crown was determined to maintain and strengthen these islands formerly known as the "Islas de los ladrones" (Islands of thieves), the Society included them in their request for missionaries. ${ }^{301}$

\section{9}

\section{Lights and Shadows: The Virgin of Our Lady of Light}

In the eighteenth century, the persecution of certain religious practices associated with the Jesuits, such as the devotion to Our Lady of Light, was popularized by members of the Society during the rule of Ferdinand VI and the first years of Charles III (r.1759-88), who hoped that this would halt the prominence of the competing lights of the Enlightenment philosophers. In 1758, Reittemberger founded the Congregation of Our Lady of Light in Saint Ignatius Hagåtña in Guåhan. Studying the participation of the autochthonous population in this religious brotherhood from a bottom-up analysis reveals how continuous interactions with the natives gradually transformed the mission projects initiated by San Vitores at the end of the eighteenth century. These projects defined new forms of social and political organization, which were fully adopted by the local Chamorros. However, by translating pagan (read Chamorro) ideas into Catholic concepts, the Jesuits failed to reduce Chamorros to passive subjects of colonial domination. At the turn of the eighteenth century, after years of warfare, disease, and labor force exploitation, scarcely two hundred native Chamorros survived, which led to a population collapse. Most of them were female, so that Chamorro society was able to maintain the matrilineal clan structures and the native political system, all of which was re-semanticized and incorporated into Spanish categories. ${ }^{302}$

The cult of Our Lady of Light began to spread around the Americas and the Philippines (via New Spain) from 1740 onward, and it became a cohesive force

\footnotetext{
299 "Informe sobre Marianas del padre procurador general de los jesuitas de Filipinas a fray Pedro de la Santísima Trinidad Martínez de Arizala, arzobispo metropolitano de estas islas. Colegio Máximo de San Ignacio, 28 de noviembre de 1749" (RAH, Cortes 567, bundle 12).

300 AHCJC. FILPAS-093, doc. 66, fol. $16^{\mathrm{v}}$.

301 AHCJC. FILPAS-093, doc. 92, fols. $121^{\mathrm{r}}-123^{\mathrm{v}}$.

302 Atienza, "Priests, Mayors and Indigenous Offices," 31.
} 


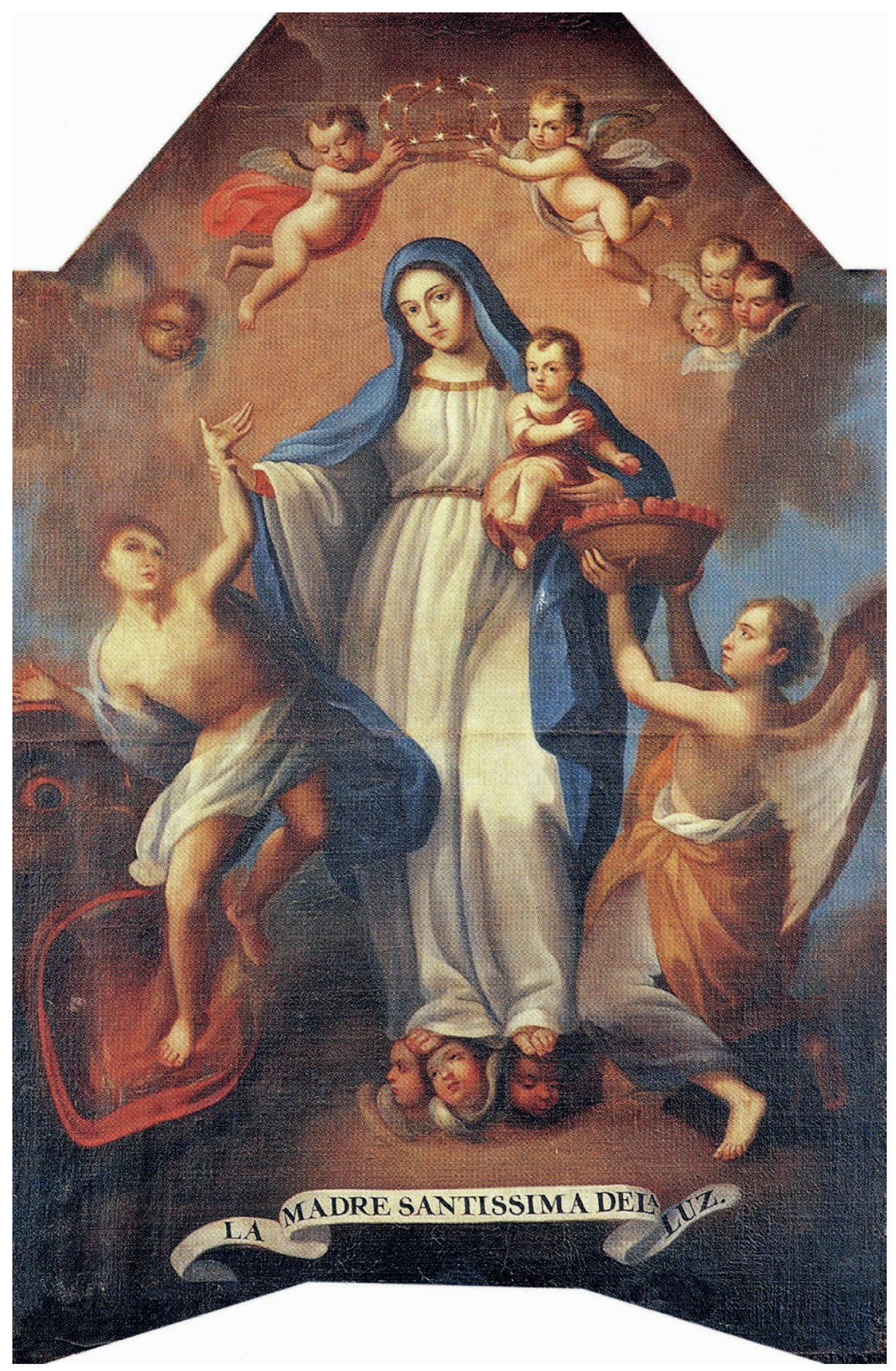

FIGURE 12 "Virgen de la Luz (siglo XVIII)." Iglesia de la reducción Ntra. Sra. Asunción (Arizpe, Mexico) 
in a multiethnic society perched on the outskirts of Spain's overseas empire. In her 1997 article, historian Pilar Gonzalbo Aizpuru states that the Jesuits emphasized the devotion to Mary to many women of all ages and directed them through the exaltation of the virtues of the housewife, thus becoming the counterpoint to the heroic sanctity of the martyrs of the Marianas. In theory, the Congregation of Our Lady of Light would provide many Chamorro women with a virtuous model through which they could imitate the values of the predominant culture. Likewise, in its different guises, this sisterhood served to stabilize the population in certain towns or regions of the island of Guåhan, thus reducing the amount of travel and facilitating their inclusion into the community of believers. These daughters of Mary Magdalene ${ }^{303}$ organized themselves to perform charitable actions and provide social assistance, and especially to detect the idolatries of local shamans_-known as makåhnas in the vernacular, and despised by the Jesuits—or scandals against morals, such as clubhouse prostitution and gambling, and to denounce them to the priest or prefect, with whom they had a close, trusting relationship. Bigamous soldiers were also the target of the vigilance of these congregants, along with schoolchildren, maidens, and the other women. In reality, a hybrid set of sexual practices was established under the auspices of Reittemberger, who appeared to be engaging in the latest iteration of mimicking native spiritual (heretical) beliefs.

After the Jesuits were expelled from the Philippines in 1769 and the Marianas in 1769 , the Chamorro women accused the deceased Reittemberger of having abused female members of the congregation. Local authorities, such as the dismissed governor José de Soroa y Lorca (in office 1759-68), as well as Captain Dionisio Garcés de Iglesias, had previously ridiculed the Jesuit priest's entanglements with these Chamorro women, claiming that "he was so charitable toward his congregation members that they gave him everything and he was a saint." ${ }^{304}$ His licentious behavior had spread around all the islands via vox populi, but the vice-provincial must have covered up the affair in order to prevent the inquisitors from learning about it.

News of the scandal spread quickly. In 1769, when King Charles III required the Spanish prelates to give their opinion on the abolition of the Society of Jesus, most of them referred extensively to the Chinese and Malabar rites, emphasizing the accusations of disobedience and idolatry. ${ }^{305} \mathrm{~A}$ year later, the

303 As is well known, Mary Magdalene was a patron saint for the redemption of prostitutes.

304 AHN, Inquisición 3730, exp. 149, fol. $5^{\mathrm{r}}$. Governor Soroa was replaced in the post by fellow ship's lieutenant Enrique de Olavide y Michelena (in office $1768-71$ ), who had already served as governor of the Mariana Islands from 1749 to $175^{6}$ (Driver, El Palacio, 34).

305 Since 1645, the Sacred Congregation for the Propagation of the Faith had censured the adoption of local practices ("Chinese rites") to evangelize the Asian people (James S. 
provincial of the Recollects (a religious order affiliated with the Augustinians), Friar José de San Buenaventura (1727-1806), wrote a letter to the king about "the thorns that the Jesuit priests have left in their doctrines," referring to the Molinist heresy detected on the Mariana Islands. ${ }^{306}$ In addition to these complaints, he reported

having found in the female sex many souls infected with the venom of the false, erroneous, and heretical doctrine, persuaded that impure touches are not sinful. But on the Mariana Islands (according to a report by the provincial vicar of these missions and other missionary ministers), Molinism has found a greater following and has been practiced with greater freedom, gathering together in a chapel of the church those who call them $[\ldots]$ to the mental prayer that they had $[\ldots]$ and mixing impurity with it. I ask for forgiveness for recounting to your Catholic Majesty the dishonesties performed to [not] offend your chaste ears. ${ }^{307}$

On August 29, 1771, Friar Antonio de Luna (in office 1768-1773), Franciscan bishop of Nueva Cáceres and apostolic governor of the vacant see in Cebu, was warned about the "dangerous Molinist sect" and urged to correct the misbehaviors detected on the Mariana Islands. The accusation was serious, bearing in mind the relationship between the polemical writings of Luis de Molina $\left(1535^{-1600}\right)$, which emphasized the unrestrained freedom of the will to attain salvation, and Jesuit moral laxity. ${ }^{308}$ Some Spanish bishops were horrified by a theological doctrine known as probabilism, which led to moral laxity, allowing a way to salvation that was too wide for their rigorist mentality. Inevitably, they

Cummins, "Palafox, China, and the Chinese Rites controversy," Revista de historia de América $5^{2}$ [1961]: 395-427; Eva María St. Clair Segurado, "El obispo Palafox y la cuestión de los ritos chinos en el proceso de extinción de la Compañía de Jesús," Studia historica: Historia moderna 22 [2000]: 145-70).

306 AGI, Philippines 627, cited in Marta María Manchado, ed., Tiempos de turbación y mudanza: La iglesia en Filipinas tras la expulsión de los jesuitas (Córdoba: Muñoz Moya, 2002), 66.

307 "Carta del provincial fray José de San Buenaventura al rey, con fecha en Manila, 29 de julio de 1770" (AGI, Philippines, 627, cited in Manchado López, Tiempos de turbación y mudanza, 66).

308 Unlike Thomistic doctrine, which emphasized the predetermination of a person's salvation by God's efficacious grace, Jesuit Molinism and probabilistic theology insisted on man/woman's choice to freely accept salvation or reject it ("facienti quod est in se Deus non denegat gratiam"). On the relationship between grace and free will to attain salvation, see Luis de Molina's Concordia liberi arbitrii cum gratice donis, diuina prcescientia, prouidentia, prcedestinatione, et reprobatione ad nonnullos primce partis Diui Thomce articulos (Lisbon, 1588). 
thought of Chinese and Malabar rites as a harmful derivation of this pernicious doctrine, as well as of Reittemberger's newly detected practices in the Mariana Islands. ${ }^{309}$ In July 1772, Bishop Luna sent a copy of the declaration made by Friar Tomás de Santa Rita (d.1806), a Recollect and Augustinian priest in the region of Inalåhan (1770-88), to ascertain whether the crimes attributed to the Jesuit were accurate. The case reached the Council of the Indies on October 10, 1772 , which once again sent it to Bishop Luna for enforcement. ${ }^{310}$

This was the last yet meaningful chapter of the Jesuit presence in the eighteenth-century Marianas. While Jesuit historiography has situated women in marginal roles, historical documentation demonstrates otherwise. Their participation in the Congregation of the Virgin of Light allowed them to preserve the essence of the Chamorro culture's vitality. By denouncing Reittemberger's abuses to the Recollects, native women challenged Spanish patrilineal standards that contradicted the traditional matrilineal bases of Chamorro society. This calls into question the practice in Western canonical historiography of emphasizing the demise of Chamorro cultural agency, viewing Spanish colonialism as an ambivalent process of control and resistance on the part of the colonizer and the colonized.

Outside the Marianas, the entire Society of Jesus was on trial. Clearly, the inquisitorial trial conducted against the Jesuit Reittemberger was the outcome of "Church anti-Jesuitism," as historian Teófanes Egido would say, on the part of the archbishop of Manila, Basilio Sancho de Santa Justa y Rufina (1728-87, in office 1767-87), whose profound antagonism toward the Jesuit order was well known. ${ }^{311}$ In addition, Dominicans, Franciscans, and Augustinians refused any adaptation or accommodation to local customs, criticizing the liberality with which the Jesuits administered the absolution of their followers in the confessional. The more rigorous and philo-Jansenist sectors accused the

309 Not surprisingly, the controversy over the Chinese and Malabar rites was one of the main arguments included in the papal brief Dominus ac redemptor promulgated on July 21, 1773, by which Pope Clement XIV suppressed the Society of Jesus (Eva María St. Clair Segurado, "Las misiones jesuíticas del Extremo Oriente en los dictámenes de los obispos españoles [1769-1770]," Revista de historia moderna 18 [2000]: 341-64, here 343).

310 AGI, Philippines 627, cited in Manchado López, Tiempos de turbación y mudanza, 65 .

311 In January 1768, Father José de Torres (d.1768), provincial of the Jesuits in the Philippines, had opposed Archbishop Basilio Sancho de Santa Justa's pastoral visit to its religious schools and parishes. This permanently marred his relations with the Society of Jesus, although he had already expressed his aversion to those he regarded as "enemies of the human genus" to Charles III (de la Costa, Jesuits in the Philippines, $582-83$ ). 
Jesuit spiritual leaders of fostering lax morals aimed at controlling the consciences of influential but compromised groups. ${ }^{312}$

The Jesuit liturgy and ministries unquestionably facilitated the Chamorros' access to the sacraments of penitence and the Eucharist, forging ties with the groups in power, which in turn provided them with better access to the indigenous communities. The Recollects were so horrified by such moral laxity that they participated in the Inquisitorial trial against Reittemberger, whose sexual impropriety was judged as heretical. If the Augustinians' commissaries used information from the natives to produce the heretic, the natives also used the Augustinian missionaries to protect Spanish Catholic rituals and practices, which were already expressions of Chamorro culture and history. For Spanish Catholic historians, the evangelization of the Marianas is about a heroic effort to convert the Chamorro heathens to Christianity, emphasizing the demise of Chamorro cultural agency. Against this canonical understanding of cultural change and continuity, historian and anthropologist Vicente M. Diaz's theoretical premise on approaching colonialism as an ambivalent process of control and resistance on the part of the colonizer and the colonized seems most apt. ${ }^{313}$ While the Spanish missionaries' narratives do not recognize aboriginal Chamorros as active agents of change in history, Reittemberger's trial demonstrates the congregants' efforts to re-configure Catholic signs and symbols as part of Chamorro culture. ${ }^{314}$

In his 1995 article, historian Norman Neuerburg examines whether the objections attributed to Our Lady of Light had anything to do with the tensions between the church and the crown in the Spain of Charles III. ${ }^{315}$ Historian Enrique Giménez has no doubt: the Holy Mother of Light was the expiatory

312 Francisco Martínez, "Las congregaciones marianas de la Compañía de Jesús y su contribución a la práctica de la caridad (siglos XVI-XVIII)," Revista de historia moderna 21 (2003): 211-38, here 226 .

313 Vicente M. Diaz, "Grounding Flux in Guam's Cultural History," in Work in Flux, ed. Emma Greenwood, Klaus Neumann, and Andrew Sartori (Parkville, Melbourne: University of Melbourne History Department, 1995), 159-171; Diaz, "Simply Chamorro: Telling Tales of Demise and Survival in Guam," in Voyaging through the Contemporary Pacific, ed. David Hanlon and Geoffrey M. White (Lanham: Rowman \& Littlefield, 2000), 141-70, here 160.

314 As Diaz notes, Chamorro Catholic faith and culture is expressed through the veneration of the Blessed Mother in the form of the local Santa Marian Kamalen. While San Vitores enjoys a privileged position in canonical church and modern history, it is the cult of Santa Marian Kamalen today that has a privileged position among the people of the Marianas and is the primary symbol of the Chamorros' Catholic legacy (Diaz, Repositioning the Missionary, 158, 179-80).

315 For an analysis of Spanish royalism and the repression of the Jesuits in Spain, see Teófanes Egido, "El regalismo y las relaciones Iglesia-Estado en el siglo XVIII," in Historia de la Iglesia en España, ed. Ricardo García Villoslada (Madrid: BAC, 1979), 125-249. 
scapegoat used by the enemies of Jesuit laxity in Spain. ${ }^{316}$ Despite the suppression of the Society of Jesus, on November 14, 1773 Pope Clement XIV (r.1769-74) renewed the Marian congregations' privileges. ${ }^{317}$ However, in 1776 Charles III enacted a Pragmatic Sanction that banned all congregations, brotherhoods, and sisterhoods. Even though devotion to Our Lady of Light as an intercessor in the salvation of souls was not outlawed on the Mariana Islands, the Augustinians presumably acted in the way that the church authorities of New Spain did, mainly the bishops of Yucatan, Durango, Puebla, Oaxaca, and Campeche, as well as the five theologians of the Fourth Provincial Mexican Council of 1771, who had strongly recommended its prohibition. ${ }^{318}$

Thus, on February 7, 1771, after hearing the theologians' concluding remarks, Archbishop Francisco Antonio José de Lorenzana y Butrón (1722-1804) read a congregation decree prohibiting this deviant devotion, "introduced by a novator, that is, an atheist," ordering that the fire-breathing Leviathan and hieroglyphics on the paintings in some Mexican churches be erased "in order to avoid the erroneous or pernicious trust that this might induce the Most Holy Virgin to remove some of the souls condemned to hell." ${ }^{319}$ Yet additionally, the bishops of Puebla de los Ángeles, Durango, and other prelates added that "all the hieroglyphics must be erased and replaced by the ones that commonly appear with images of the [Immaculate] Conception." ${ }^{220}$ Without the Jesuits' support and guidance, the congregation of Our Lady of Light ended up languishing and dying out on the Mariana Islands. ${ }^{321}$

316 Enrique Giménez, "La devoción a la Madre Santísima de la Luz: Un aspecto de la represión del jesuitismo en la España de Carlos III," in Expulsión y exilio de los jesuitas españoles, ed. Enrique Giménez (Alicante: Universidad de Alicante, 1997), 213-28.

317 DHCJ, 1:917.

318 J. Carlos Vizuete Mendoza, "En las fronteras de la ortodoxia: La devoción a la Virgen de la Luz (Madre Santísima de la Luz) en Nueva España," in Religión y heterodoxias en el mundo hispánico: Siglos XIV-XVIII, ed. Ricardo Izquierdo Benito and Fernando Martínez Gil (Madrid: Ediciones Sílex, 2011), 255-79, here 273.

319 Luisa Zahino, ed., El cardenal Lorenzana y el IV Concilio Provincial Mexicano (México, DF: Universidad Castilla La Mancha and UNAM, 1999), 604; Vizuete Mendoza, "En las fronteras de la ortodoxia," 273 .

320 Luisa Zahino, El cardenal Lorenzana, 604.

321 Today, worship of the Virgin of Our Lady of Light has disappeared on the Mariana Islands, replaced by Our Lady of the Immaculate Conception, also known as Our Lady of Camarin (Santa Marian Kamalen), as the principal symbol of local society (Marilyn Anne Jorgensen, "Expressive Manifestations of Santa Marian Camalin as Key Symbol in Guamanian Culture" [PhD diss., University of Texas, Austin, 1984], 21-22). 


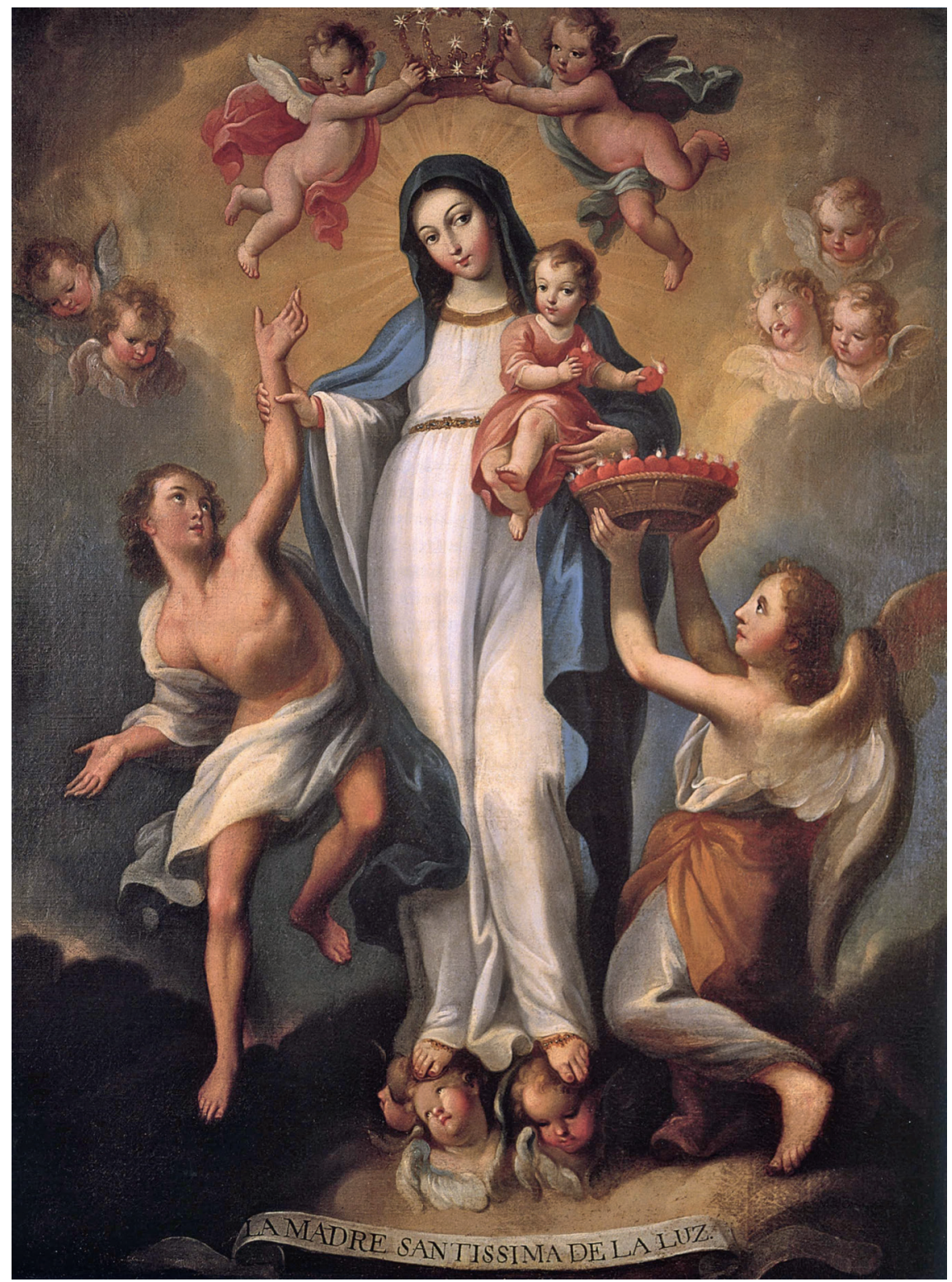

FIGURE 13 Miguel Cabrera (c.1720-68), "La Virgen de Nuestra Señora de la Luz" (eighteenth century) 
In the meantime, the summary justice against Reittemberger did not get underway until mid-1774, even though the Jesuit had died in 1767.322 This case was particularly important as it involved a religious order that Charles III and his ministers ended up expelling from Spanish lands in 1767 and that later, in 1773, Pope Clement XIV officially suppressed. ${ }^{323}$ In July 1774 , a commission was assembled to examine thirty-nine witnesses between the ages of twenty-five and sixty. ${ }^{324}$ Twenty-eight of the thirty-nine who participated in the indictment testimony were women, most of them members of the congregation of Our Lady of Light. Twenty-six questions were asked, all related to the "excesses" and "lewdness" supposedly committed by Reittemberger during the spiritual exercises.

On November 9, 1774, the commissary friar Tomás de la Rita (dates unknown) ordered that a new general nine-question interrogation be held due to the inconsistencies found in the declarations of the first witnesses gathered by Andrés de San José (dates unknown) ${ }^{325}$ in 1769 and the inquiries performed afterward. These questions revolved around the same subjects: whether they knew that Reittemberger cut the hair on the congregants' heads or "more hidden parts," whether he distributed the locks of hair to venerate as relics, whether he enclosed the congregants in the chapel of Our Lady of Sorrows and made them strip down until they were in puribus in order to do this, whether he washed their entire bodies with a handkerchief moistened with saliva, and whether he proceeded to conduct a "general hair-cutting." 326 On December 10, 1774, the commissary called Andrés de San José to testify, who promised to tell the truth in verbo sacerdotis (in the word of the priest). From his statements, it is possible to glean that many of the things that he was aware of, such as the depilatory practices, he had learned from his fellow priest, Friar Antonio de la Concepción (dates unknown), and other trusted colleagues, such as Governor Enrique de Olavide y Michelena (in office $1768-71$ ), the lay brother, Friar

322 A rumor was heard that on his deathbed he "ordered himself to be shaved because he did not want to enter heaven with a beard." Some witnesses, such as Pablo Hedde, denied this, but it confirms the impunity with which this Jesuit purportedly acted (AHN, Inquisición 3730, Exp. 149, fol. $2^{\mathrm{v}}$ ).

323 Santiago Lorenzo, "La expulsión de jesuitas filipinos: Un ejemplo de disputa por el poder político," in Giménez, Expulsión y exilio de los jesuitas españoles, 161-80.

324 AHN, Inquisición 3730, exp. 149, fols. $1^{\mathrm{v}}-6^{\mathrm{r}}$.

325 Andrés de San José, Antonio de la Concepción, and Br. Manuel de San Juan Bautista were the three Augustinian Recollects who were sent to the Marianas to substitute the expelled Jesuits in 1769 (Ángel Martínez Cuesta, O.A.R., Historia de los agustinos recoletos, vol. 1: Desde los orígenes hasta el siglo XIX [Madrid: Editorial Avgustinvs, 1995], 616).

326 AGN, Inquisición 1108, exp. 9, fols. $223^{\mathrm{V}}-224^{\mathrm{v}}$. 
Manuel de San Juan Bautista, who died in May 1771, and especially the Jesuit priest Rafael Canicia (1717-95), exiled from the islands in 1769, never to return. ${ }^{327}$

Finally, on September 23,1776 , the summary rulings were issued to the bishop of Cebu, who forwarded them to Hagåtña alleging that he did not have the authority to judge the case. Immediately thereafter, they were sent to the tribunal of the Holy Office of New Spain. ${ }^{328}$ It was not until November 20, 1776 that the rulings reached the hands of Friar Juan del Rosario (dates unknown), commissary of the Holy Office in Manila, who in turn decided to send them to be revised by Friar Santiago del Portillo (dates unknown), examiner, and Friar Juan Fernández (dates unknown) consultant of the College of Santo Tomás in Manila. Unfortunately, no information on the rulings exists. ${ }^{329}$ Nonetheless, it is known that, on July 29,1783 , the commissary of the Holy Office in Manila, Dominican friar Carlos Masvidal (dates unknown) accused San José and de la Concepción of "forcing some congregants to reveal the name of their fellows, not absolving them unless they confess." 330 Finally, on June 25, 1785, the Inquisition's commissaries resolved to put the Augustinian Recollects on trial to reveal the secret of confession. ${ }^{331}$

\section{A New Foothold in the Nineteenth-Century Carolines}

After the news of Cantova's death and the massacre of Spanish troops in 1733, the Caroline mission was abruptly closed. A century and a half later, another missionary attempt — this one successful—was made in the Western Carolines. ${ }^{332}$ In 1859 , the Jesuits returned to the Philippines after being restored to their positions there by Pope Pius VII (r.180o-23) in 1814. However, they were not entrusted with the task of opening a mission in the Western Carolines in the late nineteenth century. ${ }^{333}$ Instead, in 1881, Rome asked the Missionaries of the Sacred Heart, a congregation founded in 1854 by Jules Chevalier (1824-

\footnotetext{
327 AGN, Inquisici.n 1108, exp. 9, fols. $224^{\mathrm{v}}-226^{\mathrm{v}}$.

328 AGN, Inquisici.n 1108, exp. 9, fol. 221 $1^{\mathrm{v}}$.

329 AHN, Inquisición 3730, exp. 149, fol. $7^{\mathrm{v}}$.

330 AGN, Inquisición 1162, exp. 11, fols. $120^{\mathrm{r}}-121^{\mathrm{v}}$.

331 "Inquisidor fiscal contra fray Andrés de San Joseph y fray Antonio de la Concepción, agustinos recoletos: 1776" (AGN, Inquisición 1162, exp. [blank], fols. 55 ${ }^{\mathrm{r}}-62^{\mathrm{r}}$ ).

$33^{2}$ Hezel, First Taint of Civilization, ${ }^{8-59}{ }^{-5}$; Francis X. Hezel, Strangers in Their Own Land: A Century of Colonial Rule in the Caroline and Marshall Islands (Honolulu: University of Hawai'i Press, 2003), 14.

333 René B. Javellana, S.J., "Historiography of the Philippine Province," Jesuit Historiography Online, ed. Robert A. Maryks, http://dx.doi.org/10.1163/2468-7723_jho_COM_192583 (accessed February 14, 2018).
} 
1907) in Issoudun, France, to begin evangelization in Micronesia. As Hezel explains, a new era began on May 15, 1886 when Pope Leo XIII (r.1878-1903) issued a decree of the Society for the Propagation of the Faith, entrusting the long dormant mission to the hands of the Spanish Capuchin Friars. ${ }^{334}$

Although those remote islands had been part of Spain's colonial empire since a Spanish navigator, Francisco Lazcano (dates unknown), gave the archipelago its name in 1686, it was only in 1874 that Spain tried to reassert its old claims. Germany, Britain, and the United States had interests of a different kind in the Pacific, but Spain was the first world power to entertain the idea of creating an empire for itself in the Pacific. Now, Spain's title to the Carolines had more to do with defending national honor over the remnants of its colonial empire. 335

In January 1886, the naval frigate Marques del Duero arrived at Palau to take formal possession of the island on behalf of Spain. ${ }^{336}$ On June 29 of the same year, the steamship Manila arrived at Yap from the Philippines after a voyage of eight days carrying the first Spanish governor of the Western Carolines, Manuel de Elisa y Vergara (who would serve for a year), several minor officials, a sizable garrison of Filipino troops and their commander, and a number of Filipino convicts to assume authority over the islands for the first time. The archipelago was divided into two administrative districts: the Western Carolines, with Yap as its capital, and the Eastern Carolines, with its administrative center on Pohnpei. ${ }^{337}$

The naval bark also brought six Spanish Capuchins, three priests, and three brothers, to spread Catholicism among the heathen. ${ }^{338}$ From the very beginning, they devoted themselves to teaching the youth. In February 1891, the six Capuchins were joined by six more Spanish missionaries to found what became the first permanent mission in April 1891, the first church, which was dedicated to the Sacred Heart, and the first school in Palau in $1892 .{ }^{339}$

334 Francis X. Hezel, S.J., "Catholic Missions in the Carolines and Marshall Islands," Journal of Pacific History 5 (1970): 213-27, http://www.micsem.org/pubs/articles/religion/frames/ cathmissionsfr.htm (accessed February 14, 2018).

335 Hezel, First Taint of Civilization, 309.

336 Hezel, Strangers in Their Own Land, 3.

337 Luis Serrano and Juan Carlos Llorente, Las Carolinas orientales: 189o; La última victoria española en el Pacífico antes del eclipse (Madrid: LSV and JCLL, 2005), 36; Hezel, Strangers in Their Own Land, 9.

338 Hezel, First Taint of Civilization, 313.

339 Valentí Serra de Manresa, O.F.M.Cap., Tres segles de vida missionera: La projecció pastoral "ad gentes" dels framenors caputxins de Catalunya (1680-1989) (Barcelona: Edicions de la Facultat de Teologia de Catalunya, 2006), 538-39. 
When the Spanish Capuchins left in June 1899, the Carolines and the Marianas (except for Guåhan) were placed under the jurisdiction of the German Protectorate of New Guinea (1904). The German missionaries of the Sacred Heart went to the atoll of Jaluit, in the Marshall Islands. ${ }^{340}$ By 1906, new mission stations had opened on Likiep and Arno, and Catholic proselytism threatened the Protestant churches there. ${ }^{341}$ Although the Palauans were not enthusiastic about becoming Christians, high-ranking families were eager to send their children to the mission schools in Melekeok and Koror. Soon after the departure of the Spanish missionaries, many efforts were invested in designing a curriculum for children, which was key to understanding the Jesuit policy of education in the following years.

\section{Twentieth-Century Jesuits at the Crossroads of the New Pacific World Empires}

Shortly after the signing the Treaty of Paris with Spain on December 10, 1898, the US government reaffirmed and officially resumed the overseas expansion that the Americans had begun in the mid-nineteenth century. As historian María Dolores Elizalde Pérez-Grueso notes, "President McKinley adopted a new policy that consisted of intensifying American involvement in the international scene." ${ }^{342}$ By 1899 , he had forged a new empire. ${ }^{343}$ Strategists and officers of the US Navy set up a naval base in Manila from which to defend US interests in the Middle East. Religious organizations, including the Methodists, Baptists, Presbyterians, and Episcopalians, who were eager to develop new religious missions in the Pacific archipelago, fervently defended the US presence in the Philippines. All of these religious groups depicted the Filipinos as savages, backward, inferior in intelligence, and therefore in need of being lifted up and civilized by God's grace. ${ }^{344}$

340 Valentí Serra de Manresa, O.F.M.Cap., "Joaquim M. de Llavaneres i les missions caputxines a les illes Filipines, Carolines i Guam (Anys 1886-1913)," Analecta sacra Tarraconensia 80 (2007): 157-204, here 169 .

341 Hezel, Strangers in Their Own Land, 94-95, 124-25.

342 María Dolores Elizalde, "The Philippines at the End of the Century: Images and Reality," in More Hispanic Than We Admit: Insights into Philippine Cultural History, ed. Glòria Cano (Quezon City, Philippines: Vibal Foundation, 2014), 265-300, here 286.

343 Walter LaFeber, The New Empire: An Interpretation of American Expansion, 1860-1898 (Ithaca: Cornell University Press, 1998 [1963]), 416.

344 Elizalde, "Philippines at the End of the Century," 287; Josep Ma Delgado, "Filipinas en transición (1850-1950)," in Filipinas, un país entre dos imperios, ed. María Dolores Elizalde and Josep Ma Delgado (Barcelona: Bellaterra, 2011), 27-47, here 34-35. 
Catholic leaders were skeptical about the re-evangelization of the Philippines and the Oceanic archipelagos, but they nevertheless followed suit. ${ }^{345}$ Missionary work on the Western Carolines, however, was interrupted shortly after the outbreak of the First World War. At the end of the Spanish-American War in 1899, Spain had sold the Caroline and Marshall Islands, scattered throughout the Western Pacific, to Germany. However, the German administration was destined to be short-lived as Japan declared war on Germany in August 1914 and forced the German missionaries out of Micronesia. The pastoral actions of the Capuchin missionaries in the Marianas ended on October 14, 1914, when Rota and the rest of the islands came under the control of the Japanese after the battleship Katori came ashore at Saipan. ${ }^{346}$ As a result, the pastoral work of the first apostolic vicariate of Guåhan, which was entrusted to the Catalan Capuchins between 1911 and 1914, was very limited. ${ }^{347}$ In 1916 , all German Capuchins living in Saipan were deported, with the exception of Corbinian Vieracker (1871-1930), who left the Northern Marianas of his own volition in 1918.348 On November 30, 1915, the five German Capuchins and five Franciscan Sisters of Palau boarded a military transport bound for Japan, and a few years later, in 1919, when the Japanese forcibly expelled the last of the German missionaries stationed in Yap, the Capuchin period on the Marianas and Western Carolines came to an end. ${ }^{349}$

As soon as the Japanese won formal title to the Micronesian islands (today's Federated States of Micronesia) in 1920, Admiral Isoroku Yamamoto (1884-1943), a distinguished Catholic military official from Japan, was sent to the Vatican to request missionaries from a neutral country in response to the people's petitions for more priests. ${ }^{350}$ Mitsusada Horiguchi, the director

345 Elizalde, "Philippines at the End of the Century," 287. In 1991, Jesuit historian Francis X. Hezel published a pathbreaking book on the evangelization of Micronesia (Francis X. Hezel, The Catholic Church in Micronesia: Historical Essays on the Catholic Church in the Caroline-Marshall Islands [Chicago: Loyola University Press, 1991], 133).

346 Don A. Farrell, Rota (Tinian: Micronesian Productions, CNMI, 2004), 29; Serra de Manresa, “Joaquím M. de Llavaneres," 193.

347 Hezel, Strangers in Their Own Land, 145-46; Eric de Sinajaña, O.M.F., Cap., Historia de la misión de Guam de los capuchinos españoles (Pamplona: Curia Provincial de los Capuchinos, 2001), 43-45; Serra de Manresa, Tres segles de vida misionera, 555-59.

348 Sinajaña, Historia de la misión de Guam de los capuchinos españoles, 45.

349 Francis X. Hezel, "The Catholic Church in Yap," 2003. http://www.micsem.org/pubs/ books/catholic/yap/index.htm (accessed February 14, 2018); Serra de Manresa, "Joaquim M. de Llavaneres," 188.

$35^{\circ}$ As a result of the departure of the German missionaries from the Micronesian Islands between 1914 and 1919, the Japanese government occupied Pohnpei in 1920 and immediately afterward asked Rome "to assign to the area missionaries from some neutral country" (John F. Curran, S.J., cited in Teresa del Valle, "Approaching Missionary Activity 
of the South Sea Agency from October to November 1931, stated to the League of Nations that religion was the most appropriate and effective means of developing such a scarcely civilized people as the Micronesians. ${ }^{351}$ By early 1921, after persuading four different religious orders to take on the mission, Pope Benedict XV (r.1914-22) turned to the Jesuits and requested that the Society of Jesus, by virtue of its vow to accept any mission from the pope, assume full responsibility for the Northern Marianas mission along with the Caroline and Marshall Islands, all of which comprised Japan's South Pacific mandate (Nan'yō-chō) under the recognition of the League of Nations. ${ }^{352}$

Although the Society of Jesus had never officially returned to the Mariana Islands since the 1769 expulsion, they went to the Northern Marianas, by then politically separated from Guåhan, the southernmost and largest island of the archipelago, 158 years after they were forced to leave the strategic archipelago. On March 1, 1911, the Marianas once again joined the Caroline mission to form part of a new vicariate. ${ }^{353}$ When the German Capuchins and Sacred Heart missionaries left the mission, it was turned over to the Spanish assistancy so that, by December 1920, a contingent of twenty-two Spanish Jesuit priests and brothers had been assigned to evangelize the islands of Micronesia. ${ }^{354}$ At their head was Santiago López de Rego Labarta (1869-1941), the Jesuit superior and apostolic administrator of the Catholic Church in Micronesia. ${ }^{355}$ Finally, on May 2, 1921, a band of Spanish Jesuits arrived in Saipan to rebuild the mission that the Society of Jesus had founded in the seventeenth century.356

in Micronesia as a Genderized Phenomenon," in Micronesia: Visiones desde Europa, ed. Beatriz Moral [Madrid: Asociación Española de Estudios de Pacífico \& Ediciones Gondo, 2004], 95-113, here 98, 102).

351 Hezel, Strangers in Their Own Land, 171.

352 At the onset of the First World War, the Japanese navy invaded the Caroline and Northern Mariana Islands, leaving Guam under US naval governance (Hezel, Strangers in Their Own Land, 146-49). For the political division of the Mariana Islands, see Don A. Farrell, "The Partition of the Marianas: A Diplomatic History, 1898-1919," ISLA: A Journal of Micronesian Studies 2 (1994): 273-301.

353 Capuchin Father Salvador Walleser was named the vicar apostolic, with his residence on Pohnpei (Hezel, "Catholic Missions in the Carolines and Marshall Islands").

354 Catalogus Provinciae Baeticae (Comillas: Typis Privatis, 1926), 40-44.

355 Francis X. Hezel, "Catholic Church in Micronesia: Chuuk," 2003, http://www.micsem.org/ pubs/books/catholic/chuuk/index.htm (accessed February 14, 2018). An expedition of twenty Jesuits from Spain arrived in November 1921 to work in the Japanese territories. Five were assigned to Pohnpei, five to Chuuk, two to Yap, and four to Belau (Del Valle, "Approaching Missionary Activity in Micronesia," 98-99).

356 In 1922, the Japanese company Nan'yō Kohatsu Kaisha was formed on Saipan to found a sugar industry in the Marianas. With the spread of the sugar industry to the islands of Rota and Tinian, thousands of Okinawans, together with other migrants, 
On March 6, 1921, the first of the two ships carrying Fr. José Pájaro (1885-1934) and Br. Florencio Mancera (1891-1929) to their assignment anchored off Dublon (now known as Tonoas Island), the future administrative center of the Truk (now Chuuk) lagoon. ${ }^{357}$ After dropping off the other missionaries at their respective stations, Rego returned to Chuuk to rejoin his fellow Jesuits and the second contingent-Fr. Martin Espinal (1884-1951) and Br. Aniceto Arizaleta (1869-1945) - who arrived on the second ship. ${ }^{358}$ As the Jesuits began to inspect the mission stations, they were able to appreciate the poor condition of the Catholic missions; the chapels were in a shambles, especially after the departure of the German Capuchins. Fortunately, some months later a new contingent of Jesuits-Fr. Juan Pons (1876-1944) and Br. Miguel Timoner y Guadera (1892-1944) 359 _ arrived to take care of the Catholic community of Fefan, the third largest of the Chuuk Islands, where the Mercedarian Sisters founded a school for boarding and day students, the so-called Margarita School, which had the approval of Japanese authorities, on October 1, 1936. ${ }^{360}$

Conditions in the mission were manifestly rough at times, especially from 1921 to 1927 , when the islands depended on short-term priests and brothers, such as Pájaro, Pons, and Rego, who were transferred to other stations. In 1925, the Jesuits purchased a forty-foot sailboat, the San Ignacio, to travel to the Mortlock (or Nomoi) Islands, which, according to Espinal, was indispensable to attend to the growing number of Catholics among the Mortlockese people. Despite the scarcity of economic resources, Catholic evangelization occurred with surprising speed. From 1922 to 1925, some of the atolls of the Mortlocksfirst Lukunoch, then Moch, Satawan, Ettal, and finally Kuttu-embraced Catholicism. By 1927, there were four stone churches under construction on some of these Chuukese atolls, including Moch, Satawan, and Kuttu. ${ }^{361}$

Up to this time, the influence of Catholicism had been growing to the point that a foothold had been established on every island in the Chuuk lagoon.

inflated the population to forty-five thousand. The local Chamorro people and those of the Micronesian islands were mainly Catholic, and the Jesuit missionaries were in charge of them (Hezel, Strangers in Their Own Land, 182; John Garrett, Where Nets Were Cast: Christianity in Oceania since World War II [Suva: Institute of Pacific Studies, University of the South Pacific, 1997], 145).

357 Rufo Mendizábal, S.J., Catalogus defunctorum in renata Societate Iesu ab a. 1814 ad a. 1970 (Rome: Curia P. Gen., 1972), 325, 352.

358 Mendizábal, Catalogus defunctorum, 433, 461.

359 Mendizábal, Catalogus defunctorum, 415, 420.

360 Hezel, "Catholic Church in Micronesia: Chuuk"; Hezel, Strangers in Their Own Land, 221.

361 Hezel, "Catholic Church in Micronesia: Chuuk." 
With the collaboration of their hard-working catechists, the Jesuits were able to baptize about four thousand natives, even on the island of Weno (formerly Moen), where for years the chief Mailo had prevented the priests from entering. Opposition from Protestant pastors and the island chiefs who supported them was persistent. ${ }^{362}$

From 1927 onward, the Chuuk mission gained the required stability with new long-term personnel, such as Jesuits Jaime Batlle (1892-1965) and Faustino Hernández (1887-1945), together with Brs. Salvador Casasayas (1899?), Cipriano Martín (1883-1958), and Pedro Espuny (1892-1950), who spent twenty-five years in Chuuk. ${ }^{363}$ During this period, they not only learned the language but also became familiar with the culture of the Catholic community in the four parishes of Fefan, Weno, Faichuk, and Tonoas. ${ }^{364}$ Assisting the Jesuits in the villages was a network of efficient Chuukese catechists who concentrated on the transmission of doctrine.

One of the main patterns of Jesuit evangelization was the construction of small churches on the islands of Weno, Fono, and in the Mortlocks. Fr. Ramón Suárez (1883-1929) and Casasayas, a skilled carpenter who was to be the chief architect of the mission, excelled at building stone and wooden churches. Both men firmly believed in the power of attraction inherent in churches for non-Catholics. The German Liebenzell missionaries, who arrived in the Mortlocks in 1927, also established a significant foothold in Yap and Chuuk. They were passionate about building small churches as well, and by 1938 they had built a massive one on the island of Weno. ${ }^{365}$ Not surprisingly, Hernández complained about not being able to find more than fifty people attending the Spanish Sunday Mass from the entire island. ${ }^{366}$

After 1933, when Japan withdrew from the League of Nations, Chuuk became the administrative center for the entire mandate. Japanese, Koreans, and Okinawans came in large numbers to build new airfields and the largest naval base on Japanese Micronesian territory, bringing their whiskey and beer with them. ${ }^{367}$ The use of alcohol, which had always been prohibited to Chuukese people, created so much social disruption that the Jesuit missionaries feared for the gradual extinction of the people. At the same time, modernization

\footnotetext{
362 Hezel, "Catholic Church in Micronesia: Chuuk."

363 Mendizábal, Catalogus defunctorum, 421, 549.

364 Hezel, "Catholic Church in Micronesia: Chuuk." See also Garrett, Where Nets Were Cast, 295 .

365 Garrett, Where Nets Were Cast, 450.

366 Hezel, "Catholic Church in Micronesia: Chuuk."

367 Hezel, Strangers in Their Own Land, 217.
} 
meant new opportunities for making money, and the Chuukese began to move to Pohnpei to work on the new plantations or seek out wage labor on Tonoas. ${ }^{368}$

By 1940, Micronesia was a battleground. In February 1941, the Japanese Fourth Fleet moved its headquarters to Chuuk. Because of a new shortage of personnel, the Jesuits had once again to resort to local catechists in the villages to instruct the people in the faith, although they often lacked money to pay them. Casasayas, the architect-in-chief, traveled to the outer islands begging for food for the boarding students in Chuuk. On December 8, 1941, a day after the surprise Japanese attack on Pearl Harbor, four Jesuits, including Casasayas, were imprisoned by the Japanese on Tonoas and accused of sending signals to the US enemy. ${ }^{369}$ After being released, the Jesuits of Chuuk were transferred from Tonoas to the village of Enin. In September 1942, they were confined under house arrest in Tonoas, where they were subjected to ongoing relocations, bombing raids, and food shortages. By late 1945, when peace was finally restored, the mission had been reduced to rubble.

13

Yap

On March 14, 1921, two Jesuits-Fr. José M. Gumucio (1875-1957) and Br. Ramón Unamuno (1866-1933) ${ }^{370}$ —arrived on the island of Yap to re-establish the Catholic mission there. From the beginning, Toshiro Tezuka, the first civilian director of Nan'yō-chō (in office 1922-23), was quite favorable to the Jesuit mission on Yap, providing a generous government subsidy that helped the Jesuits cope with the mission's shattered economy. The Capuchin residence was in disrepair, and the people of Yap were not enthusiastic about joining the church. Their inconsistency, to borrow Brazilian anthropologist Eduardo Batalha Viveiros de Castro's famous expression regarding the inconsistency of the Indian soul, ${ }^{371}$ seemed to be the hallmark of Yapese religiosity. ${ }^{372}$

The Jesuit strategy did not consist of gathering the natives to set up a mission station from the start like the Capuchins had done before, but rather traveling continuously to different parts of the island. This was the job of Bernardo de la Espriella y Mosquera (1890-1945), who was aided by a group of Yapese catechists

\footnotetext{
368 Hezel, "Catholic Church in Micronesia: Chuuk."

369 Hezel, Strangers in Their Own Land, 221.

370 Mendizábal, Catalogus defunctorum, 344, 498.

371 Eduardo B. Viveiros de Castro, A Inconstância da Alma Selvagem e Outros Ensaios de Antropologia, São Paulo: Cosac \& Naify, 2002.

372 Francis X. Hezel, "Catholic Church in Micronesia: Yap," 2003, http://www.micsem.org/ pubs/books/catholic/yap/index.htm (accessed February 14, 2018).
} 
responsible for preaching to their own people. ${ }^{373}$ After 1925, the natives who were reluctant to abandon their religious practices expressed a growing interest in attending Mass and daily services. This was related to the conversion of some of the highest chiefs and the additional conversion of a renowned sorcerer from Gilfith who, having failed to protect the islanders' houses from the devastating typhoon of 1925 with his magic, requested baptism. Between 1925 and 1930, the Jesuit superior reported one thousand conversions on Yap. The number of Christians had increased from four hundred in 1921 to 1,500 in 1930 .

The Jesuits then decided to move on and visit the outer islands to bring the Gospel as well. In February 1928, de la Espriella sailed for Ulithi, where he preached in a large canoe house at Asor and Falalop. While the natives there were quite interested in the new religion, those who met de la Espriella at Mogmog were not. However, the Jesuit priest was fortunate to have the assistance of a group of dedicated Ulithians, who paved the way for the evangelization of more distant islands. In 1932, de la Espriella sailed again to visit the far-off atolls that had not yet been evangelized, such as Sorol, Ifaluk, Fais, and Woleai, where he spent three months. There, he faced strong opposition from the village chiefs, whose influence over the natives made conversion difficult. ${ }^{374}$

By 1936, the final resistance to Christianity had come to an end. The last sorcerers in Yap who had strongly opposed the new religion rejected the old beliefs and became Christians. Espriella, in particular, was a very active missionary. While concluding the construction of a new church in Wanyan village (today's Gagil municipality), he was able to tend to the northern and eastern parts of Yap. From the beginning, the Jesuits focused on training a certain number of zealous catechists who were expected to provide instruction on Christian doctrine to their own people.

Between 1934 and 1938, Fr. Luis Blanco Suárez (1896-1944) went to Ulithi, Fais, and Ifaluk to strengthen the Christian communities there. ${ }^{375}$ During his 1938 visit to the coral atoll of Lamotrek, located southeast of the Yap islands, he found people very receptive to his teaching. After three months on the islet, he baptized half of the population along with four young natives from Satawal, an islet located forty-three miles east of Lamotrek, who would be in charge of spreading the faith on their own island. Despite the lack of resources and travel restrictions on the part of Japanese authorities, in 1941, after twenty years' working on Yap, the Jesuit missionaries succeeded in converting two thousand

373 Hezel, "Catholic Church in Micronesia."

374 Hezel, "Catholic Church in Micronesia."

375 Hezel, "Catholic Church in Micronesia." 
members of the island's population and constructing seven chapels scattered over the atolls of the area, a major accomplishment. The biggest problem, as Hezel rightly observed, was how to assist the new converts in the Christian faith in the midst of a war. ${ }^{376}$

Since 1920, Palau had also been the capital of Japan's Micronesian empire. On March 16, 1921, four Jesuits-Frs. Indalecio Llera (1866-1947) and Marino de la Hoz (1886-1945), and Brs. José Gogénola (1876-1948) and Emilio Villar (1893-?) — were assigned to Palau, which formed part of the western chain of the Caroline Islands. ${ }^{377}$ They received a warm welcome from several Catholics who gathered to meet them. Among the Palauans in loincloths were representatives of the Chamorro community, who escorted the new missionaries from the dockside to the Koror church. After visiting the Christian communities on other parts of Palau, it became apparent that the picture was bleak. The mission buildings were so utterly devastated that the Jesuits could scarcely recognize any trace of the foundations. Melekeok, once the largest mission station outside of Koror, was in ruins. Natural disasters, such as the 1922 typhoon, had destroyed what still remained standing of the mission buildings. From 1923 on, the Jesuits focused on Koror, which rapidly became a sizable little town. ${ }^{378}$

In April 1921, the ship left for Ponapé (now Pohnpei), one of the Senyavin Islands, also part of the larger Caroline group. The aim was to drop off four more Jesuit missionaries-Frs. Luis Herrera (dates unknown) and Pedro Castro (1871-1963) and Brs. Victoriano Tudanca (1889-1932) and Paulino Cobo (1895-?) — to reopen the parish in Kolonia, where most of the impressive buildings constructed by the Capuchins were in good shape. Although some of the flock had drifted away, the Jesuits witnessed how well the foundation for the young church on Pohnpei had been laid by their German predecessors, who had spent over thirty years planting the seed of faith. As a result, Masses were crowded with people who had learned this devotion from the Capuchins. The Jesuits soon began regular catechism classes for the children, and even won converts from among the numerous Protestants on the island. ${ }^{379}$

376 Hezel, "Catholic Church in Micronesia."

377 Mendizábal, Catalogus defunctorum, 421.

378 Hezel, Strangers in Their Own Land, 174-85.

379 Francis X. Hezel, "Catholic Church in Micronesia: Pohnpei," 2003, http://www.micsem .org/pubs/books/catholic/pohnpei/index.htm (accessed February 14, 2018). 
In January 1922, three more Jesuits arrived, and a third parish was reopened in Awak in the north. For the next twenty years, there would be three parishes there, with a priest and a brother living in each. With these parishes staffed and functioning, the missionaries expanded their scope to the outer islands, which no religious order had ever visited. In August 1922, Herrera, along with his catechist Luis, took a small copra steamer to the island of Ngatik, where some children were baptized and a flourishing community of over a hundred was consolidated. However, attempts to convert other islands, such as the Kapingamarangi and Nukuoro atolls, were unsuccessful. For this reason, and because the new parish in Awak turned out to be more demanding than expected, the Jesuits decided to attend to their own growing community. Unlike the Palau mission, where only half of the small Catholic congregation in Airai bothered to show up for Mass, the parishioners on Awak attended church in great numbers, and the parish congregations were very active. ${ }^{380}$

In the summer of 1923, an unfortunate incident occurred when the church of Awak burned down. ${ }^{381}$ In July 1926, Fr. Higinio Berganza Pinedo (1892-1973) was temporarily assigned to Pohnpei as pastor of Kolonia, where he spent nine years. The new building was ready a few months later, on December 8, 1926, when it was solemnly consecrated. ${ }^{382}$ Fr. Santiago López de Rego y Labarta (1869-1941), who had been consecrated bishop in Tokyo on August 26, 1923, was placed in charge of the vicariate. ${ }^{383} \mathrm{He}$ made his first episcopal visit to Pohnpei to meet with his fellow Jesuits and bless the new church. ${ }^{384}$

Meanwhile, Berganza was stationed at the Kolonia parish where he served as pastor for the next nine years. There, he experienced the same problems as the other Jesuits with regard to opening elementary schools. Under Japanese civilian rule, this enterprise was futile, since the government jealously assumed

38o Francis X. Hezel, "Catholic Church in Micronesia: Palau," 2003; http://www.micsem.org/ pubs/books/catholic/palau/index.htm (accessed February 14, 2018).

381 Garrett, Where Nets Were Cast, 449.

382 Hezel, "Catholic Church in Micronesia: Pohnpei."

383 As Francis X. Hezel notes, "the Vicariate of Micronesia was established by decree in 1844 but neglected in favor of missionary work in other parts of Oceania" (Hezel, "Catholic Church in Micronesia: Marshalls," 2003, http://www.micsem.org/pubs/books/catholic/marshalls/index.htm?PHPSESSID=7c2ff85adb5766a972c7f2f 21 cf4feo5 [accessed February 14, 2018]. See also Hezel, "Catholic Missions in the Carolines and Marshall Islands").

384 In Tokyo on August 26, 1923, Father Rego was consecrated bishop and placed in charge of the vicariate. A short biography of Father Rego appeared in serialized form in the mission magazine El ángel de Carolinas right after his death in 1941 (Francis X. Hezel, "Catholic Missions in the Carolines and Marshall Islands," Journal of Pacific History 5 [1970]: 213-27). See also Francisco Delgado and Francis X. Hezel, "Santiago López de Rego Labarta," in DHCJ, 3:2417-18. 
a near monopoly over formal education. ${ }^{385}$ In addition, all teaching had to be conducted in Japanese. The only solution, according to the missionaries, was to establish boarding schools to provide the boys with meals and instruction. In November 1928, four Mercedarian Sisters of Berriz arrived in Pohnpei. Mother Margarita María López de Maturana (1884-1934), the superior general of the order (in office 1931-34), supported the Jesuits and opened a girls' dormitory with twenty girls. ${ }^{386}$

As the 1930s began, the number of Catholics in Ponhpei grew from 1,400 in 1921 to about three thousand by 1934. Meanwhile, the number of Japanese and Okinawans also increased, which boosted commercial productivity, bringing the natives into contact with the dangers of materialism and leading them to neglect their religion. The civil governor, who had always been tolerant with the missionaries, began to regard Catholicism as a rival for the full allegiance of the Micronesian people. ${ }^{387}$ No dissent was permitted, especially when the Japanese military began to organize male gangs and send all ablebodied Pohnpeians to labor in the phosphate and bauxite mines on Angaur and Fais. ${ }^{388}$ Other Yapese natives were recruited to work in the plantations of Pohnpei. The impact of the Japanese modernization programs also changed Yapese habits related to consumption and stability. The Pohnpeians had no time to attend religious instruction or daily services, and more often than not, men took advantage of the easy access to alcohol. ${ }^{389}$ Additionally, when massive Japanese immigration increased, so did the number of Japanese students, and the number of public schools increased throughout the 1930s. At the same time, expansion of the school system for Micronesians all but ended in 1931. As a result, the Jesuit priests had serious problems instructing the native converts and providing for their pastoral needs. ${ }^{390}$

In order to counteract the negative influence of the public schools and growing materialism, Bishop Rego appointed Br. Cobo to take over the operation of the boarding school following the death of Br. Francisco Burzaco (d.1945) in late 1932. As Hezel has noted, after fifty years stationed on Ponhpei, Cobo became a devoted priest, a self-sacrificing teacher and counselor, becoming one of the most charismatic Jesuits in Micronesia. ${ }^{391}$ The Catholic community

\footnotetext{
385 Hezel, Strangers in Their Own Land, 172.

386 Hezel, "Catholic Church in Micronesia: Pohnpei."

387 Hezel, "Catholic Church in Micronesia: Pohnpei."

388 By 1913, the phosphate mines proved extremely profitable, producing nineteen thousand tons a year (Hezel, Strangers in Their Own Land, 123, 218).

389 Hezel, "Catholic Church in Micronesia: Pohnpei."

390 Hezel, "Catholic Church in Micronesia: Pohnpei." Hezel, Strangers in Their Own Land, 193.

391 Hezel, "Catholic Church in Micronesia: Pohnpei."
} 
was also slowly growing in the south in Protestant strongholds. ${ }^{392}$ In addition to the three main parishes (Kolonia, Awak, and Kitti), the Jesuit missionaries planned to develop some smaller stations on the island, such as Tamworoi and Seinwar, where a little wooden church and a chapel were built.

Other dedicated Jesuits, such as Francisco (Quirino) Fernández (18871945), ${ }^{393}$ who arrived in Ponhpei in 1935 to replace Berganza as pastor of Kolonia, wrote desperately to the Jesuit superiors in Spain for money to build the new boys' dormitory that the missionaries had long planned to construct. Additionally, Fernández, the appointed local Jesuit superior, "envisioned setting up inexpensive shelters that could serve as sleeping quarters when Pohnpeians came into Kolonia either for Mass or for medical attention at the Japanese hospital." ${ }^{394}$ However, none of these projects was fully completed due to the threat of war across Micronesia.

In December 1932, the League of Nations censured Japan for its aggression against Manchuria. ${ }^{395}$ As a result of Japan's increasing militarism, conditions on Pohnpei worsened. The Spanish Jesuits were denied access to some islands, such as Peleliu (or Beliliou). ${ }^{396}$ However, despite the restrictions on the movements of the foreign missionaries, the churches were full and the number of Catholics, far from diminishing, rose to 3,60o, for the first time exceeding the number of Protestants. Notwithstanding, as Japan was on the brink of war, "Japanese authorities curtailed the work of the missionaries, later confining them to their own rectories and moving them even from these as suited the Japanese military."397

The Jesuits also visited the Marshall Islands, where they had never been before, after they were united with the Carolines and the Marianas to form a single vicariate. ${ }^{398}$ It was not until 1922 that the Society of Jesus was asked to take

\footnotetext{
392 Garrett, Where Nets Were Cast, 449.

393 Garrett, Where Nets Were Cast, 421.

394 Hezel, "Catholic Church in Micronesia: Pohnpei."

395 Hezel, Strangers in Their Own Land, 207.

396 Hezel, Strangers in Their Own Land, 216.

397 Hezel, "Catholic Missions in the Carolines and Marshall Islands."

398 Decree of the Society for the Propagation of the Faith, May 4, 1923, Acta Apostolicae Sedis Xv (1923), 336-37, cited in Hezel, "Catholic Missions in the Carolines and Marshall Islands."
} 
full responsibility for the evangelization of the Marshalls. ${ }^{399}$ Rego, the apostolic administrator of the vicariate, proposed opening two houses in the island group. To do so, he counted on the collaboration of four Jesuits; in early January 1922, Pájaro, a reputed linguist, and Tudanca were assigned to reopen the old German mission on Jaluit, while Ramón Suárez and Br. Francisco Hernández Escudero (1887-1944) went to the station at Arno. ${ }^{400}$ As usual, they wondered at the marvels that the German Capuchins and Sacred Heart missionaries had performed in the Marshalls, especially in a religious milieu dominated by Protestantism. In particular, the Jesuit missionaries recognized the importance of focusing on education, and they reopened the boarding school in Jaluit. Pájaro was the best prepared to run the school since he was fluent not only in Japanese, the only language allowed under government regulations, but also English, which provided a good incentive for parents to send their children to the Jesuit school. However, his educational and missionary work was interrupted by a serious illness that required him to leave the Marshalls to recover.

In the meantime, Bishop Rego was hesitant to continue working in such unproductive stations in the Marshalls, especially when other parts of Micronesia were clamoring for priests. In 1926, after a two-year absence, Antonio Guasch i Bufí (1879-1965), who had served in Japan as mission procurator and university professor, was assigned to Jaluit with Espuny. ${ }^{401}$ However, this new attempt to resume the Marshallese stations was futile. In early 1934, Pájaro became sick again, and this time, he did not recover. His death meant the end of a permanent residence in the Marshalls. To attend to the Catholics of Jaluit, Berganza, the new Jesuit mission superior at Ponhpei, made yearly pastoral visits to administer the sacraments for the small Catholic community there. ${ }^{402}$ In August 1939, he left the mission for Tokyo to learn Japanese and was replaced by Gregorio Fernández (dates unknown), who focused on working with the youth.

After the beginning of the First World War, Japanese naval strategists started to construct airfields and port facilities in the Marshalls. To do so, the male population was conscripted in great numbers to the sites of the military bases, which produced significant dislocation among the natives. ${ }^{403}$ As the Marshall Islands were converted into military bases, Spanish Jesuit activity abruptly ended in 1940. In the opinion of Hezel, "Spanish Jesuits, unused to the demands of apostolic work in a religiously pluralistic society, were probably not

399 Hezel, "Catholic Missions in the Carolines and Marshall Islands," 213-27.

400 Mendizábal, Catalogus defunctorum, 326, 339.

401 Mendizábal, Catalogus defunctorum, 457.

402 Hezel, "Catholic Church in Micronesia: Pohnpei."

403 Hezel, Strangers in Their Own Land, 217, 225. 
the missionaries best suited to staff the Marshalls." Nonetheless, by 1940 they registered a church enrolment of over five hundred, a doubling of the size of the Catholic community in twenty years. ${ }^{404}$

\section{Conclusion}

To paraphrase Christian apologist Tertullian (c.155-c.240 CE) in his Apologeticum, the blood of the martyrs continued to be the seed of the Catholic Church in Micronesia (shortly after the outbreak of the Second World War, the islands acquired great importance for the Japanese as staging areas and military bases to expand south). As a result, conditions changed considerably for the Catholic missions. In August 1942, two Sacred Heart priests, Louis Durand and Leon Marquis, left the Gilbert Islands in a large canoe to seek refuge on another island. They drifted at sea for three weeks until they finally made landfall on Mili Atoll in the Marshall Islands. The Japanese military police caught the French priests and interrogated them; they were later found bullet-ridden, and their bodies were buried by some Gilbertese Catholics. ${ }^{405} \mathrm{In}$ July 1944, as the Allies were advancing through the western Pacific, a sense of desperation grew among the Japanese military. The three Jesuit missionaries working on the nearby island group of Yap, Blanco, de la Espriella, and Hernández, were sent to Palau by the Japanese military police. Suddenly, on the evening of September 18, shortly before the US invasion of Palau, the three Jesuits on Yap, together with another three Jesuits working in Palau, Frs. Elias Fernández González (1880-1944), Marino de la Hoz del Canto (1886-1945), and coadjutor brother Emilio del Villar Blázquez (1893-1944), were forced to kneel alongside a large trench where they were either beheaded or shot to death by the Japanese military police and buried in a mass grave. With them died a Filipino Chamorro family from Yap as well. ${ }^{406}$ After the war, the Japanese authorities claimed that the six Jesuits and the Catholic family had been sent to the Philippines in September 1944 on a transport that was torpedoed and sunk. ${ }^{407}$ As Hezel remarks, although this story was easily disproved, the exact fate of the missionaries is unclear. More likely than not, "their bodies were dug up and cremated, but the gravesite remains unknown to the present day." 408

\footnotetext{
404 Hezel, "Catholic Church in Micronesia: Marshalls."

405 Hezel, "Catholic Church in Micronesia: Marshalls"; Garrett, Where Nets Were Cast, 121.

406 Hezel, Catholic Church in Micronesia, 30; Hezel, "Jesuit Martyrs in Micronesia."

407 Hezel, "Catholic Church in Micronesia: Palau."

408 Hezel, "Catholic Church in Micronesia: Yap."
} 


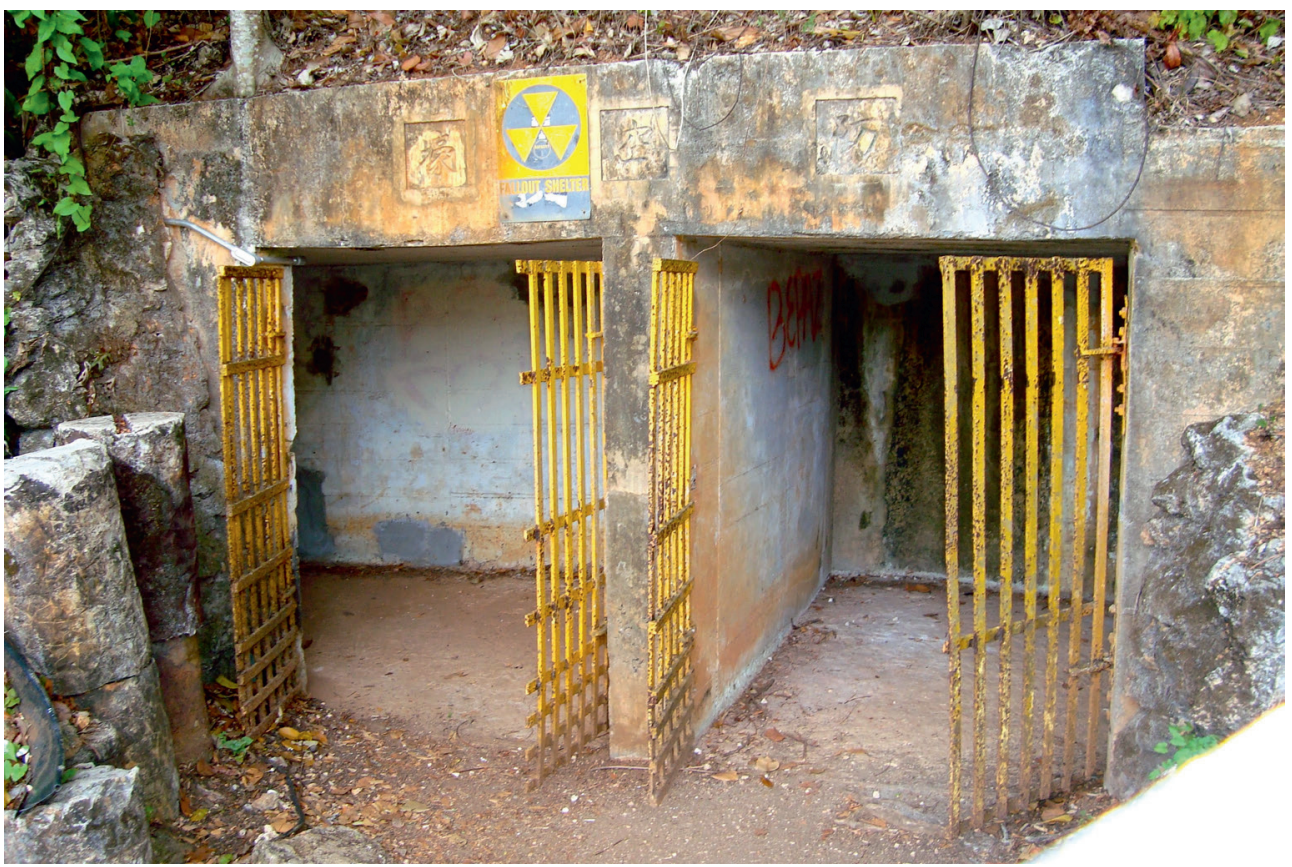

FIGURE 14 Japanese bunker, Guam

PHOTOGRAPHED BY ALEXANDRE COELLO DE LA ROSA

Unfortunately, these were not the only cases of this type. One more Jesuit brother, Timoner, met a violent death at the hands of the Japanese during the final days of the Second World War. Beginning in 1941, Christian leaders were suspect and under surveillance on Saipan. After several years working on the island of Rota as Pons's assistant, Timoner, along with five Catholics from Rota, was transferred to Saipan and imprisoned for several months on charges of espionage. Finally, in November 1944, Timoner and his five companions were beheaded and their bodies buried secretly, thereby extending the list of Micronesian martyrs for Catholicism. ${ }^{409}$

As this paper has shown, the history of the Jesuits' involvement in the Western diaspora to the islands of Oceania demonstrates that they were not simply agents of the colonial powers; rather than strictly carrying out orders issued from the center, they adapted their missionary strategies as a result of the interplay between local conditions and long-distance networks. In order to understand the rise and fall of Jesuit evangelization in Oceania from the

409 Hezel, "Jesuit Martyrs in Micronesia." 


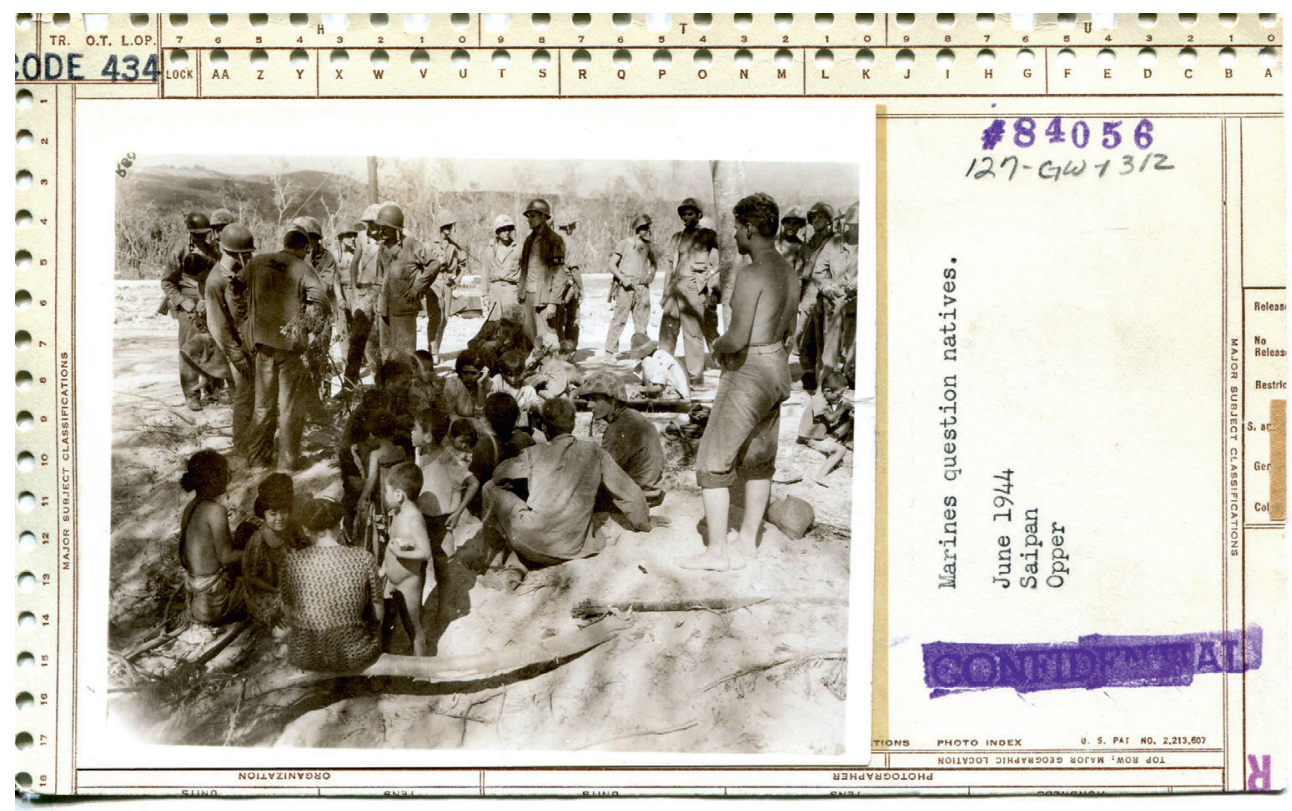

FIGURE 15 United States Marine Corps photograph \#84555; Records of the United States Marine Corps, Record Group 127-GW

COURTESY OF THE NATIONAL ARCHIVES AT COLLEGE PARK, MD

seventeenth to twentieth centuries, it is important to place Micronesia into the broader context of Philippine politics. In addition, new scholarship has also highlighted the way in which native peoples were capable of incorporating and re-semanticizing previous elements of contact in new twentiethcentury colonial (German, Japanese, US) scenarios. Despite the disruptive effects of militarization and forced Catholicization, over time they indigenized European practices and Westernized indigenous elements in a complex historical dialogue. ${ }^{410}$

410 David Atienza de Frutos, "The Mariana Islands Militia and the Establishment of the 'pueblos de indios': Indigenous Agency in Guam from 1668 to 1758," Second Marianas History Conference, 2013. For an essentialized perspective of Chamoru identity, see Jonathan Blas Diaz, Towards a Theology of the Chamoru: Struggle and Liberation in Oceania (Quezon City: Claretian Publications, 2010), 28-70. 


\section{Bibliography}

Acosta, José de, S.J. Historia natural y moral de las Indias. Critical edition by Fermín del Pino Díaz. Madrid: csic, 2008.

Aguilera Fernández, María. "La reimplantación de la Compañía de Jesús en Filipinas: De la restauración a la revolución filipina (1815-1898).” PhD diss., Universitat Autònoma de Barcelona, 2018.

Alcalá, Luisa Elena. Fundaciones jesuíticas en Iberoamérica. Madrid: Fundación Iberdrola, 2002.

Álvarez Barrientos, Joaquín. "El barroco sobre el debate dieciochesco sobre la identidad nacional." In Temas del barroco hispánico, edited by Ignacio Arellano and Eduardo Godoy, 11-23. Navarra: Iberoamericana and Vervuert, 2004.

Álvarez Barrientos, Joaquín. "Monarquía y nación española." In Fénix de España: Modernidad y cultura propia en la España del siglo XVIII (1737-1766), edited by Pablo Fernández Albaladejo, 191-213. Madrid: Marcial Pons Historia, Universidad Autónoma de Madrid, and Universitat d'Alacant \& Casa Velázquez, 2006.

Álvarez, Luis Alonso. "Repartimientos y economía en las islas Filipinas bajo dominio español, 1565-1815." In El repartimiento forzoso de mercancías en México, Perú y Filipinas, edited by Margarita Menegus, 170-216. México, DF: Instituto de Investigaciones Dr. José María Luis Mora and Centro de Estudios sobre la Universidad, 2000.

Aristotle. Politics. Translated by Ernest Baker. Oxford: Clarendon, 1946.

Astrain, Antonio, S.J. Historia de la Compañía de Jesús en la asistencia de España. Vol. 6. Madrid: Administración de Razón y Fe, 1925.

Atienza de Frutos, David. "The Mariana Islands Militia and the Establishment of the 'Pueblos de Indios': Indigenous Agency in Guam from 1668 to 1758 ." Second Marianas History Conference, 2013.

Atienza de Frutos, David. "Priests, Mayors and Indigenous Offices: Indigenous Agency and Adaptive Resistance in the Mariana Islands (1681-1758)." Pacific Asia Inquiry 5, no. 1 (2014): 31-48.

Bailyn, Bernard. "Introduction: Reflections on Some Major Themes." In Soundings in Atlantic History: Latent Structures and Intellectual Currents, 1500-1830, edited by Bernard Bailyn and Patricia L. Denault, 1-8. Cambridge: Cambridge University Press, 2009.

Ballantyne, Tony, and Antoinette Burton. "Introduction: Bodies, Empires, and World Histories." In Bodies in Contact: Rethinking Colonial Encounters in World History, edited by Tony Ballantyne and Antoinette Burton, 1-15. Durham, NC: Duke University Press, 2005.

Banchoff, Thomas, and José Casanova. "Introduction." In The Jesuits and Globalization: Historical Legacies and Contemporary Challenges, edited by Thomas Banchoff and José Casanova, 1-13. Washington, DC: Georgetown University Press, 2016. 
Baró i Queralt, Xavier. Misioneros en el Pacífico: Los intentos de evangelización de las islas Marianas y Palaos (1710-1733). Girona: Documenta Universitaria, 2013.

Baró i Queralt, Xavier. "La primera mundialización y la mirada sobre el otro: Las misiones jesuíticas en ultramar." In A vueltas con el pasado: Historia, memoria y vida, edited by Joan-Lluís Palos and Fernando Sánchez-Costa, 129-51. Barcelona: Publicacions de l'Universitat de Barcelona, 2013.

Barratt, Glynn. The Chamorros of the Mariana Islands: Early European Records, 15211721. Saipan: Division of Historic Preservation and the Micronesian Area Research Center, 2003.

Barrett, Ward. "Preface." In Mission in the Marianas: An Account of Father Diego Luis de Sanvitores and His Companions (1669-1670), 1-62. Minneapolis: University of Minnesota Press, 1975 .

Batllori, Miquel. Les reformes religioses al segle XVI. Barcelona: Biblioteca d'Estudis d'Investigació, Tres i Quatre, 1996.

Bernabéu Albert, Salvador. "Las utopías y el reformismo borbónico." In El reformismo borbónico: Una visión interdisciplinar, edited by Agustín Guimerá, 247-64. Madrid: Alianza Universidad, 1996.

Bonet Correa, Antonio. "La fiesta barroca como práctica del poder." Diwan 5, no. 6 (1979): 53-85.

Borja de Medina, Francisco, S.J. "El Real Colegio-Seminario de San Juan de Letrán de las islas Marianas: El sueño del Beato Diego Luis de Sanvitores, S.J., y su realidad cotidiana (1669-1768)." Conference in XII Misiones Jesuíticas: Jornadas Internacionales, Interacciones y sentidos de la conversión, September 26, 2008, Buenos Aires, Argentina.

Bourdon, Léon. La Compagnie de Jésus et le Japon, 1547-1570. Lisbon: Centre Culturel Portugais de la Fondation Calouste Gulbenkian, 1993.

Boxer, Charles Ralph. The Christian Century in Japan, 1549-1650. Berkeley: University of California Press, 1967 .

Boxer, Charles Ralph. "Two Jesuit Letters on the Mariana Mission, Written to the Duchess of Aveiro (1676 and 1689)." Philippine Studies 26 (1978): 35-50.

Bourdieu, Pierre. Esquisse d'une théorie de la pratique. Paris: Éditions Droz, 1972.

Broggio, Paolo. Evangelizzare il mondo: Le missioni della Compagnia di Gesù tra Europa e America (secoli XVI-XVIII). Rome: Carocci Editore, 2004.

Brunal-Perry, Omaira. "Las islas Marianas enclave estratégico en el comercio entre México y Filipinas." In España y el Pacífico: Legazpi, edited by Leoncio Cabrero, 1:543-56. Madrid: Sociedad Estatal de Conmemoraciones Culturales, 2004.

Brunal-Perry, Omaira. "La legislación de Ultramar y la administración de las Marianas: Transiciones y legados.” In Imperios y naciones en el Pacífico: Vol. II; Colonialismo e identidad nacional en Filipinas y Micronesia, edited by María Dolores Elizalde, Josep M. Fradera, and Luis Alonso, 395-406. Madrid: cs IC, 2001. 
Campanella, Tommaso. La monarquía hispánica. Translated by Primitivo Mariño. Madrid: Centro de Estudios Constitucionales, 1982.

Cañeque, Alejandro. The King's Living Image: The Culture and Politics of Viceregal Power in Colonial Mexico. New York: Routledge, 2004.

Cañizares-Esguerra, Jorge. Puritan Conquistadors: Iberianizing the Atlantic, 1550-1700. Stanford: Stanford University Press, 2006.

Cantova, Juan Antonio, S.J. “Descubrimiento y descripción de las islas de los Garbanzos (o Carolinas)." Boletín de la Sociedad Geográfica de Madrid 10 (1881): 263-79.

Casanova, José. "The Jesuits through the Prism of Globalization, Globalization through a Jesuit Prism." In The Jesuits and Globalization: Historical Legacies and Contemporary Challenges, edited by Thomas Banchoff and José Casanova, 261-86. Washington, DC: Georgetown University Press, 2016.

Catalogus Provinciae Baeticae. Comillas: Typis Privatis, 1926.

Catto, Michela, and Guido Mongini. "Missioni e globalizzazioni: L'adattamento come identità della Compagnia di Gesù." In Evangelizzazione e globalizzazione: Le missioni gesuitiche nell'età moderna tra storia e storiografia, edited by Michela Catto, Guido Mongini, and Silvia Mostaccio, 1-16. Rome: Società editrice Dante Alighieri, 2010.

Châtellier, Louis. "Conclusions." In Missions religieuses modernes: "Notre lieu est le monde", edited by Pierre-Antoine Fabre and Bernard Vincent, 381-87. Rome: École Française de Rome, 2007.

Chirino, Pedro, S.J. Història de la província de Filipines de la Companyia de Jesús (15811606). Edited by Jaume Górriz. Barcelona: Editorial Pòrtic, 2000 [1635].

Clossey, Luke. Salvation and Globalization in the Early Jesuit Mission. Cambridge: Cambridge University Press, 2008.

Coello de la Rosa, Alexandre. Jesuits at the Margins: Missions and Missionaries in the Marianas (1668-1769). London: Routledge, 2016.

Coello de la Rosa, Alexandre. "Políticas geo-estratégicas y misionales en el sur de Filipinas: El caso de Mindanao y Joló (siglo XVIII).” Revista de Indias, forthcoming, 2019.

Coello de la Rosa, Alexandre. "Redes misionales y geo-estratégicas en Asia-Pacífico: El caso de Mindanao y Joló (siglos XVII-XVIII)." In Espacios misionales en diálogo con la globalidad: Iberoamérica, edited by Maria Laura Salinas and Lia Renata Quarleri, 23-47. Resistencia, Argentina: Contexto, 2016.

Coello de la Rosa, Alexandre, Javier Burrieza, and Doris Moreno. Jesuitas e imperios de ultramar (siglos XVI-XX). Madrid: Sílex, 2012.

Colín-Pastells, Francisco. Labor evangélica de los obreros de la Compañía de Jesús en las Islas Filipinas: Nueva edición ilustrada con copia de notas y documentos para la crítica de la historia general de la soberanía de España en Filipinas por el padre Pablo Pastells, S.J. 3 Vols. Barcelona: Imprenta y Litografía de Henrich y Cia., 1904 [1656]. 
Combés, Francisco, S.J. Historia de Mindanao y Joló. Madrid: Viuda de M. Minuesa de los Ríos, 1897 [1667].

Corpuz, Onofre D. The Bureaucracy in the Philippines. Manila: Institute of Public Administration and University of the Philippines, 1957.

Covarrubias, Sebastián de. Tesoro de la lengua castellana o española. Madrid: Turner, 1979 [1611].

Cummins, James S. "Palafox, China, and the Chinese Rites Controversy." Revista de historia de América $5^{2}$ (1961): 395-427.

Cunningham, Charles Henry. The Audiencia in the Spanish Colonies as Illustrated by the Audiencia de Manila (1583-180o). Berkeley: University of California Press, 1919.

Cushner, Nicholas. Spain in the Philippines: From Conquest to Revolution. Quezon City, Philippines: Institute of Philippine Culture, 1971.

Davin, Diego, trans. Cartas edificantes, y curiosas escritas de las misiones extranjeras, y de Levante, por algunos misioneros de la Compañía de Jesús. Vol. 7. Madrid: Imprenta de la Viuda de Manuel Fernández, 1755.

Davin, Diego, trans. Cartas edificantes, y curiosas escritas de las misiones extranjeras, y de Levante, por algunos misioneros de la Compañía de Jesús. Vol.11. Madrid: Imprenta de la Viuda de Manuel Fernández, $175^{6}$.

De Castelnau-L'Estoile, Charlotte. Les ouvriers d'une vigne stérile: Les jésuites et la conversion des Indiens du Brésil, 1580-1620. Paris: Centre Culturel Calouste Gulbenkian, 2000.

De Castelnau-L'Estoile, Charlotte, Marie-Lucie Copete, Aliocha Maldavsky, and Ines G. Županov, eds. Missions d'évangélisation et circulation des savoirs, XVIé-XVIIIé siècle. Madrid: Casa de Velázquez, 2011.

De Castelnau-L'Estoile, Charlotte, and François Regourd, eds. Connaissances et pouvoirs: Les espaces impériaux (XVI $-X V I I I^{e}$ siècles) France, Espagne, Portugal. Pessac: Presses Universitaires de Bordeaux, 2005.

De la Barras de Aragón, Francisco. "Las islas Palaos." Anuario de estudios americanos 3 (1946): 1081-89.

De la Costa, Horacio, S.J. The Jesuits in the Philippines, 1581-1768. Cambridge, MA: Harvard University Press, 1989 [1961].

De la Puente Brunke, José. "Codicia y bien público: Los ministros de la audiencia en la Lima seiscentista." Revista de Indias 66, no. 236 (2006): 133-48.

Del Pilar i Gatmaitan, Marcelo H. La frailocracia filipina. Barcelona: Imprenta Ibérica de F. Fossas, 1889.

Del Priore, Maritza R. "Education on Guam during the Spanish Administration from 1668 to 1899 ." PhD diss., University of Southern California, 1986.

Del Valle, Teresa. "Approaching Missionary Activity in Micronesia as a Genderized Phenomenon." In Micronesia: Visiones desde Europa, edited by Beatriz Moral, 95113. Madrid: Asociación Española de Estudios de Pacífico \& Ediciones Gondo, 2004. 
Delgadillo, Yolanda, Thomas B. McGrath, S.J., and Felicia Plaza, eds. Spanish Forts of Guam. Guam: Micronesian Area Research Center (MARC), 1979.

Delgado, Josep María. "Caminando por la senda del atraso: Reformismo borbónico, cambio institucional y divergencia europea de España en la baja Edad moderna." In De Tartessos a Manila: Siete estudios coloniales y postcoloniales, edited by Gloria Cano and Ana Delgado, 171-208. Valencia: Publicacions de la Universitat de València, 2008.

Delgado, Josep María. "Filipinas en transición (1850-1950)." In Filipinas, un país entre dos imperios, edited by María Dolores Elizalde and Josep María Delgado, 27-47. Barcelona: Bellaterra, 2011.

Delgado, Juan José. Historia general sacroprofana, política y religiosa de las islas del Poniente llamadas Filipinas. Manila: El Eco de Filipinas, 1892 [1751].

Descalzo Yuste, Eduardo. "Las crónicas oficiales de la Compañía de Jesús en Filipinas en el siglo XVII." In Iglesia memorable: Crónicas, historias, escritos [...] a mayor gloria: Siglos XVI-XVIII, edited by Ángela Atienza López, 275-98. Madrid, Sílex, 2012.

Diaz, Jonathan Blas. Towards a Theology of the Chamoru: Struggle and Liberation in Oceania. Quezon City: Claretian Publications, 2010.

Diaz, Vicente M. “Grounding Flux in Guam's Cultural History." In Work in Flux, edited by Emma Greenwood, Klaus Neumann, and Andrew Sartori, 159-71. Parkville, Melbourne: University of Melbourne History Department, 1995.

Diaz, Vicente M. Repositioning the Missionary: Rewriting the Histories of Colonialism, Native Catholicism, and Indigeneity in Guam. Honolulu: University of Hawai'i Press, 2010.

Diaz, Vicente M. "Simply Chamorro: Telling Tales of Demise and Survival in Guam." In Voyaging through the Contemporary Pacific, edited by David Hanlon and Geoffrey M. White, 141-70. Lanham: Rowman \& Littlefield, 2000.

Díaz-Trechuelo López Spínola, Ma Lourdes. “Filipinas en el siglo de la Ilustración.” In Historia general de Filipinas, edited by Leoncio Cabrero, 249-92. Madrid: Ediciones de Cultura Hispánica, 2000.

Driver, Marjorie G. Cross, Sword and Silver: The Nascent Spanish Colony in the Mariana Islands. Guam: Micronesian Area Research Center and University of Guam, 1987.

Driver, Marjorie G. "Notes and Documents: Quiroga's Letter to King Philip V, 26 May 1720." Journal of Pacific History 27, no. 1 (1992): 98-106.

Driver, Marjorie G. El Palacio: The Spanish Palace in Agaña; A Chronology of Men and Events, 1668-1899. Guam: Micronesian Area Research Center and University of Guam, 1984.

Driver, Marjorie G. The Spanish Governors of the Mariana Islands: Notes on Their Activities and the Saga of the Palacio; Their Residence and the Seat of Colonial Government in Agaña, Guam. Guam: Richard F. Taitano and Micronesian Area Research Center, 2005. 
Duran, Norma, Retórica de la santidad: Renuncia, culpa y subjetividad en un caso novohispano. México, DF: Universidad Iberoamericana, 2008.

Egea López, Antonio. "Las islas Marianas, provincia Española: Una introducción a su estudio." In España y el Pacífico, edited by Florentino Rodao, 153-67. Madrid: AECI and AEEP, 1989.

Egido, Teófanes. "El regalismo y las relaciones Iglesia-Estado en el siglo XVIII." In Historia de la Iglesia en España, edited by Ricardo García Villoslada, 125-49. Madrid: BAC, 1979.

Elizalde, María Dolores. "The Philippines at the End of the Century: Images and Reality." In More Hispanic Than We Admit: Insights into Philippine Cultural History, edited by Glòria Cano, 265-300. Quezon City, Philippines: Vibal Foundation, 2014.

Elliott, John H. Empires of the Atlantic World: Britain and Spain in America, 1492-1830. New Haven: Yale University Press, 2007.

Elliott, John H. España, Europa y el mundo de ultramar (1500-180o). Madrid: Taurus, 2009 .

Farrell, Don A. History of the Mariana Islands to Partition. Saipan: Public School System of the Northern Mariana Islands, 1991.

Farrell, Don A. "The Partition of the Marianas: A Diplomatic History, 1898-1919." ISLA: A Journal of Micronesian Studies 2 (1994): 273-301.

Farrell, Don A. Rota. Tinian: Micronesian Productions, CNMI, 2004.

Fernández Albaladejo, Pablo. Materia de España: Cultura política e identidad en la España moderna. Madrid: Marcial Pons Historia, 2007.

Garavaglia, Juan Carlos. Construir el estado, inventar la nación: El Río de la Plata, siglos XVIII-XIX. Madrid: Prometeo Libros, 2007.

Garavaglia, Juan Carlos. "El teatro del poder: Ceremonias, tensiones y conflictos en el estado colonial." Boletín del Instituto de Historia Argentina y Americana "Dr. Emilio Ravignani" 14 (1996): 7-30.

García de los Arcos, María Fernanda. Estado y clero en las Filipinas del siglo XVIII. México, DF: Universidad Autónoma Metropolitana/Iztapalapa, 1988.

García de los Arcos, María Fernanda. Forzados y reclutas: Los criollos novohispanos en Asia, 1756-1808. Mexico City: Potrerillos Editores, 1996.

Garrett, John. Where Nets Were Cast: Christianity in Oceania since World War II. Suva: Institute of Pacific Studies, University of the South Pacific, 1997.

Giménez, Enrique. "La devoción a la Madre Santísima de la Luz: Un aspecto de la represión del jesuitismo en la España de Carlos III." In Expulsión y exilio de los jesuitas españoles, edited by Enrique Giménez, 213-28. Alicante: Universidad de Alicante, 1997.

Gómez, Fernando. "Experimentación social en los albores coloniales de la modernidad: El deseo utópico-reformista de Vasco de Quiroga (1470-1565)." Boletín americanista 50 (2000): 101-21. 
Gonzalbo Aizpuru, Pilar. "Las devociones marianas en la vieja provincia de la Compañía de Jesús.” In Manifestaciones religiosas en el mundo colonial americano, vol. 2, Mujeres, instituciones y culto a María, edited by Clara García Ayluardo and Manuel Ramos Medina, 257-81. México, DF: INAH, Universidad Iberoamericana, and Condumex, 1997.

González Enciso, Agustín. "Del rey ausente al rey distante." In Imagen del rey, imagen de los reinos: Las ceremonias públicas en la España Moderna (1500-1814), edited by Agustín González Enciso and Jesús María Usunáriz Garayoa, 2-19. Pamplona: EUNSA, 1999 .

Górriz Abella, Jaume. Filipinas antes de Filipinas: El archipiélago de San Lázaro en el siglo XVI. Madrid, Polifemo, 2010.

Gutiérrez, Lucio. "The Formative Years of the Archdiocese of Manila (1565-1850)." Philippiniana sacra 46, no. 137 (2011): 453-80.

Gutiérrez, Lucio. Historia de la iglesia en Filipinas. Madrid: Fundación Mapfre América, 1992.

Harris, Steven J. "Mapping Jesuit Science: The Role of Travel in the Geography of Knowledge." In The Jesuits: Cultures, Sciences, and the Arts, 1540-1773, edited by John W. O'Malley, S.J., Gauvin Alexander Bailey, Steven J. Harris, and T. Frank Kennedy, 1:212-40. Toronto: University of Toronto Press, 2000 [1999].

Hering Torres, Max. “Introducción." In Cuerpos anómalos, edited by Max Hering Torres, 13-28. Bogotá: Universidad Nacional de Colombia, 2008.

Hezel, Francis X., S.J. "Catholic Church in Micronesia: Chuuk." 2003. http://www .micsem.org/pubs/books/catholic/chuuk/index.htm (accessed December 11, 2018).

Hezel, Francis X., S.J. The Catholic Church in Micronesia: HistoricalEssays on the Catholic Church in the Caroline-Marshall Islands. Chicago: Loyola University Press, 1991.

Hezel, Francis X., S.J. "Catholic Church in Micronesia: Marshalls." 2003. http://www .micsem.org/pubs/books/catholic/marshalls/index.htm?PHPSESSID=7c2ff85adb57 66a972c7f2f 21cf4feo5 (accessed December 11, 2018).

Hezel, Francis X., S.J. "Catholic Church in Micronesia: Palau." 2003. http://www .micsem.org/pubs/books/catholic/palau/index.htm (accessed December 11, 2018).

Hezel, Francis X., S.J. “Catholic Church in Micronesia: Pohnpei.” 2003. http://www.mic sem.org/pubs/books/catholic/pohnpei/index.htm (accessed December 11, 2018).

Hezel, Francis X., S.J. “The Catholic Church in Yap." 2003. http://www.micsem.org/ pubs/books/catholic/yap/index.htm (accessed December 11, 2018).

Hezel, Francis X., S.J. "Catholic Missions in the Carolines and Marshall Islands." Journal of Pacific History 5 (1970): 213-27. http://www.micsem.org/pubs/articles/religion/ frames/cathmissionsfr.htm (accessed December 11, 2018).

Hezel, Francis X., S.J. The First Taint of Civilization: A History of the Caroline and Marshall Islands in Pre-colonial Days, 1521-1885. Honolulu: University of Hawai'i Press, 1983. 
Hezel, Francis X., S.J. From Conquest to Colonization: Spain in the Mariana Islands, 1690 to 1740. Saipan: Mariana Islands Division of Historic Preservation, 1989.

Hezel, Francis X., S.J. "Jesuit Martyrs in Micronesia." Micronesian Seminar, 1983. http://www.micsem.org/pubs/articles/religion/frames/jesmartfr.htm (accessed December 11, 2018).

Hezel, Francis X., S.J. Strangers in Their Own Land: A Century of Colonial Rule in the Caroline and Marshall Islands. Honolulu: University of Hawai'i Press, 2003.

Hezel, Francis X., S.J., and Francisco Delgado, "Santiago López de Rego Labarta." In Diccionario histórico de la Compañía de Jesús: Biográfico-temático, edited by Charles E. O'Neill and Joaquín María Domínguez, S.J., 3:2417-18. Madrid: Institutum Historicum S.I., 2001.

Hezel, Francis X., S.J., and María Teresa del Valle. "Early European Contacts with the Western Carolines: 1525-1750." Journal of Pacific History 7, no. 1 (1972): 26-44.

Hidalgo Nuchera, Patricio. La recta administración: Primeros tiempos de la colonización hispana en Filipinas. Madrid: Polifemo, 2001.

Hidalgo Nuchera, Patricio, ed. Redescubrimiento de las islas Palaos. Madrid: Miraguano and Polifemo, 1993.

Hill, Ruth A. "Conquista y modernidad, 1700-1766: Un enfoque transatlántico." In Fénix de España: Modernidad y cultura propia en la España del siglo XVIII (17371766), edited by Pablo Fernández Albaladejo, 52-72. Madrid: Marcial Pons Historia, Universidad Autónoma de Madrid, and Universitat d'Alacant \& Casa Velázquez, 2006.

Höpfl, Harro. Jesuit Political Thought: The Society of Jesus and the State, c.1540-1630. Cambridge: Cambridge University Press, 2004.

Imbruglia, Girolamo. L'invenzione del Paraguay. Naples: Bibliopolis, 1983.

Imbruglia, Girolamo. "A Peculiar Idea of Empire: Missions and Missionaries of the Society of Jesus in Early Modern History." In Jesuit Accounts of the Colonial Americas: Intercultural Transfers, Intellectual Disputes, and Textualities, edited by Marc André Bernier, Clorinda Donato, and Hans-Jürgen Lüsebrink, 21-49. Toronto: University of Toronto Press, 2017.

Javellana, René B., S.J. "Historiography of the Philippine Province." In Jesuit Historiography Online, edited by Robert Aleksander Maryks, 2016. http://dx.doi .org/10.1163/2468-7723_jho_COM_192583 (accessed December 11, 2018).

Javellana, René B., S.J. “The Jesuits and the Indigenous Peoples of the Philippines.” In The Jesuits: Cultures, Sciences, and the Arts, 1540-1773, edited by John W. O'Malley, S.J., Gauvin Alexander Bailey, Steven J. Harris, and T. Frank Kennedy, 1:418-38. Toronto: University of Toronto Press, 2000 [1999].

Jorgensen, Marilyn Anne. "Expressive Manifestations of Santa Marian Camalin as Key Symbol in Guamanian Culture." PhD diss., University of Texas, Austin, 1984. 
Kagan, Richard L. Urban Images of the Spanish World, 1493-1793. New Haven: Yale University Press, 2000.

Kossok, Manfred. La colonització española d'Amèrica: Estudis comparatius. Barcelona: Avenç and Sociedad Catalana d'Estudis Històrics, 1991.

Krippner-Martínez, James. Rereading the Conquest: Power, Politics, and the History of the Early Colonial Michoacán, Mexico, 1521-1565. University Park, PA: Pennsylvania State University Press, 2001.

LaFeber, Walter. The New Empire: An Interpretation of American Expansion, 1860-1898. Ithaca: Cornell University Press, 1998 [1963].

Lane, Kris. Pillaging the Empire: Piracy in the Americas, 1500-1750. New York: Routledge, 1998.

Lee, Wayne E. Empires and Indigenes: Intercultural Alliance, Imperial Expansion, and Warfare in the Early Modern World. New York and London: New York University Press, 2011.

Lévesque, Rodrigue. History of Micronesia: A Collection of Source Documents. Vols. 1-13. Quebec: Lévesque Publications, 1992.

Lisón Tolosana, Carmelo. La imagen del rey (Monarquía, realeza y poder ritual en la Casa de los Austrias). Madrid: Espasa Calpe, 1992.

López, Roberto J. "Ceremonia y poder en el Antiguo Régimen: Algunas reflexiones sobre fuentes y perspectivas de análisis." In Imagen del rey, imagen de los reinos: Las ceremonias públicas en la España Moderna (1500-1814), edited by Agustín González Enciso and Jesús María Usunáriz Garayoa, 19-61. Pamplona: EUNSA, 1999.

Lorenzo García, Santiago. La expulsión de los jesuitas de Filipinas. Alicante: Universidad de Alicante, 1999.

Lorenzo García, Santiago. "La expulsión de jesuitas filipinos: Un ejemplo de disputa por el poder político." In Expulsión y exilio de los jesuitas españoles, edited by Enrique Giménez, 161-8o. Alicante: Universidad de Alicante, 1997.

Maldavsky, Aliocha. "Jesuits in Ibero-America: Missions and Colonial Societies." In The Jesuits and Globalization: Historical Legacies and Contemporary Challenges, edited by Thomas Banchoff and José Casanova, 92-110. Washington, DC: Georgetown University Press, 2016.

Maldavsky, Aliocha. Vocaciones inciertas: Misión y misioneros en la provincia jesuita del Perú de los siglos XVI y XVII. Seville: cSIC, 2012.

Manchado, Marta María, ed. Tiempos de turbación y mudanza: La iglesia en Filipinas tras la expulsión de los jesuitas. Córdoba: Muñoz Moya, 2002.

Maravall, José Antonio. La cultura del barroco: Análisis de una estructura histórica. Madrid: Ariel, 1975. 
Maravall, José Antonio. “Teatro, fiesta e ideología en el barroco." In Teatro y fiesta en el barroco: España e Iberoamérica, edited by José María Díez Borque, 71-95, Barcelona: Serbal, 1986.

Martínez, Francisco. "Las congregaciones marianas de la Compañía de Jesús y su contribución a la práctica de la caridad (siglos XVI-XVIII)." Revista de historia moderna 21 (2003): 211-38.

Martínez Cuesta, Ángel, O.A.R. Historia de los agustinos recoletos, vol. 1: Desde los orígenes hasta el siglo XIX. Madrid: Editorial Avgustinvs, 1995 .

Martínez-Serna, José Gabriel. "Procurators and the Making of the Jesuits' Atlantic Network." In Soundings in Atlantic History: Latent Structures and Intellectual Currents, 1500-1830, edited by Bernard Bailyn and Patricia L. Denault, 181-209. Cambridge: Cambridge University Press, 2009.

Matsuda, Matt K. "The Pacific." AHR Forum: The American Historical Review 111, no. 3 (2006): $75^{8-80 .}$

Mawson, Stephanie. "Unruly Plebeians and the Forzado system: Convict Transportation between New Spain and the Philippines during the Seventeenth Century." Revista de Indias 73, no. 259 (2013): 693-730.

Mehl [see Saint Clair Segurado], Eva Maria. Forced Migration in the Spanish Pacific World: From Mexico to the Philippines, 1765-1811. Cambridge: Cambridge University Press, 2016.

Mendieta, Jerónimo de, O.F.M. Historia eclesiástica indiana. Edited by Joaquín García Icazbalceta. México, DF: Antigua Librería, 1870.

Mendizábal, Rufo, S.J. Catalogus defunctorum in renata Societate Iesu ab a. 1814 ad a. 1970. Rome: Curiam P. Gen., 1972.

Mínguez Cornelles, Víctor. Los reyes distantes: Imágenes del poder en el México virreinal. Castelló de la Plana: Publicacions de la Universitat Jaume I, 1995.

Molina, Luis de. Concordia liberi arbitrii cum gratice donis, diuina prcescientia, prouidentia, prcedestinatione, et reprobatione ad nonnullos primce partis Diui Thomce articulos. Lisbon, 1588.

Mondragón Pérez-Grovas, Carlos. "Reflexiones historiográficas en torno a las percepciones oceánicas durante los primeros encuentros entre europeos y melanesios en el Pacífico." In Un océano de intercambios: Hispanoasia (1521-1898); Un homenaje al profesor Leoncio Cabrero Fernández, edited by Miguel Luque Talaván and Marta M. Manchado López, 1:81-99. Madrid: Agencia Española de Cooperación Internacional, 2008.

Morales, Luis de, S.J., and Charles Le Gobien, S.J. History of the Mariana Islands. Edited by Alexandre Coello de la Rosa. Mangilao, Guam: University of Guam Press, 2016.

Murillo Velarde, Pedro. Carta hydrographica y chorographica de las Yslas Filipinas. Manila, 1734. Biblioteca Nacional, GM/M.XLV no. 31. 
Murillo Velarde, Pedro. Historia de la provincia de Filipinas de la Compañía de Jesús: Segunda parte que comprende los progresos de esta provincia desde el año de 1616 hasta el de 1716. Manila: Imprenta de Nicolás de la Cruz Bagay, 1749.

Nebgen, Christoph. Missionarsberufungen nach Übersee in drei deutschen Provinzen der Gesellschaft Jesu im 17. und 18. Jahrhundert. Regensburg: Schnell \& Steiner, 2007.

Ollé, Manel. "El Mediterráneo del mar de la Cina: Las dinámicas históricas de Asia oriental y la formación del modelo colonial filipino." In Imperios y naciones en el Pacífico, vol. 1, Colonialismo e identidad nacional en Filipinas y Micronesia, edited by María Dolores Elizalde Pérez-Grueso, Josep María Fradera, and Luis Alonso Álvarez, 59-72. Madrid: CSIC, 2001.

O’Neill, Charles E., and Joaquín María Domínguez, S.J., eds. Diccionario histórico de la Compañía de Jesús: Biográfico-temático. Madrid: Institutum Historicum S.I., 2001.

Osorio, Alejandra. "The King in Lima: Simulacra, Ritual, and Rule in SeventeenthCentury Peru." Hispanic American Historical Review 84, no. 3 (2004): 447-74.

Osorio, Alejandra. El rey en Lima: El simulacro realy el ejercicio del poder en la Lima del diecisiete. Lima: Instituto de Estudios Peruanos and Documentos de Trabajo, 2004.

Pagden, Anthony. "Cosmopolitismo, patriotismo, nacionalismo: ¿Qué camino hacia una Europa ilustrada?" Pedralbes 34 (2014): 11-35.

Parker, Charles H. Global Interactions in the Early Modern Age, 1400-180o. New York: Cambridge University Press, 2010.

Pastor, Beatriz. El jardín y el peregrino: El pensamiento utópico en América Latina (14921695). México, DF: Universidad Nacional Autónoma de México, 1999.

Peralta Ruiz, Víctor. Patrones, clientes y amigos: El poder burocrático indiano en la España del siglo XVIII. Madrid: CsIC, 2006.

Phelan, John Leddy. The Hispanization of the Philippines: Spanish Aims and Filipino Responses, 1565-170o. Madison, WI: University of Wisconsin Press, 1967 [1959].

Pietschmann, Horst. "Burocracia y corrupción en Hispanoamérica colonial: Una aproximación tentativa." Nova Americana 5 (1982): 11-37.

Pratt, Mary Louise. Imperial Eyes: Travel Writing and Transculturation. London: Routledge, 1997 [1992].

Prieto Lucena, Ana María. El contacto hispano-indígena en Filipinas. Córdoba: Servicio de Publicaciones de la Universidad de Córdoba, 1993.

Prosperi, Adriano. "L'Europa cristiana e il mondo: Alle origini dellidea di missione." Dimensioni e problema della ricerca storica 2 (1992): 189-220.

Quimby, Frank. “Islands in the Stream of Empire: Spain's 'Reformed' Imperial Policy and First Proposals to Colonize the Mariana Islands, $1565^{-1569 . " ~ P a p e r ~ p r e s e n t e d ~ a t ~}$ the First Marianas History Conference, "One Archipelago, Many Stories," 2012.

Reed, Robert R. Colonial Manila: The Context of Hispanic Urbanism and Process of Morphogenesis. Berkeley: University of California Press, 1978. 
Reichert, Rafal. "La transcripción del manuscrito de fray Ignacio Muñoz sobre el proyecto de manutención y extensión de la fe católica en las islas Marianas, y del descubrimiento y la conquista de las islas Salomón, siglo XVII." Estudios de historia novohispana 51 (2014): 133-63.

Ricci, Matteo. Dieci capitoli di un uomo strano. Edited by Filippo Mignini and Wang Suna. Macerata: Quodlibet, 2010.

Rodríguez García, Vicente. El gobierno de don Gaspar Antonio de la Torre y Ayala en las islas Filipinas. Granada: Universidad de Granada, 1976.

Rogers, Robert F. Destiny's Landfall: A History of Guam. Honolulu: Hawai'i University Press, 1995 .

Ross, Andrew C. "Alessandro Valignano: The Jesuits and Culture in the East." In The Jesuits: Cultures, Sciences, and the Arts, 1540-1773, ed. John W. O'Malley, S.J., Gauvin Alexander Bailey, Steven J. Harris, and T. Frank Kennedy, 1:336-51. Toronto: University of Toronto Press, 2000 [1999].

Rubiés, Joan-Pau. "The Concept of Cultural Dialogue and the Jesuit Method of Accommodation: Between Idolatry and Civilization." Archivum historicum Societatis Iesu 74, no. 147 (2005): 237-80.

Rubiés, Joan-Pau. "The Concept of Gentile Civilization in Missionary Discourse and Its European Reception." In Missions d'évangélisation et circulation des savoirs, XVI ${ }^{-}$ XVIII ${ }^{e}$ siècle, edited by Charlotte de Castelnau-L'Estoile, and Aliocha Maldavsky, 289-328. Madrid: Casa de Velázquez, 2011.

Rubiés, Joan-Pau. "Missionary Encounters in China and Tibet: From Matteo Ricci to Ippolito Desideri." History of Religions 52, no. 3 (2013): 267-82.

Saint Clair Segurado [see Mehl], Eva María. "Las misiones jesuíticas del Extremo Oriente en los dictámenes de los obispos españoles (1769-1770)." Revista de historia moderna 18 (2000): 341-64.

Saint Clair Segurado [see Mehl], Eva María. "El obispo Palafox y la cuestión de los ritos chinos en el proceso de extinción de la Compañía de Jesús." Studia historica: Historia moderna 22 (2000): 145-70.

Sánchez-Gómez, Luis Ángel. "Las elites nativas y la construcción colonial de Filipinas (1565-1789)." In Las relaciones entre España y Filipinas: Siglos XVI-XX, edited by María Dolores Elizalde Pérez-Grueso, 37-70. Madrid: csic, 2004.

Schmidt, Peer. La monarquía universal española y América: La imagen del imperio español en la Guerra de los Treinta Años (1618-1648). México, DF: Fondo de Cultura Económica, 2012.

Shell, Richard J. Proas in the Marianas (1668-1742). Mangilao, Guam: MARC and University of Guam, 1992.

Seoane Pinilla, Julio. La política moral del Rococó: Arte y cultura en los orígenes del mundo moderno. Madrid: Antonio Machado Libros and Colección la Balsa de la Medusa, 2000 . 
Serra de Manresa, Valentí, O.F.M., Cap. "Joaquim M. de Llavaneres i les missions caputxines a les illes Filipines, Carolines i Guam (Anys 1886-1913)." Analecta sacra Tarraconensia 80 (2007): 157-204.

Serra de Manresa, Valentí, O.F.M., Cap. Tres segles de vida missionera: La projecció pastoral "ad gentes" dels framenors caputxins de Catalunya (1680-1989). Barcelona: Edicions de la Facultat de Teologia de Catalunya, 2006.

Serrano, Luis, and Juan Carlos Llorente. Las Carolinas orientales: 189o; La última victoria española en el Pacífico antes del eclipse. Madrid: LSV and JCLL, 2005.

Sinajaña, Eric de, O.M.F. Cap. Historia de la misión de Guam de los capuchinos españoles. Pamplona: Curia Provincial de los Capuchinos, 2001.

Sommervogel, Carlos, S.J., ed. Bibliothèque de la Compagnie de Jésus: Nouvelle édition. Brussels: Oscar Schepens, 1894.

Standaert, Nicolas, S.J. "Jesuit Corporate Culture as Shaped by the Chinese." In The Jesuits: Cultures, Sciences, and the Arts, 1540-1773, edited by John W. O'Malley, S.J., Gauvin Alexander Bailey, Steven J. Harris, and T. Frank Kennedy, 1:352-63. Toronto: University of Toronto Press, 2000 [1999].

Strasser, Ulrike. "Rome to Guam and Back: The Re-formation of Chamorro Identity in a Changing World." Archiv für Reformationsgeschichte/Archive for Reformation History 108, no. 1 (2017): 212-22.

Thomas, Nicholas. Entangled Objects: Exchange, Material Culture, and Colonialism in the Pacific. Cambridge, MA: Harvard University Press, 1991.

Thompson, Laura. "The Native Culture of the Marianas Islands." Bernice P. Bishop Museum Bulletin 185 (1971 [1945]): 3-48.

Tremml-Werner, Birgit. Spain, China, and Japan in Manila, 1571-1644: Local Comparisons and Global Connections. Amsterdam: Amsterdam University Press, 2015.

Tueller, James B. "Los chamorros de Guam y la colonización española: Una tercera etapa (1698-1747)." In Imperios y naciones en el Pacífico: Vol. II; Colonialismo e identidad nacional en Filipinas y Micronesia, edited by María Dolores Elizalde, Josep María Fradera, and Luis Alonso, 385-94. Madrid: cSIC, 2001.

Valignano, Alessandro. Sumario de las cosas de Japón (1583) y Adiciones del Sumario de Japón (1592). Edited by José Luis Álvarez-Taladriz. Monumenta Nipponica Monographs 9. Tokyo: Sophia University, 1954.

Viqueira Albán, Julio Pedro. Propriety and Permissiveness in Bourbon Mexico. Wilmington: SR Books, 1999.

Verlinden, Charles. "Las reducciones y los cambios estructurales en el México hispano (siglos XVI-XVII)." Revista complutense de historia de América 20 (1994): 13-18.

Viveiros de Castro, Eduardo B. A Inconstância da Alma Selvagem e Outros Ensaios de Antropologia. São Paulo: Cosac \& Naify, 2002.

Vizuete Mendoza, J. Carlos. "En las fronteras de la ortodoxia: La devoción a la Virgen de la Luz (Madre Santísima de la Luz) en Nueva España." In Religión y heterodoxias 
en el mundo hispánico: Siglos XIV-XVIII, edited by Ricardo Izquierdo Benito and Fernando Martínez Gil, 255-79. Madrid: Ediciones Sílex, 2011.

Wiecko, Cynthia Ross. "Jesuit Missionaries as Agents of Empire: The SpanishChamorro War and Ecological Effects of Conversion on Guam, 1668-1769." World History Connected 10, no. 3 (2013). http://worldhistoryconnected.press.illinois.edu/ 10.3/forum_wiecko.html (accessed December 11, 2018).

Wilde, Guillermo, ed. Saberes de la conversión: Jesuitas, indígenas e imperios coloniales en las fronteras de la cristiandad. Buenos Aires: Editorial SB, 2011.

Wright, Robert E., O.M.I. "Spanish Missions." Handbook of Texas Online, Texas State Historical Association. http://www.tshaonline.org/handbook/online/articles/itso2 (accessed December 11, 2018).

Yuste López, Carmen. Emporios transpacíficos: Comerciantes mexicanos en Manila (1710-1815). México: Universidad Nacional Autónoma de México, 2007.

Zahino, Luisa, ed. El cardenal Lorenzana y el IV Concilio Provincial Mexicano. México, DF: Universidad Castilla La Mancha and UnAM, 1999.

Županov, Ines G. "Correnti e controcorrenti: La geopolitica gesuita in Asia (XVI secolo)." In I gesuiti ai tempi di Claudio Acquaviva: Strategie politiche, religiose e culturali tra Cinque e Seicento, edited by Paolo Broggio, Francesca Cantù, Pierre-Antoine Fabre, and Antonella Romano, 205-18. Brescia: Morcelliana, 2007. 